\title{
To work or not to work in an extended working life?
}

Factors in working and retirement decisions

\author{
Kerstin Nilsson \\ Faculty of Landscape Planning, Horticulture and Agricultural Science \\ Department of Work Science, Business Economics \\ and Environmental Psychology \\ Alnarp \\ Faculty of Medicine \\ Division of Occupational and Environmental Medicine \\ Lund University
}

Doctoral Thesis

Swedish University of Agricultural Sciences

Alnarp 2013 
Acta Universitatis agriculturae Sueciae 2013:20

ISSN 1652-6880

ISBN 978-91-576-7778-5

(C) 2013 Kerstin Nilsson

Print: SLU Service/Repro, Alnarp 2013 


\title{
To work or not to work in an extended working life?
}

\author{
Factors in working and retirement decisions
}

\begin{abstract}
In most of the industrialised world, the proportion of older and retired people in the population is continuously increasing. This will have budgetary implications for maintaining the welfare state, because the active working section of the population must fund the non-active and old population.
\end{abstract}

Aim: The overall aim of this thesis was to obtain knowledge about older workers' work and life situation in association with their planning and decision to retire from working life.

Method: The thesis includes one qualitative and three quantitative studies conducted in Sweden.

Result: Self-rated health was found to be a better measure than diagnosed disease of whether older workers believed they could work until 65 years or beyond. Health seems not to be a general impediment to working in old age if older workers are satisfied with their work situation and have enough time and opportunities to recover from fatigue. In one of Sweden's most hazardous work environments, older workers were not injured significantly more often than younger workers. Good mental and physical work environment, moderate working pace and working time, and the right competence and possibility for skills development were factors determining whether older workers believed they can extend their working life. Attitude to older workers in the organisation, motivation and work satisfaction were factors determining whether older workers want to extend working life. Health, personal economic incentives, family/leisure pursuits and attitude to pension in society affected both whether people believed they can and wanted to extend their working life.

In their final retirement decision, older workers considered: i) their possibility to balance and adapt functional ageing and health to a sustainable work situation; ii) their economic situation; iii) possibilities for social inclusion and coherence; iv) and possibilities for meaningful activities. Whether these requirements were best fulfilled in or outside working life determined the decision to continue working or to retire.

Conclusion: If it is desirable for society that people will to extend their working life, both the "can work" and the "want to work" factors need to be met. It is important to provide a good fit inside working life. This requires a focus not only on older workers, but also on organisations and managers in order to provide incentives that keep older workers in the work force.

Keywords: ageing, older worker, retirement planning, retirement decision, motivation, meaningful activity, social inclusion, macro, meso, micro, work environment, working life, work ability, work injury, health, public health, diagnosed disease, self-rated health, organisation, basic premises for work, hardware in work, software in work 


\section{Sammanfattning}

Antalet äldre i befolkningen ökar i förhållande till andra åldersgrupper. Detta beskrivs medföra en ekonomisk utmaning för samhället och att fler äldre behöver skjuta upp sin ålderspension.

Avhandlingen bygger på fyra studier med det övergripande syftet att bidra till ökad kunskap om faktorer som medverkar till ett förlängt alternativt förkortat arbetsliv bland personer som är 55 år och äldre.

Resultatet visade att självskattad hälsa var ett bättre mått än diagnostiserad ohälsa för om äldre arbetstagare ansåg sig kunna arbeta till 65 år eller längre. Hälsa var inte ett generellt hinder i arbetslivet om den äldre arbetstagaren upplevde sitt arbete tillfredsställande och att de fick tillräckligt med tid och möjlighet att återhämta sig. Det fanns inte heller några statistiskt signifikanta skillnader angående arbetsskadeincidensen mellan äldre och yngre åldersgrupperna verksamma inom en av Sveriges farligaste arbetsmiljöer, jord- och skogsbruk. God psykisk och fysisk arbetsmiljö, måttligt arbetstempo och lämpliga arbetstider, samt rätt kompetens och möjlighet till kompetensutveckling, var associerat med om äldre arbetstagare ansåg sig kunna arbeta i ett förlängt arbetsliv inom hälso- och sjukvården. Attityd till äldre i organisationen, motivations faktorer samt arbetstillfredsställelse, var associerat med om de äldre ansåg sig vilja arbeta i ett förlängt arbetsliv. Hälsa, ekonomiska incitament, familj, fritidsysselsättningar och attityd till pension i samhället var associerat med om äldre ansåg sig både kunna arbeta och att vilja arbeta i ett förlängt arbetsliv. I det slutliga pensionsbeslutet övervägdes fyra teman: i) möjlighet att balansera och anpassa det funktionella åldrandet och hälsan till arbetssituationen; ii) den ekonomiska situationen; iii) möjlighet till social inkludering i ett positivt sammanhang; iv) möjlighet till meningsfulla aktiviteter. Om dessa teman ansågs bäst i eller utanför arbetslivet var avgörande för beslutet att arbeta eller att gå i ålderspension.

Sammanfattningsvis visar resultaten i denna avhandling att följande tre förutsättningar behövs vara tillfredsställande om samhället vill att fler äldre individer ska arbeta i ett förlängt arbetsliv: i) grundläggande förutsättningar för arbete, dvs. hälsa, ekonomiska incitament och familj och samhällets attityder till ett förlängt arbete; ii) hårdvara i arbetssituationen, dvs. den fysiska och psykiska arbetsmiljön, arbetstakt och arbetstid, kompetens och kunskaper; och iii) mjukvara i arbetssituationen, dvs. attityden från chefer och organisation, motivation och arbetstillfredsställelse. För att skapa dessa förutsättningar är det även viktigt att generera incitament för organisationer, företag och chefer till att kunna och vilja behålla äldre i arbetskraften och medverka till ett hållbart arbetsliv till en hög ålder. 
Author's address:

Kerstin Nilsson,

Department of Work Science, Business Economics and Environmental Psychology,

Swedish University of Agricultural Sciences,

P.O. Box 88,

SE-230 53 Alnarp,

Sweden

E-mail: kerstin.nilsson@ slu.se

$\&$

Kerstin Nilsson,

Occupational and Environmental Medicine (Alwallhuset)

Lund University \& Regional Laboratories Region Skåne

SE-221 85 Lund

Sweden

E-mail: kerstin.nilsson@med.lu.se 

Old age shows the lived life

as evening brief the day

Kerstin Nilsson

Lund, October 2012 


\section{Contents}

List of Publications $\quad 11$

$\begin{array}{ll}\text { Terms and definitions in the thesis } & 13\end{array}$

$\begin{array}{lll}1 & \text { Introduction } & 15\end{array}$

2 Objectives $\quad 19$

$3 \quad$ Background $\quad 21$

3.1 Demographic situation, retirement and ageing 21

3.2 Mind view of the thesis 25

$\begin{array}{ll}3.2 .1 \text { Health } & 26\end{array}$

$\begin{array}{ll}3.2 .2 \text { Economic incentives } & 29\end{array}$

$\begin{array}{ll}\text { 3.2.3 Physical work environment } & 30\end{array}$

3.2.4 Mental work environment $\quad 32$

3.2.5 Work pace and working time 34

3.2.6 Attitude to older workers from managers and in the organisation35

3.2.7 Competence and possibility for skills development 38

3.2.8 Motivation and work satisfaction 40

3.2.9 Family/leisure pursuits and attitude to pension in the surrounding society

$4 \quad$ Materials and Methods $\quad \mathbf{4 5}$

4.1 Design overview $\quad 45$

4.2 Data collection 46

4.3 Sample 49

4.4 Data analysis 51

4.5 Ethical considerations 54

5 Results $\quad \mathbf{5 5}$

5.1 Paper I: Factors influencing whether older workers believe they "can" and "want to" extend their working life. 55

5.2 Paper II: Influence of factors associated with older workers diagnosed disease and self-rated health on retirement planning. 58

5.3 Paper III: Demanding work environment and occupational injuries in old age $\quad 62$

5.4 Paper IV: The decision to continue working or retire early 64 
6 Discussion $\quad 69$

6.1 A model to work or not to work in an extended working life 69

6.2 General discussion 71

6.2.1 Factors influencing whether older workers believe they "can" and "want to" extend their working life. 71

6.2.2 Influence of factors associated with older workers diagnosed disease and self-rated health on retirement planning. $\quad 74$

6.2.3 Demanding work environment and occupational injuries in old age 77

6.2.4 The decision to continue working or retire early 79

6.3 Methodological considerations 83

$\begin{array}{lll}7 & \text { Conclusions } & 87\end{array}$

$\begin{array}{lll}7.1 & \text { Future research } & 89\end{array}$

$\begin{array}{ll}\text { References } & 91\end{array}$

$\begin{array}{ll}\text { Acknowledgments } & 112\end{array}$

8 Appendix $\quad 115$

8.1 Appendix 1. References to the nine areas 117

8.2 Appendix 2. Working life and retirement 121 


\section{List of Publications}

The thesis is based on the following papers, which are referred to by their respective Roman numeral in the text:

I. Nilsson K. Rignell-Hydbom A. Rylander L. 2011. Factors influencing the decision to extend working life or retire. Scandinavian Journal of Work, Environment and Health, 37(6):473-480.

II. Nilsson K. Rignell-Hydbom A. Rylander L. Self-rated health and diagnostic disease associated with early or deferred retirement. (in manuscript).

III. Nilsson K. Pinzke S. Lundqvist P. 2010. Occupational injuries to senior farmers in Sweden. Journal of Agricultural Safety and Health, 16(1):19-29.

IV. Nilsson, K. 2012. Why work beyond 65? Discourse on the decision to continue working or retire early. Nordic Journal of Working Life Studies, 2(3):7-28. ISSN no. 2245-0157.

Papers I, III and IV are reprinted here with the kind permission of the publishers. 


\section{Terms and definitions in the thesis}

Accident

Diagnosed disease

Extended working life

Health

Injury

Mental health

Older worker

Physical health

Pension
A sudden incident that results in bodily injury

Objective ill-health detected by a physician

Working to age 65 and beyond

Health is a wide concept (see some definitions under Health in the Background section). In this thesis health is defined in a holistic way as a state in which an individual is not suffering from disease or hindered from important functions in daily life. An individual with a diagnosed disease can still experience a high self-rated health and vice versa. However, in this thesis there is particular interest in physical and mental health. Paper II also researched two ways to measure health.

Physical or mental damage or harm from accident or illness

Health related to cognitive functions

Occupational workers who are 55 years and older

Health related to physiological and mechanical bodily functions

A monthly payment to someone who is retired from work 
Retirement

Self-rated health

Work

Worker
The state of being retired from a business or occupation permanently or to some degree and starting to get benefit from the social pension insurance system. Excludes disability pensions, private pensions or contractual pensions.

People's own subjective experienced health and wellbeing

Occupational work. Excludes voluntary work or leisure pursuits

Includes both employed and self-employed 


\section{Introduction}

Public health and work environmental research focuses on increasing health among individuals and subgroups in society and creating a sustainable society. One hundred years ago, in 1913, a statutory retirement age was introduced in Sweden. Now, the increasing proportion of elderly in the Swedish population, and also in the entire Western world, is focusing interest on retirement. This doctoral thesis in Public Health and Epidemiology examines important factors in people's decision to extend working life or retire early.

Increased ageing is an outcome of modern development and people live longer because of improved nutrition, sanitation, medical advances, health care, education and economic well-being. Life expectancy at birth was over 80 years in 33 countries in 2011, up from 19 countries in 2005 (UNFPA \& HelpAge International, 2012). In EU-27 countries, the median age of the population was 40.6 in 2009, and it is projected to reach 47.9 years by 2060 (European Commission, 2010). The average age of exit from the labour force in EU-27 was 61.5 years in 2010 and the number of people aged 60 and above in the EU is now rising by more than two million per year, roughly twice the rate observed until about three years ago. By 2014, the working age population (20-64) will start to shrink, as the large cohorts born immediately after World War II retire. The working population is also ageing and the proportion of older workers in employment relative to younger workers is increasing (European Commission, 2010). However, the challenge and opportunity that this demographic shift presents and can bring to society includes a socially and economically active, secure and healthy ageing population (UNFPA \& HelpAge International, 2012). This challenge and opportunity also raises special interest in the working life approach to older workers, in this thesis defined as 55 years of age and 
older, and the question of when it is appropriate to retire for the individual. Retirement planning and factors important to whether older workers believe they can and want to extend their working life are complex, multidisciplinary and involve many different research areas (Feldman \& Beehr, 2011).

Most of the theoretical models that are used in retirement studies are not developed specifically to consider old age retirement but rather economics, organisational and social needs, personal development, wellbeing and health (Beehr, 1986). However, personal factors (such as health and economic well-being) and environmental factors (such as work characteristics and leisure interest) both influence retirement planning and related decisions (Beehr, 1986; Ilmarinen, 2006; Taylor \& Shore, 1995). Some factors seem to "pull" or "push" older workers to leave the workforce, whereas others influence them to stay in the workforce (Beehr, 1986; Cobb-Clark \& Stillman, 2009; Roberts et al., 2010; Stattin, 1998). Ageing and old age retirement from working life is a complex research question and can be studied in three theoretical levels: macro, meso and/or micro level. The overall macro or state/society level includes the structure in society, economic diversity, development, values and attitude in association with older people and ageing (Tornstam, 2011). The macro level also includes when the society wants older people to retire from working life. The meso or group and organisational level includes age management and leadership, how different attitudes in the surrounding environment influence and affect the older person, how individuals influence each other, and group participation (Tornstam, 2011). The meso level also includes organisations dealing with their older workers. The micro or individual level includes how our body and intellect are changed with age, how that influences individuals physically and mentally, and the older person's participation in different activities (Tornstam, 2011). The interest in this thesis is mostly on the micro level perspective and older workers' own attitude and experience of their situation, but also in association with the other levels inside and outside working life.

Different factors influence older workers' retirement planning (see Background below), but previous research has looked at one or a few factors at a time and not as much at the older workers' total life and work situation. Factors influencing individuals' retirement need to be better understand on the individual level if societies want to increase the pension age:

We do not know which factors in the life and work situation determine whether older workers believe they can work, but also whether they want to 
work. If we want to make interventions, promote activities and fit working life better to older workers, it is important to know whether there is a difference between "can" and "want to" extend working life.

Health is used as a predictor of work ability and is important in whether people can be a part of working life. However, we do not know if there is a difference between factors associated with objective, stated diagnosed disease or the older workers' own subjective, stated self-rated health in association with their life and work situation. We also do not know which of these two health verdicts is best associated with whether older workers believe they can continue their working life.

Some occupations are also more physically demanding than others, but we do not know if there are differences in frequency of work accidents and type of injuries between older and younger workers.

Retirement planning and important factors on how to proceed are one side of the coin, but we do not know how and why those who want to go on working or those who leave working life early actually view their retirement decision. 


\section{Objectives}

The overall objective of this thesis was to obtain knowledge about older workers' work situation in association with their planning and decision to retire from working life in Sweden.

The specific objectives were reflected in the following research questions :

- Which factors in the life and work situation of health and medical care personnel aged 55-64 years determine whether they believe they "can work" or "want to work" until 65 years of age or beyond, whereas others think they "cannot" or "do not want to" do so? (Paper I)

- Which factors in the life and work situation of health and medical care personnel aged 55-64 years are most associated with their diagnosed disease and self-rated health? Is there a distinction between statements associated with diagnosed disease and self-rated health? Which health measures are best associated with whether older workers believe they can work until 65 years of age and beyond? (Paper II)

- Do older workers experience more work-related injuries in physically demanding work environments than younger workers? Do some accidents happen more often in the older age group? Which part of the body is most frequently injured and is there a difference in revitalisation between different age groups? (Paper III)

- What are the most important factors determining retirement decisions among people who leave working life before 65 years of age and those working beyond 65 years? (Paper IV) 


\section{Background}

\subsection{Demographic situation, retirement and ageing}

The demographic change in most of the industrial word is continuously increasing the fraction of older people (Bengtsson \& Scott, 2010; Danish Labour Market Commission, 2009; Eurostat, 2010; Giannakouris, 2010; Ilmarinen, 2006; OECD, 2011; SOU, 2012). On average, people nowadays are living longer in retirement than people did two generations ago. More than 33 per cent of men and 38 per cent of women in the EU25 (European Union of 25 member states) will be aged 60 years or above in 2050, up from 18 per cent of men and 24 per cent of women in 2000 (OECD, 2007). The demographic situation is similar in most of the Western world and the predicted figures for 2050 for those aged 60 years and older, of men and women respectively, are: USA 24\% and 28\%; Sweden $28 \%$ and 30\%; Finland 31\% and 35\%; Germany $34 \%$ and $39 \%$ (OECD, 2007).

When the population is ageing, the old age support ratio burden in the society will increase, because the active working part of the population has to fund the non-active and old population. In the countries included in the Organization for Economic Co-operation and Development (OECD), the old age support ratio is estimated to be 2.1 by 2050, compared with 4.9 in 2008 (OECD, 2011). In other words, 2.1 persons in the working population (i.e. aged 20-64 years) will support every person aged 65 years or older in 2050, whereas 4.9 did in 2008. In Sweden the old age support ratio is estimated to decrease from 3.3 in 2008 to 2.2 in 2050 (OECD, 2011). The increasing amount of elderly will also increase the need of health care and strain the pension system. All this will probably have economic and budgetary implications for maintaining the welfare state (Bengtsson \& Scott, 2010; Eurostat, 2010; Danish Labour Market Commission, 2009; SOU, 2012). In some part of the society the attitude is that 
older workers have to retire and give the young and unemployed a chance to enter the workforce. However, that is not a sustainable solution when the society need more working hour in the economy for maintaining the welfare state. Many societies also had to delay the retirement age to manage the burden with increasing amount in the pension system. Therefore many societies will have to motivate people to work until an older age to increasing the number of working hours in the economy (Bengtsson \& Scott, 2010; Eurostat, 2010; Danish Labour Market Commission, 2009; SOU, 2012).

At age 63-65 years, about half the workforce maintains a moderate level of work ability (Härmä, 2011; von Bonsdorff et al., 2011). However, some countries have already decided to increase the retirement age and older workers seem to be a significant public health issue (Jones et al., 2012). Between 1995 and 2010 , the average statutory retirement age increased by 0.5 years among women and 0.8 years among men in the OECD countries (SOU, 2012).

In Sweden, when statutory retirement was introduced in 1913 the retirement age was stated to be 67 years, but the average remaining life expectancy for those who lived to age 65 in 1913 was 13 years for men and 14 years for women. Eighteen per cent of the population was 65 years and older in 2011. At the same time, the mean age was 41 years and the average life expectancy was 79 years for men and 83 years for women. The accounted average remaining life expectancy from 65 years in 2011 was 19 years for men and 21 years for women, and the predicted figures for 2050 are 23 years for men and 24 years for women. The retirement age in Sweden was decreased to 65 years in 1976, but since 2000 it is 67 years. Today the average retirement age is about 65 years in Sweden ${ }^{1}$. However, it is possible to start drawing $25,50,75$ or 100 per

1. In Sweden the average age to start getting old age retirement benefit from the social retirement system in 2011 was 64.6 years of age among men and 64.7 years among women. Average retirement age if also including disability pension after 50 years of age was 63.9 years, and if also including disability pension after 30 years of age 62.5 years (Karlsson \& Olsson, 2011). In 2000 the retirement age for both men and women was about 62 years. In 1970 the retirement age was 66 years for men and 61 years for women. An additional about 80 percent of men 60-64 years was in the work force in 1970, compared with 56 percent in 2000 (Olsson, 2002). However, 80 percent of men and 78 percent of women aged 55-59 years, 67 percent of men and 63 percent of women aged 60-64 years, 24 percent of men and 16 percent of women aged 65-69 years and 8 percent of men and 3 percent of women aged 70-74 years of age were in the workforce in 2010 in Sweden. There were also 4641 men $(0.014 \%)$ and 1627 women $(0.003 \%)$ aged 75 years and older who were still included in the workforce. The professions with the highest average age among women in 2010 were e.g. politicans, public servants, lecturers, and specialist nurses. The 
cent of an occupational pension from 61 years of age since 2000 (RFV, 2004; SOU, 2012). The economic benefits increase if the individual remains in working life, but after 67 years of age it is up to the employer to decide whether they want the individual to continue in work (RFV, 2004). Despite the increased economic benefits of higher pension age nowadays in Sweden, more than 80 per cent still choose to retire at 65 years of age or before (SOU, 2012). If nothing changes, the compensation in the social old age pension system will decrease by $10-15$ per cent by 20 years from now.

In the other Nordic countries, the statutory retirement age is 65 years in Finland, 67 years in Iceland and 67 years in Denmark for those born after 1960 (Folkpensionslag Finland; Nordiska socialförsäkringsportalen; Social pension Denmark). In Norway the retirement age with full economic benefits is 67 years, but the system is flexible and it is possible to have 20-100 per cent pension from 62 to 75 years of age (Arbeidsdepartementet Norway, 2012).

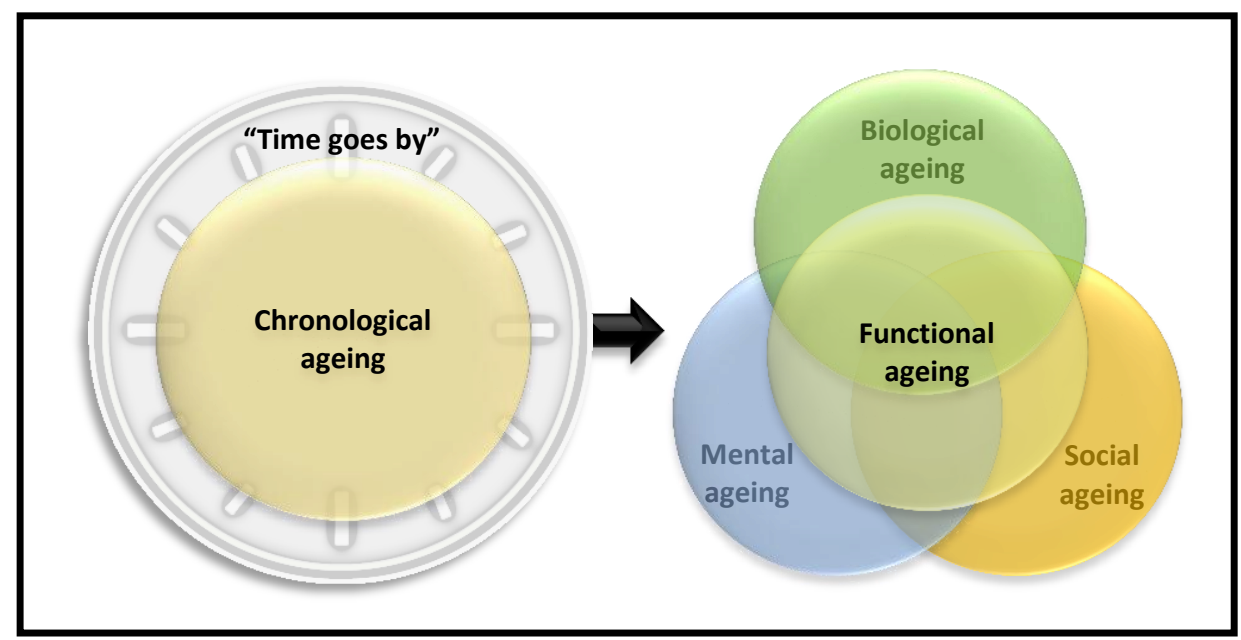

Figure 1. Model of ageing definitions and their relations to each other.

The statutory level of retirement says little about older people's own experience and decision-making on whether they can and want to continue to work. The individual's thoughts and decisions contain content provided

professions with the highest average age among men in 2010 were e.g. politicians, public servants, managers in public service and lecturers (SCB, 2012). 
by cultural and social concepts and values, but people do not uncomplicatedly absorb and live these out in their lives (Burr, 1995). The macro level system of old age retirement regards the individual's chronological age, but people experience their own ageing on a micro level and therefore functional age is of importance in people extending their working life. Some cultures and religious traditions honour older people, e.g. Chinese, Jews and Christians in the past. In other cultures, e.g. among Eskimo and Samer, some altruistic self-killing occurred in olden times when the elderly could not contribute to group welfare or work anymore (Odén, 2012). However, there is no scientific evidence that "ättestupa", i.e. pushing old people over a cliff when they not could contribute to group welfare, ever occurred. The Roman dramaturgist Terentius, who lived 195159 B.C., stated "Senectus ipsa morbus est" - Old age in itself is a disease. However, that is a controversial assumption and cannot be seen as a true hypothesis, because ageing is an effect of social circumstances, life style, injuries, diseases and genetic heritage, which together create what we describe as ageing (Figure 1). Chronological age depends on time going by. Although how long people have lived affects them in common, functional ageing can differ greatly between people in the same chronological stated age. This is because functional age includes: mental ageing, e.g. individual development and cognitional aspects; social ageing, e.g. social inclusion and identity compared with a social situation; but also biological ageing (Erber, 2010; Tornstam, 2011; Hagberg \& Rennemark, 2004). Biological ageing depends on genetic heritage, on the telomere lengths in each 46 chromosome-end inside the cells of our body. However, people's lifestyles, injuries and diseases during their (working) life also affects telomere length (Nawrot et al., 2004; Nowak et al., 2002; Valdes et al., 2005). 


\subsection{Mind view of the thesis}

Most things, thoughts and decisions in our lives are not unified, coherent and one-sided, but seem to be different when viewed through different discursive and contextual lenses. The nature of human beings is such that our thinking processes before decisions involve arguments and weighing up pros and cons (Burr, 1995). For example, even though we can work in an extended working life, it does not mean we want to do it, and vice versa. The mind structure to this thesis therefore started with a model describing different areas of interest in retirement planning and related decision making (Figure 2, see also references in Appendix 1). More detailed descriptions of the areas of interest to people's retirement planning and retirement decision making follow below

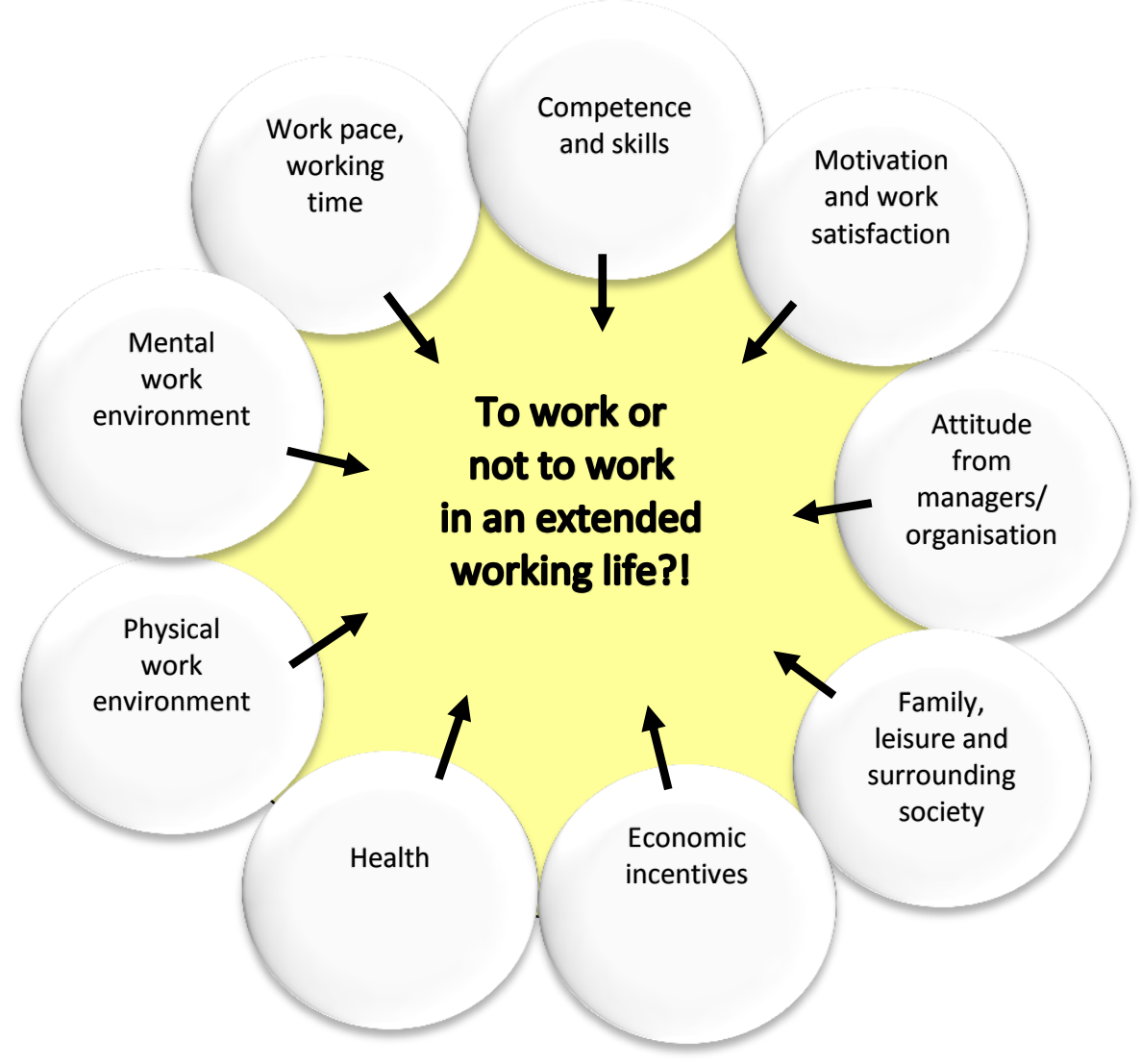

Figure 2. Areas associated with older workers' retirement or extended working life. 


\subsubsection{Health}

What is health? How is my health? Are my health and functions affected by age? Will my health be better or worse if I remain in work? Will my health be better or worse if I retire?

Productivity goes on increasing until people are 50-55 years, but in general only decreases very slightly afterwards (Göbel \& Zwick, 2009). Health is an important factor for productivity, the possibility to be included in the working life, and is also described as an important factor in retirement (Anderson et al., 1986; Beehr, 1986; Bengtsson \& Nilsson, 2004; Bösch-Supan et al., 2009; Cobb-Clark \& Stillman, 2009; Disney \& Tanner, 1999; Forma et al., 2005; Hallsten, 1996; Ilmarinen, 2003; Kilbom \& Torgén, 1996; Månsson \& Råstam, 2001; Nylén \& Torgén, 2002; Park, 2010; Park et al., 2012; Pit et al., 2010; Nilsson, 2005a; 2006; Roberts et al., 2008; Schuring et al., 2011; Saurama, 2004; Seitsamo \& Klockars, 1997; Siegrist et al., 2007; Taylor \& Shore, 1995; von Bonsdorff, 2009; Warr 1994; WHO, 2002). However, one study found limited interventional evidence involving occupational health promotion in retaining older people at work (Crawford, 2011).

Health decreases as people get older, but the variation is huge (Holliday, 2010; Koolhaas et al., 2012; Laslett, 1991; Seitsamo \& Klockars, 1997). Age differences occur in people's anatomy and physiology, as the interaction between brain, sensory organs, locomotive organs and circulatory organs decreases from 40 years of age (Kilbom \& Torgén, 1996). In addition, physiological degeneration contributes to decreases in hearing and eyesight, but also increasing reaction time (Hallsten, 1996). The prevalence of chronic pain seems likewise to increase with age (Hunter, 2001). Health has been called a key determinant of early retirement (Roberts et al., 2010). One reason for older individuals being more likely to suffer decreased health is their longer time of (work) environmental and lifestyle exposure (WHO, 2002). It has also been stated that work-related exhaustion is associated with acceleration of the rate of biological ageing and shortening of telomere length (Ahola et al., 2012). Other studies show that mortality is not dependent on early or later retirement from working life when adjusting for diagnoses (Hult et al., 2010). Another study found it difficult to show whether it was the change in activity following retirement that increased mortality, or whether it was a health-associated selection bias of the early retired (Quaade et al., 2002). On the other hand, one study found that physical functioning declined regardless of whether older civil servants were still working or were retired (Mein et al., 2003). 
Promotion of good health could be an argument to leave working life early (Bengtsson \& Nilsson, 2004; Blakeley \& Ribeiro, 2008). However retirement can be both beneficial and detrimental to the individual's health, increasing health after retirement in some but decreasing it in others (Moen, 1996; Westerlund et al., 2009; Östberg, 1992). Classic work research theory claims that ill-health gives both the individual and the organisation an accepted hideaway from work (Trist \& Bamforth, 1951). However, leaving working life can also be a way to rest, so that the individual does not become worn out prematurely (Trist \& Bamforth, 1951). People who enjoy their work seem to downplay their health problems and work longer, while those who dislike their work exaggerate their health problems and retire earlier (Dwyer \& Mitchell, 1999). On the other hand, health as a predictor of early retirement seems not to be as common in countries with average earlier retirement (Börsch-Supan, 2000; Börsch-Supan et al., 2009). In addition, better environmental circumstances, e.g. life style factors, training and improved (work) environment could promote health and delay functional ageing (Kilbom \& Torgén, 1996). High level of wellbeing, gratification and quality of life seem also to promote the experience of better health among older people (Borglin, 2005; Rennemark, 1999). In all older individuals, but especially those with chronic diseases, a healthy life style with physical, mental and social activities prevents declining health capacity and work ability (Ilmarinen, 2003).

Work and retirement seem to be both beneficial and demanding to health according to the research cited above. What then is health? Health includes e.g. cells, mind and relations to the surrounding environment and society, and has been defined differently throughout history. Hippocrates (460-370 B.C.) described as the father of the art of healing, defined health in a holistic perspective and included wellness in both body and soul. The physician Claudius Galenos (129-200 A.C.), also from Greece, described health as a state in which we do not suffer from illness or are hindered from important functions in our daily life. During the $20^{\text {th }}$ century the medical paradigm took over and diagnosis became more important in health definitions. A biostatistical view of health came to dominate and without an objectively diagnosed disease, no-one could claim to have bad health. On the other hand, with diagnosed disease no one could actually have good self-rated health (Boorse, 1977). This view of health in some way still dominates in the social security and disability retirement system in Sweden (http://www.forsakringskassan.se). The constitution of the World Health Organization (WHO) defines health as "a state of complete physical, mental, and social well-being and not merely the absence of disease or infirmity". The definition has been the subject of 
controversy because of the use of the word "complete" since it entered into force in 1948. However, in the Sundsvall Statement on Supportive Environments for Health WHO stated: "Health itself should be seen as a resource and an essential prerequisite of human life a social development rather than the ultimate aim of life. It is not a fixed end-point, a "product" we can acquire, but rather something ever changing, always in the process of becoming". Health can also be split up and defined in many different parts (Ewles \& Simnett, 1992). Physical health includes physiological and mechanical bodily functions; mental health includes cognitive functions; emotional health includes the possibility to experience and feelings such as fairness, happiness, anger and sorrow; social health includes the possibility to create and handle social relations to others; spiritual health includes life philosophy, cultural principles and peace of mind; and societal health includes the association between a person's health and the surrounding society compared with the environment (Ewles \& Simnett, 1992). Other researchers today still want to define health in a more holistic way, as done by Hippocrates and Galenos, and indicate that even if an individual has a diagnosed disease he or she could still experience high self-rated health and vice versa (Nordenfelt, 1991).

Due to the different definitions, health can also be measured in different ways, e.g. in an objective way as a diagnosis of disease given by a physician or as an individual's subjective experienced self-rated health (Lavesson \& Nilsson, 2011; Nordenfelt, 1991). Seitsamo \& Klockars (1997) described in a follow-up study differences in self-rated and diagnosed disease due to different experiences and expectations regarding health with increased age among older workers. People in their 50s reported a lower self-rated health than their diagnosed disease, but 10 years later the same persons stated a higher self-rated health but more diagnosed disease (Seitsamo \& Klockars, 1997). Self-rated health has in some studies also been found to be a better predictor of disability retirement (Karlsson et al., 2008; Karpansalo et al., 2004; Pietiläinen et al., 2011), whereas the social security system uses diagnosed disease. In addition, some studies have found self-rated health to be a better predictor of mortality than diagnosed disease (Idler \& Benyamini, 1997; Mossey \& Shapir, 1982; Singh-Manoux et al., 2007; Strawbridge \& Wallhagen, 1999). Regarding its complexity, the association between diagnosed and self-rated health in relation to retirement has been found to need further study (Seitsamo \& Klockars, 1997; Singh-Manoux et al., 2007). 


\subsubsection{Economic incentives}

How is my personal economic situation? Can I afford to retire early? Are the economic incentives of an extended working life necessary or a bonus? Are the economic incentives within an extended working life desirable or not worth it?

Social security and pension benefits seem to affect people's decision to retire (Beehr, 1986; Bösch-Supan, 2000; Cobb-Clark \& Stillman, 2009; Coppola \& Benita Wilke, 2010; Diamond, 2008; Doerpinghaus \& Feldman, 2001; Höög \& Stattin, 1995; Karlsson et al., 2008; Nilsson, 2005a; 2006; OECD, 2006; Soidre, 2005; Stattin, 2005; 1998). There are different models that suggest how people forecast their retirement benefit and estimate at what point it is best to retire, but critics note that most people cannot predict those parameters (Hallberg, 2007). However, finances are often used by society to regulate people's retirement planning (Danish Labour Market Commission, 2009; Eurostat, 2010; SOU, 2012). Personal finances and retirement incentives keep employees in the work force through poverty, or pull them into retirement and make it possible to stop working through economic well-being (Beehr, 1986; Bösch-Supan, 2000; Cobb-Clark \& Stillman, 2009; Coppola \& Benita Wilke, 2010; Forma et al., 2005; Höög \& Stattin, 1995; Nilsson, 2005a; 2006; Roberts et al., 2010; Soidrie, 2005; Stattin, 1998; 2005). Socio-economic status also affects the individual's odds of successful ageing (Hank, 2011). Furthermore, some studies show that financial hardship influences the risk of mortality among older adults (Tucker-Seeley et al., 2009). On the other hand, personal economic stability gives better self-rated health, and elderly people of low socio-economic status given an increasing amount of non-contributory pension show an improvement in self-rated health (Brenes-Comacho, 2011).

Economic analysis often considers incentive/disincentive trade-offs such as "pull" factors in the individual level of the social insurance system (Stattin, 2005). One study found that if the benefits programme is equally or more beneficial than work, the individual is voluntarily pulled out of working life (Stattin, 2005). Another study found that workers who disliked their work and were more optimistic in their expectations of enjoying future retirement made greater financial sacrifices to retire early (Bidewell et al., 2006). Income and wealth also seem to influence work and retirement decisions, mostly among men and unmarried women, but not as much among married women (Weaver, 1994). Earlier studies also noted that salary is an important factor in why people work, but it does not increase people's internal motivation to work (Herzberg, 1966; Herzberg et al., 1959; Nilsson, 2011b). On the other hand, many older people combine work and retirement. In Sweden, the proportion of 
people aged 66 years with a salary from work was 36 per cent in 2009, up from 19 per cent in 1997 (Ministry of Health and Social Affairs, 2011). Including the self-employed, the proportion was 41 per cent among those aged 66 years and 21 per cent among those aged 71 years in 2009 (Ministry of Health and Social Affairs, 2011). Self-employed and farmers seem to have specific possibilities to adjust their tasks and productive activities to their functional ageing, which gives them the option to go on and work in paid or unpaid work on their own terms (Nilsson, 2011b). Transfer of firm and property to the next generation also puts self-employees' retirement in a specific situation and they often adjust their retirement to the takeover (Nilsson, 2011b).

Mixed age-working teams are reported to contribute to higher productivity (Göbel \& Zwick, 2010). Despite this, older workers are not likely to return to the work force once they become unemployed (van Ours, 2009). On the other hand, retired persons continue to make economically and socially valuable contributions to society (Dosman et al., 2006). Older retired people often remain engaged in productive activities even when they leave the work force, replacing their paid work with unpaid work, i.e. voluntary work and caring work (Dosman et al., 2006; Nilsson, 2011b). However, people who withdraw from working life and retire may no longer be able to contribute to family finances in the same way, which may lead to loss of status in their own eyes, as well as those of their family and society (Trist \& Bamforth, 1951).

\subsubsection{Physical work environment}

How is my physical work environment? Are there physical demands and injury risks in my work situation? Is my health already affected by demanding physical work situations? Is my physical health and fitness boosted by my physical work environment?

Injury and musculoskeletal and mental disorders could be predictors for early pension (Karlsson et al., 2008). The variation in the most common types of occupations in a country, but also different work circumstances given the same occupations in different countries, partly explains the variation in general retirement age between countries (Sauré \& Zoabi, 2011). Poor physical work environment or ill-suited and demanding work conditions leave people worn out and they leave working life early (Bengtsson \& Nilsson, 2004; Grahn, 2003; Hallsten \& Solem, 1996; Ilmarinen \& Louhevara, 1999; Munnell et al., 2004; Nilsson, 2003a; 2003b; 2005a; 2005b; 2006; OECD, 2006; Pohjonen, 
2001; Seitsamo \& Klockars, 1997; Volkoff, 1998; von Bonsdorff et al., 2009; Warr, 1994). Tests with the work capacity instrument Work Ability Index (WAI) show decreased work capacity with increased age among individuals in physically demanding work environments and those with low control over their work (Pohjonen, 2001). Health problems seem also to be systematically different due to occupation and accumulate over the life time (Gueorguieva et al., 2009). Blue-collar workers with low work ability in midlife have an accelerated decline in health and functioning which remains evident in old age (von Bonsdorff et al., 2011). In addition, there is a disposition among those with only a basic education to remain in the same occupation throughout working life, despite demanding working conditions and their physical capacity decreasing with age (Kilbom \& Torgén, 1996). The difference in health problems because of occupation was found in one study to remain stable at older ages (Gueorguieva et al., 2009). However, another study reported that the health of those with a poor work environment and multiple health complaints before retirement seems to improve after retirement (Westerlund et al., 2009).

Some occupations in the health care sector, e.g. nursing assistants, medical secretaries and physiotherapists, describe their work situation as too physically demanding for them to extend their working life (Bengtsson \& Nilsson, 2004; Johansson \& Olofsson, 1996; Johansson \& Östergaard, 1998; Nilsson, 2005b; 2006; Sundberg, 2002). Physically demanding occupational tasks among construction workers also increase the risk of early retirement (Stattin, 2005). In addition, agriculture, forestry and fishing, transport, warehousing and construction occupations have some of the most dangerous work environments with more occupational injuries and fatalities among workers 55 years and older (Jones et al., 2012; Swedish Board of Agriculture, 2008). The risk of accidents and injuries in agriculture and forestry is more than twice that in most other professions in Sweden (Swedish Board of Agriculture, 2008). Despite this, farmers and self-employed people are overrepresented in the old age work force and work more often than many other occupations until an old age (Hernandez-Peck, 2008; SCB, 2007; Reed et al., 1998; Swedish Board of Agriculture, 2006; Pinzke, 2003; Pinzke \& Lundqvist, 2007; Thelin \& Holmberg, 2010; Villosio et al., 2008). Farmers and rural inhabitants also tend to be healthier than urban dwellers and to have fewer mental disorders, cardiovascular diseases and cancer than senior citizens in other occupational groups (Blair et al., 2005; Holmberg et al., 2004; Reed et al., 2008; Stiernström et al., 2001; Thelin \& Höglund, 1994; Voaklander et al., 1999; van der Meer, 2008). 
Ageing workers seem to be at higher risk of injuries in demanding work environments than younger workers due to decreased hearing, longer reaction time, problems with new information and using older equipment (McLaughlin \& Sprufera, 2011). Furthermore, any injuries incurred by older workers appear to be much more severe due to the longer recovery time (Mitchell et al., 2002; Myers et al., 2009; Nilsson \& Pinzke, 2011). However, other studies report that even if older workers have more serious injuries, they have less frequent work place injuries and diseases than younger workers (Silverstein, 2008). Remaining in work in old age seems not to be problematic in itself, but improvements in working conditions are an important area in order to facilitate and prolong the working life (Stattin, 2005). Furthermore, a rehabilitation programme showed working to be associated with reduced chronic pain among older participants (Persson et al., 2012). A Canadian study established that information, education and changes in the work process may decrease fatal injuries among older workers (Blahey, 2002). Regular health checks have also been found to be a disease prevention tool for older workers in occupations with a high safety risk (Hallsten \& Solhem, 1996).

\subsubsection{Mental work environment}

How is my mental work environment? Is my health affected by mental demands in my work situation? Are effort and reward in balance in my work situation? Are my health and wellbeing improved by my mental work environment?

Unhappiness at work is often associated with stress, a perception of high demands and lack of control, reluctance to take responsibility and initiative fatigue, but also boring work (Bengtsson \& Nilsson, 2004; Gardell et al., 1979; Karasek \& Theorell, 1990; Nilsson, 2004; 2006; 2007d). Those in low autonomy work retire earlier than those with greater flexibility to decide how their work should be conducted (Blekesaune \& Solem, 2005). Those who are not successful in their social work situation seem also to have a greater tendency for 'self-crediting absence' from work and withdrawal from working life to avoid social isolation at work (Trist \& Bamforth, 1951). Stress and mental demands in the work situation could affect one's body and cause physical aches and pains (Melin \& Wigaeus Tornquist, 2004). Some cases of occupational problems and ill-health are caused by translation of dissatisfaction with work and tasks into disease (Höög, 1985). The justification hypothesis claims that health is used as an excuse to leave working life early (Dwyer \& Mitchell, 1999). In particular, individuals with poor education, poor physical 
and mental health or a poor relationship to the work place and daily encounters with work, work mates or the work situation may choose withdrawal as a way out of the stress and strain (Beehr, 1986; Forma et al., 2005; Höög, 1985; Höög \& Stattin, 1995; Nilsson, 2005a; 2006; Nordenmark \& Stattin, 2009; Park, 2010; Siegrist et al., 2007; Stattin, 1998; Taylor \& Shore, 1995; Trist \& Bamforth, 1951). Retirement seems therefore to be a possible socially acceptable way to withdraw from demanding mental working conditions (Beehr, 1986; Bengtsson \& Nilsson, 2004; Canivet et al., 2012; Forma et al., 2005; Hallsten, 1996; Harkonmäki et al., 2006; Ilmarinen \& Louhevaara, 1999; Munnell et al., 2004; Nilsson, 2003b; 2005a; 2005b; 2006; Park, 2010; Pohjonen, 2001; Seisamo \& Klockars, 1997; Siegrist et al., 2007; Taylor \& Shore, 1995; Volkoff, 1998; von Bonsdorff, 2009; Warr, 1994). On the other hand, high negative stress in working life seems also to affect mental health negatively after retirement (Wahrendorf et al., 2012).

Different occupations have different types of stress in their work situations. Social service occupations, e.g. medical and healthcare personnel, teachers, policemen and social insurance personnel often have specific mentally stressful work situations (Andersson-Felé, 2002; Dysting, 1996; Eklund \& Rahm Hallberg, 2000; Fochsen et al., 2005; Isberg, 2002; Jönsson, 2005; Jönsson et al., 2003; Lawoko et al., 2004; Lill, 2007; Lipsky, 1980; Michélsen et al., 1999; Nilsson, 2004; Johansson \& Olofsson, 1996; Salinsky \& Sackin, 2004; Sundgren Grinup et al., 1996; Thomsen et al., 1999). They are the link between the clients/patient and the regulations/organisation and need to deal with and take care of other people's personal problems and sorrow at the same time as they need to take care of their own reactions (Lipsky, 1980). Nearly one-third of healthcare professionals and nearly half of psychiatric nursing assistants described their work as too mentally demanding to go on working beyond retirement age (Nilsson, 2005c). Self-perceived health seems to improve after retirement among those with high demands, low satisfaction, poor mental work environment or low occupational grade (Johnston \& Wang-Sheng, 2009; Sjösten et al., 2010; Westerlund et al., 2009). However, one study reported that older participants in a good working life often display better mental and physical health than pensioners of similar age (Muto et al., 2003). Successful ageing at age 70 and beyond can also be predicted by e.g. life control and previous higher education (Vaillant \& Mukamal, 2001). Being happy with work and one's profession and being appreciated are very important to perceptions of good health and to actual long-term health (Aronsson \& Lind, 2004; Bengtsson \& Nilsson, 2004; Nilsson, 2003a; 2005a; 2007c; Siegrist et al., 2007). A sustainable working life is reported to be characterised by 
dialogue, communication, participation, coherence, clarity, confidence and individual control over work (Thelander, 2003).

\subsubsection{Work pace and working time}

How are my working time and working pace? Do my working time and working pace affect my possibilities to remain in working life? Do I have enough time to recover and rest between my work days? Is it possible in my work situation to take a break when I need to?

Many studies have shown that older workers seem to need more time to rest, and highlight moderate working pace and working time as being important for the older work force in maintaining good health and extending working life (Beehr, 1986; Beehr et al., 2000; Forma et al., 2005; Grahn, 2003; Hallsten, 1996; Ilmarinen, 2006; Nilsson, 2003a; 2003b; 2005a; 2005b; 2007a; 2007d; Saurama, 2004; Taylor \& Shore, 1995). Chronic health problems are not particularly highly associated with decreasing working hours among older farmers who can adjust their own work (Marcum et al., 2011). However, the work pace and working time of most people in the work force are adjusted by managers and the employment contracts. Nevertheless, there are some ageadjusted management programmes which reduce work pace and working time, e.g. the Vattenfall 80-90-100 scheduleF ${ }^{2} \mathrm{~F}$ for workers aged 58 years and older. Evaluation of that schedule found an increased average retirement age, good work environment experience, no increased sick leave for older workers, good productivty and good economic profits for the company (Mykletun \& Furunes, 2011).

It has been reported that sleep becomes more fragmented with age, and that shift work increases health problems and work-related accidents in old age (Gander \& Signal, 2008). Rest and sleep problems also affect memory and cognitive functions (Hornung et al., 2005). Work stress, worries and pain are also independently associated with general sleep problems (Kristiansen et al., 2011). Sleep deprivation and sleep disturbance can affect people's cognition and concentration and increase the risk of accidents, and many work-related

\footnotetext{
${ }^{2}$ The 80-90-100 schedule allows older employees to work $80 \%$ of full-time employment while receiving $90 \%$ of their full-time salary, but earning $100 \%$ of pension points towards the statutory retirement programme (Mykletun \& Furunes, 2011).
} 
accidents and traffic accidents are caused by fatigue and sleep disturbance (Carter et al., 2003; Howard et al., 2004; Leger, 1994; Ulfberg et al., 1996; Åkerstedt et al., 2007). Between 15 and 20 per cent of traffic accidents are caused by fatigue (Gurubhagavatula et al., 2004; Horne \& Reyner, 1995; Åkerstedt et al., 2007; Åkerstedt et al., 2008). Sweden is one of the countries in EU where most people suffer from sleep disturbance, with 11 per cent of women and 6 per cent of the men suffering from fatigue and sleep disturbance (Statens Folkhälsoinstitut, 2008a; 2008b). This is problematic due to findings that the risk of health problems is three-fold higher among women who experience lack of recovery, feel exhausted and seldom feel well-rested between work shifts (Thiele Schwarz, 2008). However, a study with 14714 participants provided strong evidence that retirement causes a substantial and sustained decrease in sleep disturbance and concluded that this positive outcome is the result of elimination of work-related stress (Vahtera et al., 2009). Other studies have also found that mental fatigue and insomnia decrease after retirement (Härmä, 2012; Laaksonen et al., 2012; Westerlund et al., 2010). On the other hand, one study found that retired reported more sleep disturbance than those in the work force among persons 65-74 years of age (Stockholms läns landsting, 2012).

Declining working hours with increased age and gradual retirement rather than an abrupt end to working life are described to be better for health because they allow time for people to gradually make changes to their lifestyle (De Vaus et al., 2007; Nylén \& Torgén, 2002; Torgén et al., 2001). Having control over the timing and manner of leaving work for retirement makes it easier to plan the life change, and provides a great positive impact on mental and social wellbeing which persists after retirement (Nordenmark \& Stattin, 2009; De Vaus et al., 2007).

\subsubsection{Attitude to older workers from managers and in the organisation}

What is the attitude to me as an older worker? How about age discrimination? Do managers and others in the organisation see older workers as an impediment in the working process and too slow? Should older workers leave to give the younger and visionary a chance? Is there an attitude that older workers are valuable and important in the organisation?

Attitude to older workers in the organisation and among managers and coworkers is important in determining whether older workers want to extend their 
working life (Bengtsson \& Nilsson, 2004; Höög, 1985; Höög \& Stattin, 1995; Nilsson, 2006; 2007a 2011a; 2011b; Stattin, 2005; Vercruyssen, 2003). Purposeful activities and engagement with life and society lead to a feeling of being valued and increase successful ageing (Doyle et al., 2012). If the attitude is positive and older workers are treated as wise and with much experience and knowledge, this seems to increase the attraction to remain in working life (Bengtsson \& Nilsson, 2004; Forma et al., 2005; Ilmarinen, 2006; 2012; Saurama, 2004). On the other hand, lack of interest from the organisation and managers increases bitterness with life and longing for early retirement (Mein et al., 1998). Older workers pushed into retirement by labour market factors experience lower wellbeing than those who retire for other reasons (Artazcoz et al., 2010; Nordenmark \& Stattin, 2009). A study has shown that low manager support is associated with both lower work ability and lower willingness to continue working until 65 years of age (Oude Hengel et al., 2011). Due to the professional status and occupational opportunities, different occupations seem to provide different grades of incentives to continue working life (Marmot, 2004; Nilsson, 2006). How older workers experience their occupational role, culture, hierarchical position and discrimination is determined both by those inside the occupation, e.g. managers and co-workers, and those who meet them in a specific occupational role, e.g. customers, clients and patients (Abrahamsson \& Aarum Andersen, 2000; Bruzelius \& Skärvad, 2000; Christensen et al., 2005; Gardell et al., 1979; Goffman, 1959; Pingel \& Robertsson, 1998; Thunborg, 1999).

In working life, age is often used as a guide to employees' salary level, career possibilities and professional development in the work place (Glover \& Branine, 2001). People seem to be sorted into different categories, with a specific type of attitude and culture identity, due to the hierarchical place of their particular occupation in the organisation and society (Lindgren, 1992). Categorisation and discussions of homogeneous groups, e.g. a certain age range, can also easily lead to generalisations and stereotyping (Bengtsson \& Nilsson, 2004; Glover \& Branine, 2001; Nilsson, 2003b; 2006; 2007a; 2007b; 2011a; RFV, 2001). Ageism is defined to be prejudicial and discrimination based on age (Glover \& Branine, 2001). Ageism and age discrimination was first described by the Grey Panthers in their battle for older people's rights in the 1960s in USA, but the word ageism was not common in Europe before the 1990s (Duncan, 2001). The EU introduced a directive against age discrimination in 2000 (Directive 2000/78/EC), and in Sweden age was included in the discrimination law in 2008 (Diskrimineringslag 2008:567). However, age discrimination could be additional to other discriminations, e.g. 
due to gender. An English study found that managers described their female employees as older workers when they were 48 years of age and their male employees as older workers when they were 51 years (McGoldrick \& Arrowsmith, 2001). However, age discrimination has strong significant associations especially with men's retirement planning (Thorsen et al., 2011). Negative attitude to older workers and a stereotypical picture, for instance of older workers as stagnant and as an encumbrance, pushes people out of working life early (Bengtsson \& Nilsson, 2004; Forma et al., 2005; Höög \& Stattin, 1995; Ilmarinen, 2006; Lindgren, 1999; Nilsson, 2005a; 2006; 2007a; 2007d; 2011a; OECD, 2006; Saurama, 2004). Age is also sometimes considered a legitimate reason to refuse to employ or to terminate employment (McGoldrick \& Arrowsmith, 2001). Support from the organisation, managers, friends and family is particularly important for older workers to achieve better adaptability and deal with age discrimination in a better way (Cheung $\& \mathrm{Wu}$, 2012).

Age management is described as a tool to increase the possibility to extend working life (Ilmarinen, 2003). Different methods to manage the older worker's situation include e.g. reducing working hours, reducing work load and demands, increasing economic incentives, increased esteem and possibilities for learning despite old age, re-deployment to less demanding parts of the organisation. A study about age management found that managers' own senior career plan also influenced their dealings with extending the career of their older workers (Mykletun et al., 2012). Older male managers and female managers more often believe in actions to extend the career of older workers, but managers who plan early retirement themselves or younger male managers put less trust in age management achievements (Mykletun et al., 2012). Another study stated that budgets and demands on efficiency give the strongest restrictions to age-adjusted leadership (Furunes \& Mykletun, 2011). However, even though employers and organisations find that an ageing population and decreased work force is an important challenge, the paradox is that not many of those make practical actions to increase their older workers' possibility to extend their working life (Jensen \& Juul Møberg, 2012). In a study of municipal managers, only 41 per cent stated that it was important to keep their employees until 65 years of age, and only 14 per cent to keep their employees after 66 years of age (Nilsson, 2011a). Another study found that small and medium-sized enterprises (SME) or employers with 100 or fewer employees were generally less fond of older workers (Munnell et al., 2006). Despite this, smaller firm size increases the probability of older workers themselves wishing to extend their working life (Dittrich et al., 2011). Large 
employers, those with 1000 or more employees, were not as negative to older blue-collar workers, but not especially attracted to older white-collar workers (Munnell et al., 2006). In the increased globalised market competition, many organisations have introduced organisation models, e.g. lean production, the main propose being to reduce costs and minimise the production flow time (Johansson \& Abrahamsson, 2007). The threat is that former working problems will return with static working tasks, decreased possibility for reflection and learning, and reduced interest in the workers' total competence (Johansson \& Abrahamsson, 2007). People with any type of disease are more likely to end up outside employment when times are bad (Trist \& Bamforth, 1951; Wikman \& Marklund, 2003). Those new organisation models seem therefore to may be especially problematic in an age management view.

\subsubsection{Competence and possibility for skills development}

Is it possible to learn in old age? Do I have enough competence and skills to continue my working life? Would my possibilities and willingness to extend my working life improve if I had the opportunity to develop my competence? Do I have the same possibilities to obtain new knowledge and participate in new projects despite my age?

Older workers' level of education, competence, possibility for skills development, but also the possibility to use the skills, is important in their retirement planning (Forma et al., 2005; Järnfelt, 2010; Kilbom \& Torgén, 1996; Nilsson, 2005a; 2005b; 2007c; 2007d; Nylén \& Torgén, 2002; Soidre, 2005; Solem et al., 2001; Tuomi et al., 2001). The more highly educated have better self-rated health and their health does not decline as fast with increased age as that of the less well educated (Mirowsky \& Ross, 2008). In addition, one study indicated that men who are highly educated more often go on and work part-time even after 70 years of age (Ozawa \& Lum, 2005). On the other hand, old and sick individuals with the "wrong" education, competence and skills seem to be "pushed" out of the labour market, due to technological development, increasing competition and organisational trends (Stattin, 2005). Those who experienced being "pushed" out into retirement show lower psychosocial wellbeing (Nordenmark \& Stattin, 2009). Furthermore, if the retirement is initiated because the skills are no longer required, this is also negative to health, especially among men (Nordenmark \& Stattin, 2009). 
Fear, stress and exhaustion about learning new things, e.g. computer techniques, are an acknowledged reason for leaving working life early (Abrahamsson et al., 2003; Grahn, 2003; Nilsson, 2005b; 2011b). Speed, reaction time, focusing on important information and ignoring irrelevant information and the cognitive procedure of information processing take a longer time with increased age due to biological ageing (Hallsten, 1996; Mather, 2010; Nilsson, 2007c; Salthouse, 2000; 1996). If information is presented in a new way, it takes a longer time for older individuals than for younger to cognitively structure and organise the information and therefore to learn and react (Hallsten, 1996; Mather, 2010; Nilsson, 2007c; 2007d; Salthouse, 2000; Warr, 1994). Age-related declines in cognitive abilities such as memory and reasoning seem to be predicted by cardiovascular disease and physical abilities such as walking and balance (Mather, 2010). However, old age in itself seems not to decrease individuals' possibility to learn new things and to perform working tasks (Hallsten \& Solhem, 1996; Mather, 2010). The possibility to learn new things in old age is mostly determined by the individual's belief in their own potential to learn new things (Hallsten, 1996; Warr, 1994). A study with judges found that older workers had better qualitative performance in their work even if it was not as quantitatively good as that of younger workers (Backes-Gellner et al., 2011). The natural decrease in cognitive and physical capacity with age is often compensated for by the increased experience, knowledge and wisdom of older workers (Salthouse, 1996; WHO, 2002). If older individuals receive new information connected to their former experience and knowledge, their capacity to use the new information is better than that of younger individuals (Hallsten, 1996; Salthouse, 2000; 1996; Warr, 1994). Furthermore, the ability to quickly detect emotional information, general knowledge and unconscious learning declines only a little or even improves with increasing age (Mather, 2010). To make new learning easier and stress-free for older individuals, it is important to develop learning methods appropriate to connect to their former life experience (Östlund, 2008). Obstacles to new learning could easily be solved with continuing education, learning by doing and breaks (Hallsten \& Solhem, 1996). 


\subsubsection{Motivation and work satisfaction}

How is my motivation to work? Am I satisfied within my work and life situation? Am I satisfied and motivated by my working tasks? Do I long for retirement? Does my leisure always give more motivation and satisfaction than my work?

Feeling satisfied with daily work and receiving attention in the work situation have been cited as important factors in the intention to extend working life (Bengtsson \& Nilsson, 2004; Cobb-Clark \& Stillman, 2009; Forman et al., 2005; Grahn, 2003; Nilsson, 2003a; 2005a; 2005b; 2006; Saurama, 2004 Schnalzenberger et al., 2008; Siegrist et al., 2007). People are reported to continue working because they are satisfied and attached to their career work and committed to their organisation, whereas financial incentives are not the primary force motivating people to work (Wang \& Shultz, 2010). However, it is much better if older workers at the end of their working life go on working because they want to, and not because they have no other economic alternative (Hult \& Stattin, 2009). Viewing work as an important part of life and the attitude of managers and organisations to older workers are factors influencing the willingness of people in their 60s to work beyond 65 years of age (Higgs et al., 2003; Nilsson, 2007a; 2007d; 2011a; 2011b; Solem et al., 2001). Furthermore, those who participate in working life at upper age often perceive themselves to have better mental and physical health than those without meaningful tasks (Doyle et al., 2012; Ilmarinen, 1997; Muto et al., 2003). Bridging employment, i.e. employment after retirement from a full-time position, has been related to both retirement satisfaction and overall life satisfaction (Kim \& Feldman, 2000). On the other hand, individuals who are tired of work, who feel no work motivation or ability to keep working, are more likely to retire early (Bidewell et al., 2006; Higgs et al., 2003; Molinié, 2005).

Individual personality has in one study been described as a better predictor of retirement-life satisfaction than stated reasons for retirement (Robinson et al., 2010). One study indicated that older employees with longer time horizons and expecting to live longer also have a preference for later retirement (van Solinge $\&$ Henkens, 2009). Early life dissatisfaction seems to increase the risk of early retirement (Harkonmäki et al., 2009). One study found that men who were part of a multi-problem family, had dropped out of school early or had poor mental health earlier in life, but given some positive resources, e.g. a good marriage and enjoyment of vacation and play, were more satisfied with early retirement (Vaillant et al., 2006). On the other hand, other studies found individuals, 
especially men, with high socio-economic status and high status at work who retired early showed decreased mental health after retirement (Jokela et al., 2010; Vaillant et al., 2006). Those authors concluded that retirement decreases such people's status and life satisfaction.

Classic work theory has some important points on retirement planning. Classic work research theory states that attention and acknowledgment of people affect their wellbeing and worker productivity. This is named the Hawthorne effect, after the place at which the experiment was conducted (Roethlisberger \& Dicksson, 1939). Individuals who find themselves in a work situation which is less motivating and satisfactory, who feel less loyalty to the organisation or cannot raise their voice to make a difference, choose to "exit" as soon as they get an opportunity (Hirschman, 1970). Other classic work research describes less motivating and satisfaction factors at work to be: powerlessness and lack of freedom to control the work; people just doing a small specialised part of a whole, making it difficult for them to see the big picture and the importance of their work for the end-result; social isolation and the task not being rooted in the context of the surrounding society and culture; people not having the opportunity to express their sovereignty, potential and personality; and reduced self-respect, status and longing to escape from the situation (Blauner, 1973). On the other hand, participation in a group in the work place, positive social interactions and sense of community are particularly important for those who feel isolated by work tasks and can increase some satisfaction in the work situation (Trist \& Bamforth, 1951). Herzberg (1966) and Herzberg et al. (1959) described a theoretical two-factor model of the association between work environmental factors, work content and productivity. External work environment factors, e.g. good salary, physical work environment, relation to managers and co-workers, organisation policy and administration, prevent unhappiness with work and illness but do not cure occured illness. However, external work environment factors do not motivate work itself or increased productivity. On the other hand, work content, e.g. factors associated with work tasks such as creativity, effort-reward balance and success in work, increase the motivation to work and the productivity (Herzberg, 1966; Herzberg et al., 1959). The greater influence an individual has over his or her work, the greater their level of commitment (Gardell et al., 1979; Karasek \& Theorell, 1990). 


\subsubsection{Family/leisure pursuits and attitude to pension in the surrounding society}

What is the attitude to extended working life in my immediate surroundings and in society? Do I live alone? Is my partner retired or does he/she plan to retire soon? Do I need to take care of relatives and feel hindered in doing so by my work? Are my leisure pursuits much more stimulating than my work? Is leisure more stimulating if I have work as well?

Retirement is a major event and turning point in life. Retirement therefore needs preparation in advance by the individual and also by their marital or civil partner (Kulik, 2001). The prevailing attitude of society, marital status, whether the life partner is working, or whether the older worker wants to spend more time with relatives and leisure pursuits may influence individuals to withdraw from working life (Bengtsson \& Nilsson, 2004; Cobb-Clark \& Stillman, 2009; Disney \& Tanner, 1999; Forma et al., 2005; Friis et al., 2007; Grahn, 2003; Hanson Frieze et al., 2011; Höög, 1985; Marmot, 2004; Nilsson, 2005a; 2006; 2007b; Nylén \& Torgén, 2002; Vercruyssen, 2003). One study indicated that men with a greater network were more likely to work after 70 years than men with a smaller network (Ozawa \& Lum, 2005). However, if work is interacting with leisure activities and family commitments, retirement may be brought forward, but also vice versa (Mein et al., 1998). Some people describe work as an antagonist to leisure activities and a reason for early retirement (Nilsson, 2011b). On the other hand, a study of 28780 people in 27 European countries showed that those aged 50 years and older in all 18 occupations surveyed found that it easier than younger workers to fit their working hours to family and social commitments (Vendramin \& Valenduc, 2012).

Retirement seems not to affect the interest in voluntary work, even if retirement among men, but not women, increases the time spent on voluntary work (Dosman et al., 2006). Factors such as health status, education and religious commitment influence participation in unpaid voluntary work (Dosman et al., 2006). Another study found that a combination of paid work and volunteering reduced the rate of mental health decline in later life (Hao, 2008). Voluntary work can be a substitute for previous paid employment in order to maintain feelings of meaningfulness, usefulness and productivity. It has also been found that those pushed into retirement are not as likely to pick up a new activity as those who retired voluntarily (Dosman et al., 2006).

Many couples plan their retirement together (Bengtsson \& Nilsson, 2004; Grahn, 2003; Keating \& Marshall, 1980; Nilsson, 2005a; 2005b). Marital satisfaction pulls expectations towards retirement and spending more time together (Kubicek et al., 2010). However, some studies have found that having dependents in the household, regardless of whether these are children, elderly 
parents or an ill partner, influences retirement among women (Nilsson, 2007b; Weaver, 1994). Furthermore, couples that are individually and jointly reported to be most satisfied with retirement are those in which the female partner is not influenced to retire by the male partner (Smith \& Moen, 2011). Nevertheless, older women and older men are less likely to continue working if their partner has retired (Nilsson, 2007b; Ozawa \& Lum, 2005; Weaver, 1994). Retired men who have an employed spouse spend more time on household work (Dosman et al., 2006), but time spent on household tasks increases after retirement for both men and women (Dosman et al., 2006). However, one study found that not having a partner could contribute to lower interest in economic incentives in an extended working life, especially among men (Doerpinghause \& Feldman, 2001). Other studies have found that not having a partner could contribute to an extended working life because the leisure time is otherwise too long and sometimes the possibility for social inclusion is better at work for those living alone (Bengtsson \& Nilsson, 2004; Nilsson, 2011b). 


\section{Materials and Methods}

\subsection{Design overview}

Three of the studies included in this thesis were quantitative and crosssectional, and one was a qualitative study using semi-structured interviews (Table 1). A description of the four studies, including details of data collection, sampling, data analyses and ethical considerations, is provided below.

Table 1. Design overview of Papers I-IV

\begin{tabular}{|c|c|c|c|c|}
\hline & Paper I & Paper II & Paper III & Paper IV \\
\hline Title & $\begin{array}{l}\text { Factors influencing } \\
\text { the decision to } \\
\text { extend working } \\
\text { life or retire. }\end{array}$ & $\begin{array}{l}\text { Self-rated health } \\
\text { and diagnostic } \\
\text { disease associated } \\
\text { with early or } \\
\text { deferred retirement }\end{array}$ & $\begin{array}{l}\text { Occupational } \\
\text { injuries to senior } \\
\text { farmers in Sweden }\end{array}$ & $\begin{array}{l}\text { Why work beyond } \\
65 \text { ? Discourse on } \\
\text { the decision to } \\
\text { continue working } \\
\text { or retire early }\end{array}$ \\
\hline Participants & $\begin{array}{l}1792 \text { health care } \\
\text { personnel 55-64 } \\
\text { years of age }\end{array}$ & $\begin{array}{l}1756 \text { health care } \\
\text { personnel } 55-64 \\
\text { years of age }\end{array}$ & $\begin{array}{l}5646 / 223 \text { farmers } \\
18 \text { years and older }\end{array}$ & $\begin{array}{l}22 \text { rural dwellers, } \\
63-71 \text { years of age }\end{array}$ \\
\hline Method model & $\begin{array}{l}\text { Quantitative: } \\
\text { Cross-sectional } \\
\text { study } \\
\text {-Mailed survey }\end{array}$ & $\begin{array}{l}\text { Quantitative: } \\
\text { Cross-sectional } \\
\text { study } \\
\text { - Mailed survey }\end{array}$ & $\begin{array}{l}\text { Quantitative: } \\
\text { Cross-sectional } \\
\text { study } \\
\text {-Mailed survey } \\
\text { and telephone } \\
\text { survey }\end{array}$ & $\begin{array}{l}\text { Qualitative: } \\
\text { Semi structured } \\
\text { individual } \\
\text { interviews }\end{array}$ \\
\hline Analysis method & Logistic regression & $\begin{array}{l}\text { Logistic regression } \\
\text { McNemars test } \\
\text { Discriminant } \\
\text { analysis }\end{array}$ & $\begin{array}{l}\text { Chi-square } \\
\text { analysis }\end{array}$ & Discourse analysis \\
\hline
\end{tabular}




\subsection{Data collection}

\subsubsection{Paper I}

The initial study population consisted of 2822 individuals born 1940-1949 and aged 55-64 years at the time of the survey in 2004. Subjects were identified by the personnel register as being employed in the health and medical care service in Scania, the most southern county in Sweden. Working in the public sector was associated with early withdrawal from working life in a previous study. The study population had the same employer, which minimised the risk of different employment conditions, rehabilitation policies and retirement policies. The individuals in this study were sent a questionnaire by post. After two reminders, 1815 individuals answered the questionnaire. However, 23 individuals did not state whether they believe they can or want to work. Those individuals were excluded from the study, resulting in a total of 1792 individuals in the final study population. This corresponded to a response rate of $63.5 \%$ from the initial study population.

Two questions formed the basis for the outcomes in this study. The first question was whether the respondent wanted to work until 55-59, 60-64, 65, or $\geq 66$ years of age and the second question was whether the participant believed they can work until 55-59, 60-64, 65, or $\geq 66$ years of age. The response options were dichotomised at 65 years of age (i.e. working until $<65$ versus $\geq 65$ years of age).

Originally the participants filled in a questionnaire that included 158 statements. For each statement, the participants had five response options, ranging from fully agree to fully disagree. The answers to each statement were then sorted into three categories; fully agree, neither fully agree nor fully disagree, and fully disagree. Based on previous knowledge within this research field, the statements were sorted into nine areas. The selection of the statements was based on previous studies performed by our research group (Bengtsson \& Nilsson, 2004; Nilsson, 2003a) a literature review (Nilsson, 2003b), and other surveys (Torgén et al., 2001; Jönsson et al., 2003). The questionnaire was tested in a group of 15 individuals employed within the healthcare sector. Evaluation of this pilot process resulted in reformulation of a few statements.

Paper I used 65 of the 158 original statements. They were sorted into nine areas: (i) health (9 statements), (ii) personal economic incentives (8 statements), (iii) physical work environment (3 statements), (iv) mental work 
environment (9 statements), (v) work pace and working time (8 statements), (vi) managerial and organisational attitude to older workers (6 statements), (vii) competence and possibility for skills development (10 statements), (viii) motivation and work satisfaction (7 statements), and (ix) family/leisure pursuits and attitude to pension in society (5 statements).

\subsubsection{Paper II}

This study used the same data set as Paper I (for more information about data collection see above and Papers I and II). However, 59 individuals did not answer the questions about their self-rated health and diagnosed disease, which were the critical variables in this study, and were excluded from the study, which gave 1756 individuals in the final study population.

The basis for the 'self-rated health' variable was the following statement in the questionnaire: "I am currently experiencing good health/well-being". The response options were "High agree" to "Low agree". Regarding the variable "diagnosed disease", it was based on the statement "I have a diagnosed disease" with the answering options "Yes" or "No".

\subsubsection{Paper III}

The study was based on data collected in a comprehensive survey of work accidents in agriculture and forestry in 2004 (Pinzke \& Lundqvist, 2007). The data were collected by mail survey and telephone interviews.

The sample included farm owners in 2004 with at least 2 ha of arable land, with large herds of livestock (at least 50 cows, 250 cattle, 50 sows, 250 pigs, 50 ewes, or 1000 poultry, regardless of the amount of arable land), and enterprises with horticultural production (outdoor cultures of at least 0.3 ha or enterprises with at least $200 \mathrm{~m}^{2}$ of greenhouse area). The sample frame was constituted from the 2003 Swedish Farm Register (LBR). The total number of registered farms was 67 061, and a stratified sample of 7000 individuals was drawn from this to reflect the average distribution of farms in Sweden. The selected group received a mail questionnaire with 14 questions, and 81\% (5062 farmers and 584 legal persons) responded to the questionnaire after two reminders. One of the questions was: "Did any accidents occur on the farm during 2004?" In the study, "accident" was defined as a sudden incident that resulted in bodily injury and hindered daily work. Those who responded in the 
affirmative to this question (a total of 393 farmers) were contacted for a telephone interview. Altogether, they reported 460 accidents involving the farmer, an employee, a family member, etc. The telephone interview consisted of 10 questions about the event, the injury, and health care contact for every reported accident on the farm. The final sample consisted of only injured farmers with agricultural, combined agricultural/forestry, horticultural, and other businesses related to agriculture, excluding legal persons. This gave 223 respondents, which constituted the sample in this study.

\subsubsection{Paper IV}

The data in this qualitative study were collected by semi-structured interviews (Kvale, 2001). The questions asked in these interviews were intended to provide a deeper understanding and knowledge about older people's own subjective experience and perspective of their situation and work environment. A person working beyond 65 years was defined as an "older worker" and a person who had left working life before 65 as an "early retiree". The investigation did not seek to provide a complete picture of the total complexity of retirement in Sweden's pension system, but to illustrate the process of retirement planning and people's self-perceived identity as early retiree or older worker.

The interviewees in the study were recruited in three steps from a register provided by an earlier work environment study (FAJ-Frisk av jobbet) of 1782 men living in rural areas in Sweden. In the first step, letters were sent to 229 people in the cohort living in two southern counties in Sweden. The covering letter stated that we were interested in interviewing people about working life and retirement. The letter was accompanied by a questionnaire asking whether the interviewees worked more than 10 hours a week or whether they had left working life and were retired. A total of 61 individuals responded to the questionnaire; 26 individuals who had either left working life before they were 65 years or were working beyond 65 were telephoned. In the last step, those were asked if they wanted to take part in the interview study. Of those, 22 persons agreed to participate in the study. They comprised five farmers and six individuals with other occupations who had left employment before 65 years of age, and six farmers and five individuals with other occupations who were working more than 20 hours per week and were over 65 years of age. After those interviews, the data were deemed to be satisfactory and no more individuals were included in the study. 
Each interview was conducted in the interviewee's home during 2010-2011 and took 1-4 hours. One interviewee declined to be recorded and that interview was documented in writing at the time of the interview, while the other 21 interviews were voice-recorded. Before the interviews began, informed written consent to participate was obtained from the interviewees. On completion of the interviewing work all audiotapes were transcribed, but the identity of interviewees was concealed. The interviews were semi-structured using an interview guide which included questions about the interviewees: growing up; relatives; normal day; leisure; health now and earlier in life; age; working life; working environment; motivation in work and life; work and life satisfaction; working tasks and ageing; important things and others in life; retirement decision; why they were working or retired; why they think people in general leave work before 65 years of age; and why they think people in general work after 65 years of age.

\subsection{Sample}

\subsubsection{Paper I and II}

The median age among the participants was 59 years and the majority of the participants were women (84\%). In addition, women had a higher response rate (68\%) compared with men (59\%). The distribution of occupations among the participants was: $21 \%$ nurses, $20 \%$ medical secretaries, $17 \%$ physicians, $15 \%$ nursing assistants, $7 \%$ physiotherapists, $7 \%$ welfare officers, $5 \%$ psychologists, $5 \%$ psychiatric nursing assistants, and 3\% occupational therapists. In all, 13\% of the respondents were on part- or full-time sick leave and $16 \%$ had a part- or full-time disability pension. Of the participants, $91 \%$ were born in Sweden, $4 \%$ in another Nordic country, 4\% in non-Nordic European country and 1\% outside Europe. As regards civil status, $75 \%$ of the participants were married/co-habiting, $4 \%$ were partly co-habiting and $21 \%$ were single. Among the participants with a partner, $61 \%$ had a partner who worked full-time, $13 \%$ had a partner who worked part-time, and $26 \%$ had a partner who did not work at all.

The proportion of the total non-participants was about $37 \%$ and the median age was 58 years. The highest non-participants proportion was among physicians (25\%) and the lowest among physiotherapists, occupational therapists, psychologists and welfare officers (14\%). 


\subsubsection{Paper III}

The age distribution in this study was comparable to that in the total population of farmers in Sweden in 2005. This number amounted to $61 \%$ of the respondents and $62 \%$ of all farmers in Sweden who were older than 50 years. Among the respondents in the mail survey, 32\% were 50-59 years old, and the percentage of this age group among all farmers in Sweden was 28\%. Taken together, 34\% of farmers in Sweden were 60 years old or older in the year of the study, and this age group was represented by $29 \%$ of respondents in the mail survey. Of the injured farmers who answered the telephone interview, $38 \%$ were 49 years old or younger, $38 \%$ were $50-59$ years old, and $24 \%$ were 60 years or older. This created a data set in which the proportion below and above 50 years was approximately the same as in the total group of farmers in Sweden.

The proportion of non-participants was 19\%. A non-participant analysis performed with telephone interviews by Statistics Sweden found that the nonparticipants were not significantly different from the participants in the study.

\subsubsection{Paper IV}

The interviewees were men 63-71 years of age, with a median age of 68 years. Those who were still working beyond 65 years had a median age of 71 years, while those who had left working life before 65 years had a median age of 66 years when they were interviewed. Nine of the interviewees in each group were married or cohabiting, and seven in each group had children. Nineteen of the 22 interviewees had grown up on farms. However, all participants lived or had lived in the countryside, e.g. in a cottage, farmhouse, smallholding or forestry property. Five of those in the group that had left working life early and four in the group that continued working after 65 years had been diagnosed with a chronic disease that affected their general health negatively. Six of those who continued to work after 65 years of age were self-employed and five had other occupations. Two of the farmers had also had, or continued to have, another job outside the farm. Five of those who had stopped working before 65 years of age had been self-employed farmers, four of whom had had another job outside the farm, and six had had other occupations.

Three of the persons who declined to be included in the study stated that they did not have time or were not interested when they were telephoned and asked 
to participate. An interview time was decided with one person, but he called on the very same morning and declined the interview because of lack of time.

\subsection{Data analysis}

\subsubsection{Paper I}

Logistic regression models generating odds ratios (OR), 95\% confidence intervals $(95 \% \mathrm{CI}$ ) and $\mathrm{P}$-values were used to investigate the statements associated with the outcomes "want to work until age 65 years or beyond" and "can work until age 65 years or beyond". For each of the two outcomes, we used the following analytical strategy.

Analyses within each of the nine areas (see description of the nine areas above): We started with univariate analyses (i.e. we evaluated the associations for one statement at a time). In a second step, we kept the statement with the lowest $\mathrm{P}$-value (if $\mathrm{P}<0.05$ ) and tentatively included all other statements, one at a time. In a third step, we kept the two statements with the lowest P-values (if both $\mathrm{P}<0.05)$ and tentatively included the remaining statements one at a time. This procedure continued for as long as the P-values for all included statements was $\mathrm{P}<0.05$.

Analyses including all nine areas: We started by including the selected statements from areas (i) and (ii) in a multivariate model (i.e. the areas "physical and mental health" and "personal economic incentives"). The statements with P-values $<0.05$ were kept in the model to the next step, in which we also included the selected statements from area (iii). This procedure continued until all nine areas were included in a final model. After that, the statements removed from the nine areas were tested, one at a time, in the final model, to check once more whether the model was robust.

Background variables: In the final multivariate model, we also evaluated the importance of background variables (age, gender, and marital status) by including them in the model. 


\subsubsection{Paper II}

Association between the health measures: The association between the two health measures (self-rated health and diagnosed disease) was tested with McNemars test. In addition, separate analyses were performed for subgroups based on gender, age and retirement planning, respectively. $\mathrm{P}<0.05$ was defined as statistically significant.

Association between the nine statement areas and the health measures: Logistic regression models (generating OR, 95\% CI and P-values) were used to investigate which statements within the nine areas were associated with the health outcomes (i.e. diagnosed and self-rated health) (see description of the nine areas in Paper I). For each of the two outcome variables, we used the following analytical strategy:

a) Analyses within each of the nine areas: First univariate analyses were made, i.e. the association for one variable at a time was evaluated and the variable with $\mathrm{P} \leq 0.05$ was kept. In the second step, we kept the statement with the lowest $\mathrm{P}$-value (if $\mathrm{P}<0.05$ ) and tentatively included all other statements, one at a time. In a third step, we kept the two statements with lowest P-values (if both $\mathrm{P}<0.05)$ and tentatively included the remaining one at a time. This procedure continued as long as the P-values for all included variables were $\leq 0.05$.

b) Analyses including all nine areas: The analysis started by including the selected variables from area i) and area ii) in a multivariate model (i.e. the themes "Physical and mental health" and "Personal economy incitements"). The variables with $\mathrm{P} \leq 0.05$ were kept in the model to the next step, which also included the selected variables from area iii). This procedure continued until all nine areas were included in a final model. After that, the variables removed from the nine areas were tested one at a time to the final model to check once more whether the model was robust.

Association between the health measures and retirement planning: Logistic regression models were used for evaluating the associations between the health measures (self-rated health and diagnosed disease, respectively) and if they think they can work work until $<65$ or $\geq 65$. Univariate (i.e. one health measure at a time) and multivariate analyses were performed. In the multivariate models, potential confounders were taken into consideration. The selection of confounders was based on the above-described associations between the nine statement themes and the health measures and on previous 
analyses within the same cohort regarding the associations between the nine statement areas and the "can work until" perspective.

Association between the combination of health measures and retirement planning: In the last step the two health measures were combined into three new groups developed from the outcome variables "self-rated health" and "diagnosed disease". Discriminant analysis was used and included all the original statements from the nine areas to test the robustness of the health measure models and to distinguish the three combinations of groups. Classifying the proportion of persons into the correct group gives a good probability of allocating (diagnosing) new persons correctly as believing they can extend their working life or must retire, based on their health measures. The discriminant analysis was performed with Wilks' Lambda and the variable in the analysis was statistically significant at $\mathrm{P} \leq 0.05$.

\subsubsection{Paper III}

The data were descriptively presented as percentage by age group and analysed by cross tables and chi-squared test.

\subsubsection{Paper IV}

The interviewees' descriptions were analysed in order to get a better understanding of the process of retirement planning and pension decision making. People use language to describe contrasts between different poles in the topic under discussion and to justify their actions as normal and moral (Winter Jørgensen \& Phillips, 2006; Widerberg, 2002; Wetherell et al., 2001; Burr, 1995). Words are given their importance through distinction from other words within a special situation and can have different meanings in different contexts (Winter Jørgensen \& Phillips, 2006). An individual's identity is a social construct and involves common sense knowledge of oneself and the surrounding world (Burr, 1995). In this study "work" refers to occupational work, while "retirement" refers to final cessation of occupational work. The discourse of work relating to retirement constitutes people's social identity as older worker or early retiree. Discourse analysis was used to evaluate the interviewees' use of different types of discursive practice in their descriptions, e.g. as a resource to reinforce their storyline to support their social arrangements relating to their social identity as older worker or early retiree 
(Fairclough, 1992; Hall, 2001). The analysis also sought to understand how the interviewees ranked their different statements. Their descriptions were sorted into themes and ranked in order of their reported importance to the interviewees' retirement decisions. The results of this analysis were used to construct a model of the interviewees' retirement decisions.

\subsection{Ethical considerations}

\subsubsection{Papers I - II}

Subjects were identified by the personnel register in the health and medical care service in Scania, the most southern county in Sweden. The initial study population consisted of 2822 individuals born 1940-1949. Those employees received the mail questionnaire distributed by TEMO (Testhuset Marknad Opinion $\mathrm{AB}$ ). The questionnaire was followed by a letter with information about the study and asking for written informed commitment to be included in the study population. After two reminders, 1878 individuals answered the questionnaire. However, 43 of those had not returned their signed informed commitment document and were excluded from the study.

\subsubsection{Paper III}

Statistic Sweden (SCB) sent a mail questionnaire to 7000 farmers included in the Swedish Farm Register (LRF) and 5646 farmers or legal representatives responded. SCB contacted the 393 injured farmers by telephone asking for the possibility to make a telephone interview. The farmer's identity was removed and recoded with a list number in the data file by SCB.

\subsubsection{Paper IV}

The study received approval to be implemented from the Central Ethical Review board in Lund (protocol 2010/02). Before the interviews began, informed written consent to participate was obtained from all interviewees. The identity of the interviewees was concealed and anonymous before the audiotapes were transcribed. 


\section{Results}

The results presented in detail in Papers I-IV are summarised below.

\subsection{Paper I: Factors influencing whether older workers believe they "can" and "want to" extend their working life.}

Of the 1792 respondents, $54 \%$ stated that they "can work until 65 years or beyond". The proportion of individuals who stated that they "want to work until 65 years or beyond" was 38\%. The nine defined areas made up by 65 statements were analysed with respective outcome measures "can" and "want to".

In the final multivariate model with "can work until 65 years or beyond", 11 statements were statistically significantly associated (Table 2). Three statements were from the area "Personal economic incentives" and two from the area "Health". Those areas that were not represented in the final model were "Motivation and work satisfaction" and "Attitude to older workers from managers and in the organisation". The strongest observed association, defined as the highest OR, was for the statement "I hope for an offer from my employer to stop working before age 65" (OR 4.3, 95\% CI 3.2-5.9). The second strongest association was observed within the statement "My work is too mentally demanding for working until age 65 or beyond" (OR 4.0, 95\% CI 2.8-5.7). When the background variables age, gender and marital status were included in the final model, the ORs changed only marginally.

In the final multivariate model with "I want to work until 65 years of age or beyond five statements from the area "Personal economic incentives", three from the area "Family/leisure pursuits and attitude to pension in society", and two from the area "Attitude to older workers from managers and in the 
organisation" qualified for the final model. The strongest association was observed for the statement "I will probably stop working before age 65 through an early age pension" (OR 8.6, 95\% CI 4.8-15). A strong association was also observed for the statement "I hope for an offer from my employer to stop working before age 65" (OR 7.9, 95\% CI 5.4-11). When we included the background variables age, gender and marital status in the final model, the ORs changed only marginally. 
Table 2. Distribution of "can" and "want to" outcomes for statements included in the final multivariate model. Increased odds ratio $(O R)$ indicates individuals believed they have increased possibility to work $\geq 65$ years of age $(95 \% C I=95 \%$ confidence interval; $R$ ef $=$ reference $)$.

(Source: Paper I)

"I can work until ...."

\begin{tabular}{|c|c|c|c|c|}
\hline \multirow[t]{2}{*}{$\begin{array}{l}\text { Agree or disagree with } \\
\text { the statement in each area }\end{array}$} & \multicolumn{2}{|c|}{$\begin{array}{l}\text { Univariate } \\
\text { estimates }\end{array}$} & \multicolumn{2}{|c|}{$\begin{array}{c}\text { Multivariate } \\
\text { model }\end{array}$} \\
\hline & OR & $95 \% \mathrm{Cl}$ & $\overline{\mathrm{OR}}$ & $95 \% \mathrm{Cl}$ \\
\hline \multicolumn{5}{|l|}{ Physical and mental health } \\
\hline \multicolumn{5}{|l|}{ I feel mentally worn out } \\
\hline Partly agree & 2.1 & $1.6-2.7$ & 0.9 & $0.6-1.4$ \\
\hline Disagree & 4.1 & $3.2-5.4$ & 1.7 & $1.1-2.5$ \\
\hline \multicolumn{5}{|c|}{$\begin{array}{l}\text { I have bad health and have/am probably } \\
\text { going to get disability pension before age } 65\end{array}$} \\
\hline Agree & Ref & & Ref & \\
\hline Partly agree & 5.0 & $3.5-7.2$ & 1.6 & $1.7-4.3$ \\
\hline Disagree & 3.3 & $3.3-6.2$ & 2.6 & $1.4-3.4$ \\
\hline \multicolumn{5}{|c|}{ Personal economic incentives } \\
\hline \multicolumn{5}{|c|}{$\begin{array}{l}\text { I am saving in different ways to make it } \\
\text { possible to stop working before age } 65 \text {. }\end{array}$} \\
\hline Agree & Ref & & Ref & \\
\hline Partly agree & 2.9 & $2.2-3.8$ & 1.6 & $1.1-23$ \\
\hline Disagree & 6.9 & $5.5-8.8$ & 2.6 & $1.9-3.6$ \\
\hline \multicolumn{5}{|c|}{$\begin{array}{l}\text { My intention is to work beyond age } 65 \text { to } \\
\text { get a better pension }\end{array}$} \\
\hline Disagree & Ref & & Ref & \\
\hline Partly agree & 3.0 & $2.1-4.1$ & 1.8 & $1.1-2.8$ \\
\hline Agree & 5.4 & $3.9-7.6$ & 1.9 & $1.2-3.0$ \\
\hline \multicolumn{5}{|c|}{$\begin{array}{l}\text { I hope for an offer from my employer to } \\
\text { stop working before age } 65\end{array}$} \\
\hline Agree & Ref & & Ref & \\
\hline Partly agree & 3.7 & $2.7-5.0$ & 2.1 & $1.4-3.1$ \\
\hline Disagree & 13 & $10-17$ & 4.3 & $3.2-5.9$ \\
\hline \multirow{2}{*}{\multicolumn{5}{|c|}{$\begin{array}{l}\text { Physical work environment } \\
\text { My work is too physically demanding for } \\
\text { working age } \geq 65 \text { years }\end{array}$}} \\
\hline & & & & \\
\hline Agree & Ref & & Ref & \\
\hline Partly agree & 2.4 & $1.7-3.3$ & 1.4 & $0.9-2.1$ \\
\hline Disagree & 6.3 & $4.6-8.6$ & 2.2 & $1.5-3.4$ \\
\hline \multicolumn{5}{|c|}{ Mental work environment } \\
\hline \multicolumn{5}{|c|}{$\begin{array}{l}\text { My work is too mentally demanding for } \\
\text { working age } \geq 65 \text { years }\end{array}$} \\
\hline Agree & Ref & & Ref & \\
\hline Partly agree & 3.5 & $2.7-4.6$ & 2.1 & $1.4-3.0$ \\
\hline Disagree & 12 & $9.2-15$ & 4.0 & $2.8-5.7$ \\
\hline \multicolumn{5}{|c|}{ Working pace and working time } \\
\hline \multicolumn{5}{|c|}{ The working pace in my daily work is rapid } \\
\hline Agree & Ref & & Ref & \\
\hline Partly agree & 1.4 & $1.1-1.8$ & 1.0 & $0.7-1.5$ \\
\hline Disagree & 2.5 & $1.9-3.1$ & 1.5 & $1.0-21$ \\
\hline \multicolumn{5}{|c|}{$\begin{array}{l}\text { Competence and possibility for skills } \\
\text { development }\end{array}$} \\
\hline \multicolumn{5}{|c|}{$\begin{array}{l}\text { I feel that my competence is used in a } \\
\text { satisfactory way within the organisation }\end{array}$} \\
\hline Disagree & Ref & & Ref & \\
\hline Partly agree & 1.0 & $0.7-1.4$ & 1.8 & $1.2-2.9$ \\
\hline Agree & 1.6 & $1.2-2.1$ & 1.6 & $1.1-2.5$ \\
\hline \multicolumn{5}{|c|}{$\begin{array}{l}\text { Due to my age I get fewer possibilities to } \\
\text { be supervised }\end{array}$} \\
\hline Agree & Ref & & Ref & \\
\hline Partly agree & 1.5 & $1.1-1.9$ & 1.1 & $0.7-1.5$ \\
\hline Disagree & 1.1 & $0.8-1.5$ & 0.6 & $0.4-0.9$ \\
\hline \multirow{2}{*}{\multicolumn{5}{|c|}{$\begin{array}{l}\text { Family/leisure pursuits and attitude to } \\
\text { pension in society } \\
\text { I will stop working before age } 65 \text { when }\end{array}$}} \\
\hline & & & & \\
\hline Agree & Ref & & Ref & \\
\hline Partly agree & 3.6 & $2.7-4.9$ & 2.2 & $1.5-3.3$ \\
\hline Disagree & 8.5 & $6.4-11$ & 3.8 & $2.6-5.4$ \\
\hline
\end{tabular}

"I want to work until...."

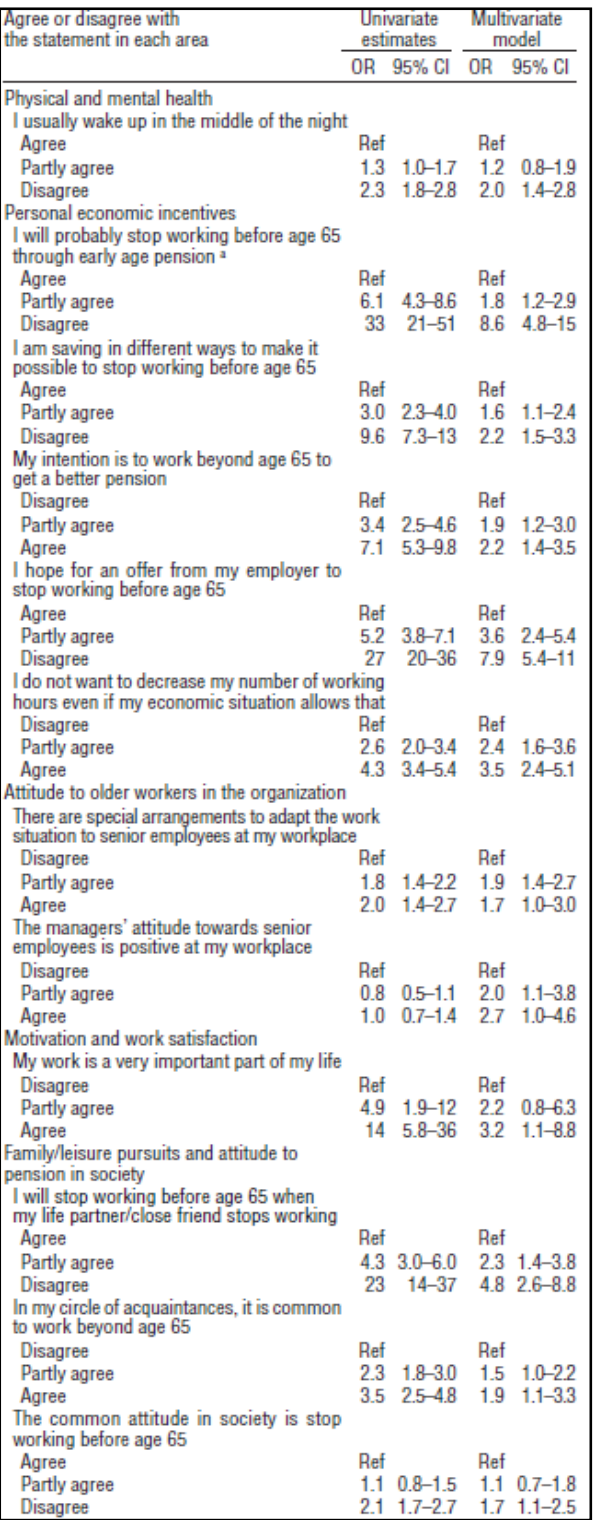




\subsection{Paper II: Influence of factors associated with older workers diagnosed disease and self-rated health on retirement planning.}

Most of the participants in this study had high self-rated health (67\%) and no diagnosed disease $(56 \%)$. In the study population $53 \%$ believed they could work until 55-64 years of age, and 47\% believed they could work until 65 years of age or beyond. Among those with high self-rated health, $62 \%$ believed they could work until 65 years of age. Of those who had a diagnosed disease, $46 \%$ believed they could work until 65 years of age or beyond. Furthermore, $54 \%$ stated that their diagnosed disease was caused by their work and $62 \%$ stated that their diagnosed disease was an obstacle in their daily work.

The nine defined areas including 65 statements were analysed with respective outcome measures "diagnosed disease" and "self-rated health". In the final multivariate model, diagnosed disease was most highly associated with "I mostly manage physical working demands in my daily work" (OR 2.4, 95\% CI 1.7-3.5) and "I feel physically worn out" (OR 2.3, 95\% CI 1.7-3.2). The association changed only marginally when the background variables age, gender, marital status and occupation were included in the final model (Table 3).

Table 3. Distribution regarding "diagnosed disease" outcomes for statements in the final multivariate model. Increased odds ratio (OR) indicates an individual with a diagnosed disease. (95\% confidence interval (CI); Ref=reference). (Source: Paper II)

\begin{tabular}{|c|c|c|c|c|c|c|}
\hline \multirow[t]{2}{*}{ Area } & \multirow[t]{2}{*}{ Statement } & \multirow{2}{*}{$\begin{array}{l}\text { Agree/ } \\
\text { disagree } \\
\text { with the } \\
\text { statement }\end{array}$} & \multicolumn{2}{|c|}{$\begin{array}{l}\text { Univariate } \\
\text { estimate }\end{array}$} & \multicolumn{2}{|c|}{$\begin{array}{l}\text { Multivariate } \\
\text { model }\end{array}$} \\
\hline & & & OR & $95 \% \mathrm{Cl}$ & OR & $95 \% \mathrm{Cl}$ \\
\hline \multirow[t]{3}{*}{ Health } & \multirow[t]{3}{*}{ I feel physically worn out } & Disagree & Ref. & & Ref. & \\
\hline & & Partly agree & 2.3 & $1.7-2.9$ & 1.7 & $1.3-2.3$ \\
\hline & & Agree & 3.6 & $2.7-4.7$ & 2.3 & $1.7-3.2$ \\
\hline \multirow{3}{*}{$\begin{array}{l}\text { Physical work } \\
\text { environment }\end{array}$} & \multirow{3}{*}{$\begin{array}{l}\text { I mostly manage physical } \\
\text { working demands in my daily } \\
\text { work }\end{array}$} & Agree & Ref. & & Ref. & \\
\hline & & Partly agree & 2.1 & $1.9-4.6$ & 2.3 & $1.5-3.7$ \\
\hline & & Disagree & 3.1 & $2.2-4.4$ & 2.4 & $1.7-3.5$ \\
\hline \multirow{6}{*}{$\begin{array}{l}\text { Working pace and } \\
\text { working time }\end{array}$} & \multirow{3}{*}{$\begin{array}{l}\text { The working pace in my daily } \\
\text { work is too rapid }\end{array}$} & Disagree & Ref. & & Ref. & \\
\hline & & Partly agree & 0.8 & $0.7-1.1$ & 0.6 & $0.5-0.8$ \\
\hline & & Agree & 1.3 & $1.0-1.6$ & 0.8 & $0.7-1.1$ \\
\hline & \multirow{3}{*}{$\begin{array}{l}\text { I feel that I get enough } \\
\text { rest/relaxation between my } \\
\text { working days }\end{array}$} & Agree & Ref. & & Ref. & \\
\hline & & Partly agree & 2.4 & $1.9-3.0$ & 1.7 & $1.3-2.2$ \\
\hline & & Disagree & 2.1 & $1.7-2.7$ & 1.8 & $1.4-2.4$ \\
\hline
\end{tabular}


In the final multivariate model associated with the outcome variable "self-rated health", the highest association was observed for the statements: "I feel physically worn out" (OR 4.1, 95\% CI 2.8-6.1) and "I am satisfied with my present work situation" (OR 2.9, 95\% CI 1.8-4.4) (Table 4). The association changed only marginally when the background variables age, gender, marital status and occupation were included in the final models.

Table 4. Distribution regarding "self-rated health" outcomes for statements in the final multivariate model. Increased odds ratio (OR) indicates that the individual experienced low selfrated health. (95\% confidence intervals $(\mathrm{CI})$; Ref=reference). (Source: Paper II)

\begin{tabular}{|c|c|c|c|c|c|c|}
\hline \multirow[t]{2}{*}{ Area } & \multirow[t]{2}{*}{ Statement } & \multirow{2}{*}{$\begin{array}{l}\text { Agree/ } \\
\text { disagree } \\
\text { with the } \\
\text { statement }\end{array}$} & \multicolumn{2}{|c|}{$\begin{array}{l}\text { Univariate } \\
\text { estimate }\end{array}$} & \multicolumn{2}{|c|}{$\begin{array}{l}\text { Multivariate } \\
\text { model }\end{array}$} \\
\hline & & & OR & $95 \% \mathrm{Cl}$ & OR & $95 \% \mathrm{Cl}$ \\
\hline \multirow[t]{9}{*}{ Health } & \multirow[t]{3}{*}{ I feel mentally worn out } & Disagree & Ref. & & Ref. & \\
\hline & & Partly agree & 5.0 & $3.8-6.6$ & 1.6 & $1.1-2.3$ \\
\hline & & \begin{tabular}{|l|} 
Agree \\
\end{tabular} & 9.0 & $6.9-12$ & 1.8 & $1.3-2.6$ \\
\hline & \multirow[t]{3}{*}{ I feel physically worn out } & Disagree & Ref. & & Ref. & \\
\hline & & Partly agree & 5.8 & $4.4-7.6$ & 2.5 & $1.8-3.6$ \\
\hline & & \begin{tabular}{|l|} 
Agree \\
\end{tabular} & 13 & $9.2-17$ & 4.1 & $2.8-6.1$ \\
\hline & \multirow[t]{3}{*}{ I seldom feel rested } & Disagree & Ref. & & Ref. & \\
\hline & & Partly agree & 3.6 & $2.7-4.9$ & 1.6 & $1.1-2.2$ \\
\hline & & \begin{tabular}{|l|} 
Agree \\
\end{tabular} & 7.9 & $6.2-10$ & 1.9 & $1.3-2.7$ \\
\hline \multirow{3}{*}{$\begin{array}{l}\text { Physical work } \\
\text { environment }\end{array}$} & \multirow{3}{*}{$\begin{array}{l}\text { I mostly manage physical working } \\
\text { demands in my daily work }\end{array}$} & Agree & Ref. & & Ref. & \\
\hline & & Partly agree & 3.2 & $2.1-4.9$ & 1.9 & $1.1-3.2$ \\
\hline & & Disagree & 3.1 & $2.2-4.4$ & 1.7 & $1.1-2.7$ \\
\hline \multirow{3}{*}{$\begin{array}{l}\text { Working pace and } \\
\text { working time }\end{array}$} & \multirow{3}{*}{$\begin{array}{l}\text { I feel that I get enough } \\
\text { rest/relaxation between my } \\
\text { working days }\end{array}$} & Agree & Ref. & & Ref. & \\
\hline & & Partly agree & 9.5 & $7.3-12$ & 2.3 & $1.6-3.3$ \\
\hline & & Disagree & 4.8 & $3.6-6.4$ & 2.1 & $1.5-3.0$ \\
\hline \multirow{6}{*}{$\begin{array}{l}\text { Attitude to seniors in } \\
\text { the organisation }\end{array}$} & \multirow{3}{*}{$\begin{array}{l}\text { The manager's attitude towards } \\
\text { senior employees is positive at my } \\
\text { work place }\end{array}$} & Agree & Ref. & & Ref. & \\
\hline & & Partly agree & 2.5 & $1.8-3.5$ & 0.7 & $0.4-1.0$ \\
\hline & & Disagree & 2.5 & $1.9-3.3$ & 1.4 & $1.0-2.0$ \\
\hline & \multirow{3}{*}{$\begin{array}{l}\text { I feel discriminated against in my } \\
\text { work place because of my age }\end{array}$} & Disagree & Ref. & & Ref. & \\
\hline & & Partly agree & 3.8 & $2.5-5.6$ & 2.3 & $1.4-3.9$ \\
\hline & & \begin{tabular}{|l|} 
Agree \\
\end{tabular} & 2.8 & $1.9-4.1$ & 1.6 & $1.0-2.6$ \\
\hline \multirow{3}{*}{$\begin{array}{l}\text { Motivation and work } \\
\text { satisfaction }\end{array}$} & \multirow{3}{*}{$\begin{array}{l}\text { I am satisfied with my present work } \\
\text { situation }\end{array}$} & Agree & Ref. & & Ref. & \\
\hline & & Partly agree & 7.8 & $5.6-11$ & 2.9 & $1.8-4.4$ \\
\hline & & Disagree & 4.6 & $3.6-5.9$ & 2.1 & $1.6-2.9$ \\
\hline
\end{tabular}

In univariate models, self-rated health (high vs. low: OR 3.3, 95\% CI 2.7-4.1) and diagnosed disease (yes vs. no: OR 1.7, 95\% CI 1.4-2.1) were associated with the "can work until" outcome. When the health ratings were investigated simultaneously, self-rated health (high vs. low; OR 3.2, 95\% CI 2.5-4.0) but not diagnosed disease (no vs. yes; OR 1.1, 95\% CI 0.9-1.3) was significantly associated with the "can work until" outcome. Furthermore, diagnosed disease and self-rated health were examined separately in the logistic regression analysis, but in reality people have different combinations of diagnosed 
disease/no diagnosed disease and low/high self-rated health. To analyse older workers' health rating combination in more depth, three new groups were constructed from the variables on self-rated health and diagnosed disease:

- Group 1 included $25 \%$ of the respondents and represented those who reported both low self-rated health and diagnosed disease. In group 1 the most common occupations were physician, welfare officer and psychiatric nursing assistant. The median age in this group was 59 years, and included more women than expected, and 68\% believed they could work until 55-64 years and $32 \%$ until 65 years or beyond.

- Group 2 included $28 \%$ of the respondents and was a combination of the two smallest and similar group combinations: those who reported low self-rated health and no diagnosed disease, and those who reported high self-rated health and a diagnosed disease. The most common occupations in group 2 were medical secretary and physiotherapist. The median age in group 2 was 59 years, and included more women than expected, and $45 \%$ believed they could work until 55-64 years of age and 55\% until 65 years or beyond.

- Group 3 included $47 \%$ of the study population and represented those who reported both high self-rated health and no diagnosed disease. The most common occupations in this group were nurse, occupational therapist, psychologist and nursing assistant. The median age was 58 years, and included more men than expected, and $38 \%$ believed they could work until $55-64$ years and $62 \%$ until 65 years or beyond.

The combination of variables that maximised the separation between the groups was analysed with discriminant analysis. The two functions determined in the analysis were: Function 1: "Physical and mentally worn out in relation to work satisfaction" including two variables from the area "health" ("I feel physically worn out"; "I feel mentally worn out") and one variable from the area "Motivation and work satisfaction" ("I am satisfied with my present work situation") ( $\mathrm{P}<0.001)$; Function 2: "Opportunities for recovery" included two variables from the area "Health" ("I often wake up in the middle of the night"; "I seldom feel rested"), and one variables from the area "Working pace and working time" ("I feel that I get enough rest/relaxation between my working days") $(\mathrm{P}<0.001)$. The centroid value of the three groups placed them in a negative or a positive dimension in relation to the two functions "physically and mentally worn out in relation to work satisfaction" and "opportunity for 
recovery" and to each other, but also to the direction to extend working life (Figure 3).

After splitting the file into those who believed they "can work until 65 years of age or beyond" and those who believed they "can work until 55-64 years of age", two new discriminant analyses were performed. Despite this, the centroid value only changed marginally and the variables included in the functions associating with the health rating groups did not change.

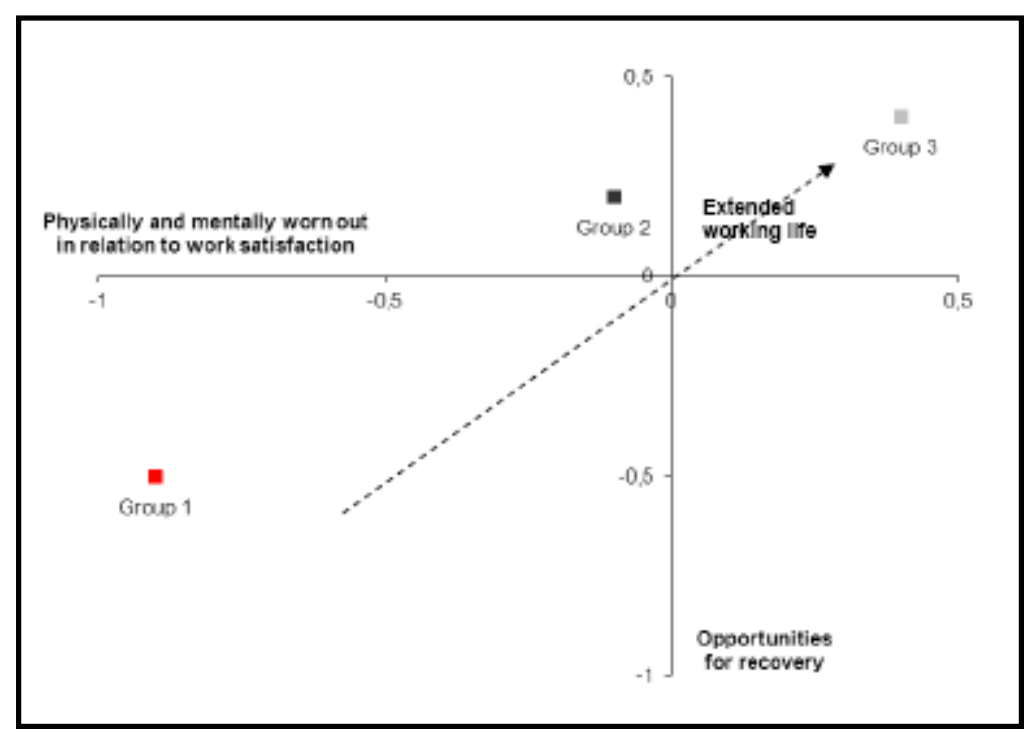

Figure 3. Position of the three groups evaluated as group means and equal peer groups. Group 1: Low self-rated health and with diagnosed disease (graph position: $-0.9 ;-0.5)$. Group 2: Low selfrated health with no diagnosed disease or high self-rated health with diagnosed disease (graph position: $-0.1 ; 0.2$ ). Group 3: High self-rated health and no diagnosed disease (graph position: 0.4; 0.4). (Source: Paper II). 


\subsection{Paper III: Demanding work environment and occupational injuries in old age}

In this study, about 4 per cent of the 5062 people surveyed had been injured in work-related accidents during one year. The injury fraction between the age groups was 4 per cent in age group 49 or below, 5 per cent of those aged 50-59, and 4 per cent of those aged 60 or above.

On average, 79 per cent of the injured had to seek medical help for the injury. However, there was no statistically significant difference between the age groups. There was also no statistically significant difference between the age groups that had taken sick leave due to injury (Figure 4).

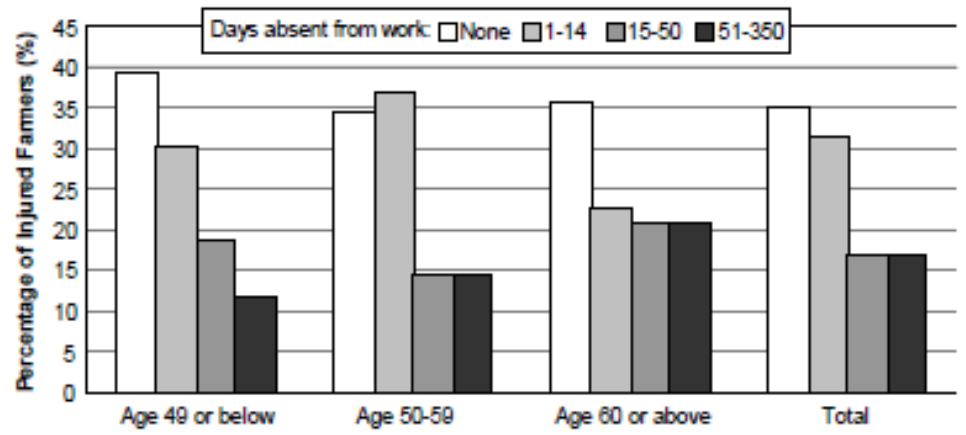

Figure 4. Percentage of injured Swedish farmers in different age groups missing different periods from work because of injury. Differences between the age groups are not statistically significant $(\mathrm{P}>0.05)$. (Source: Paper III).

The most common events leading to injury of the respondents in all age groups consisted of being hit or kicked by animals, followed by injuries involving moving vehicles and machines, and being hit by falling/flying or sharp objects (Figure 5). Hits or kicks by animals and vehicle injuries were particularly common in the oldest age group, but no statistic significant differences was found compare to the other age groups. 


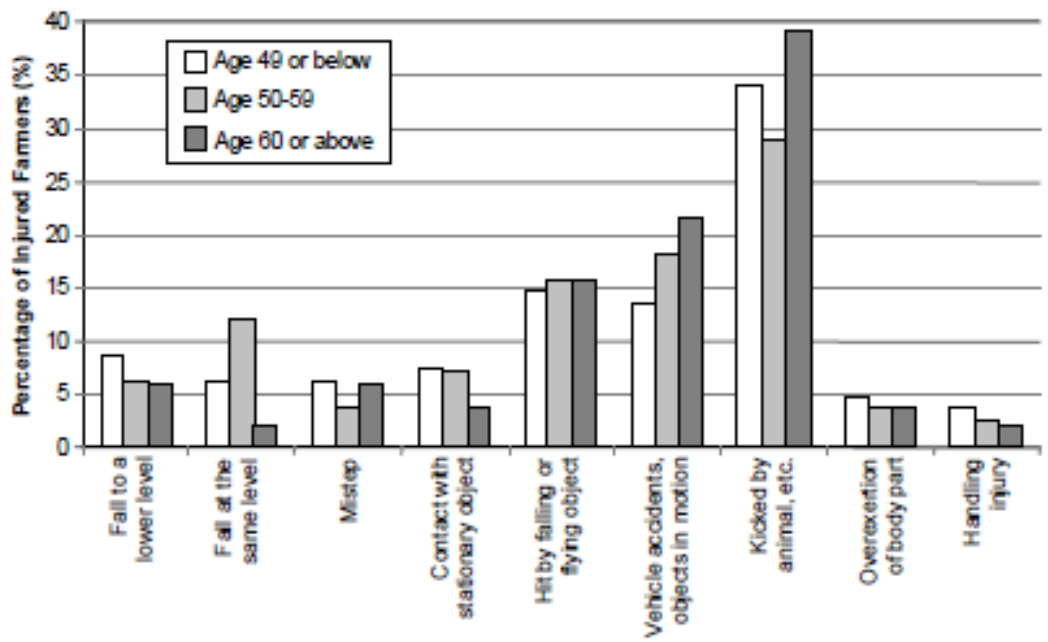

Figure 5. Percentage of injured Swedish farmers in different age groups suffering injuries due to different causes. Differences between the age groups are not statistically significant $(\mathrm{P}>0.05)$. (Source: Paper III).

Some parts of the body were more vulnerable than others. Skeletal injuries, crushed or pinched soft tissue injuries and bleeding wounds, in that order, were the most common injuries in the oldest age group. The most common parts of the body to be injured in all age groups were the hands-wrists-fingers, hipslegs-knees, and ankles-feet-toes, followed by head-face (Figure 6). For the oldest age group, the ankles-feet-toes were the most common parts to be injured in work-related accidents, but no statistic significant differences was found compare to the other age groups.

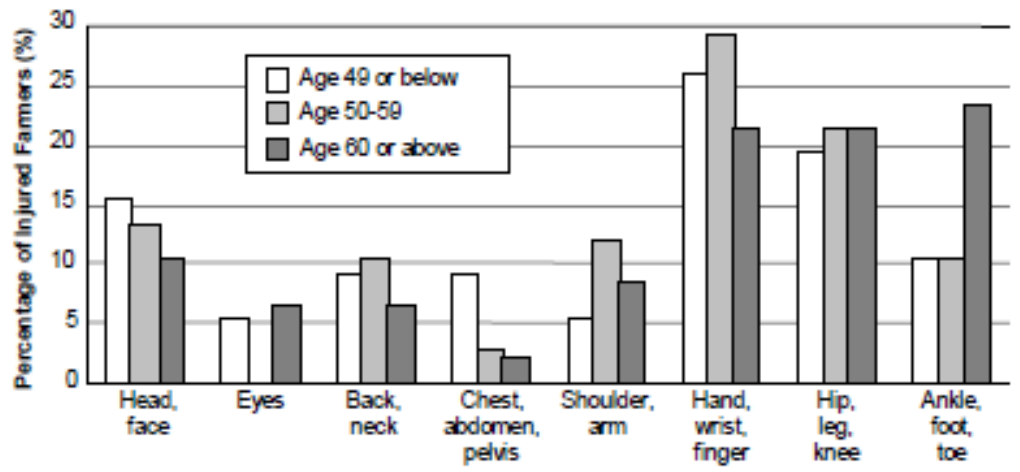

Figure 6. Percentage of injured Swedish farmers in different age groups suffering injuries to different parts of the body. Differences between the age groups were not statistically significant (P>0.05). (Source: Paper III). 


\subsection{Paper IV: The decision to continue working or retire early}

The discourses on work and retirement have different importance relating to older workers' identity, life and work situation and their attitude to their surrounding social environment. The analysis evaluated four themes as overarching in the interviewees' rational considerations and weightings before their decision to retire or extend their working life. These four themes were, in order of ranking by the interviewees: (i) personal health and well-being; (ii) personal finances; (iii) possibilities for social inclusion; and (iv) possibilities for self-crediting by meaningful activities (Figure 7). All the themes included in the model were considered and weighted together in the interviewees' decision making. Depending on the individual's situation, one or all four themes were described as the final reason for retirement or extended working life.

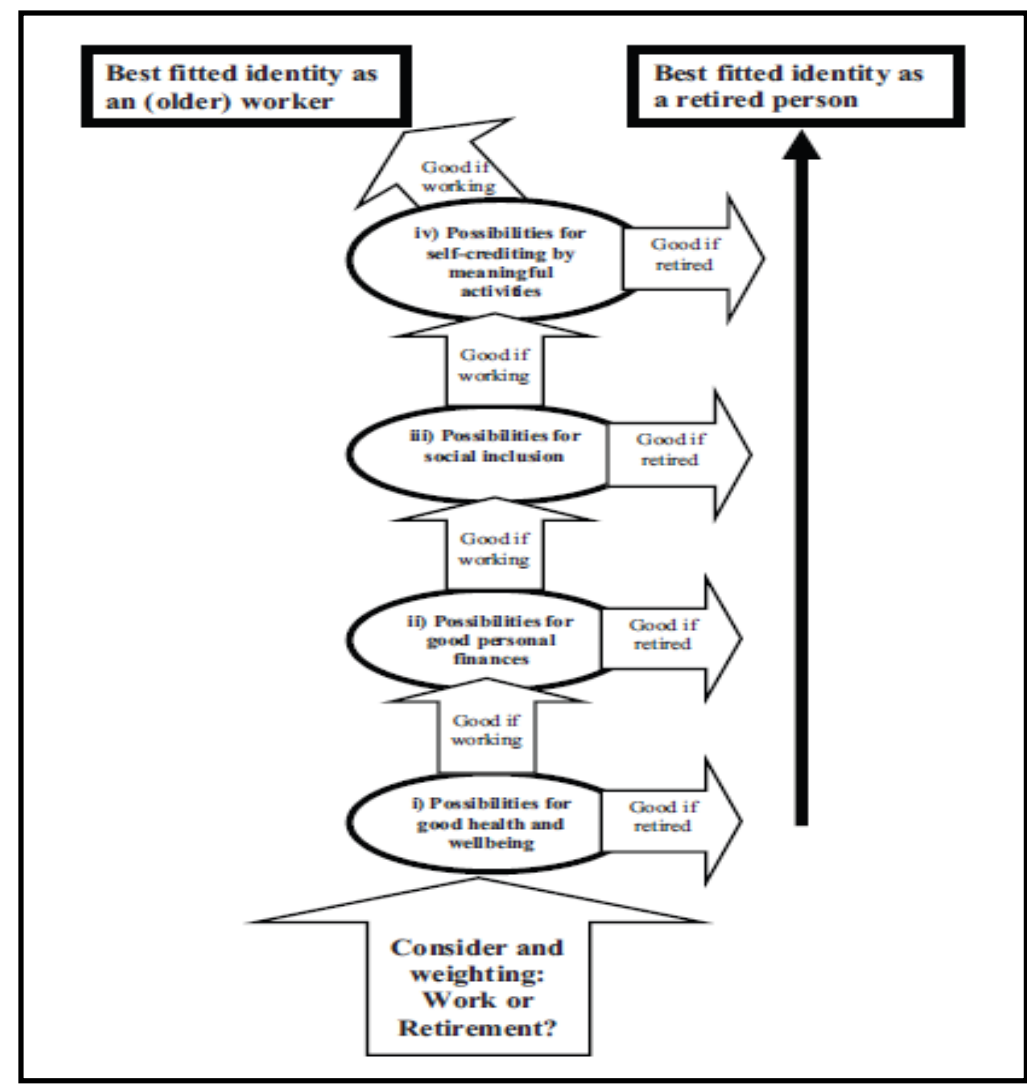

Figure 7. Model showing the interviewees' wordings about work and retirement and their rational considerations and weighting of the four themes to their own identity as an (older) worker or as a retired person. (Source: Paper IV). 


\subsubsection{Health}

Health problems seemed to determine whether interviewees were able to continue working. Some said that they were more tired nowadays and, as older people, needed more time for recovery. In addition, many interviewees noted that there was an attitude that "real men" did not use protective equipment and that this dominant attitude in their youth had influenced them to cease using protective equipment. Almost every one of the interviewees had experienced an incident that could have ended in disaster or had suffered injury at work. Their physically demanding work environment, carelessness with the use of protective equipment and failure to work in an ergonomically correct way had caused minor or major health problems. Being injured or working with the risk of injury was described by all interviewees as normal and a part of work.

However, some of the interviewees stated that health was the reason why they worked beyond 65 years of age. Actually, some of the interviewees with the greatest health problems were still working beyond age 65 and claimed that work helped them to stay active physically, mentally and socially, and prevented ill-health. They described it as a natural thing for the body to decline, but did not feel that they were mentally or socially too old to work. They also took breaks from work when they were fatigued in order to reduce the risk of accidents. Several also mentioned that their experience had increased with age and they now carried out their work in a better way and did not expose themselves to risks as much as earlier. They also reported that technological developments had meant that their work tasks were not as hazardous and demanding as before. Those who were self-employed farmers seemed to have possibilities to conform their working situation to fit their functional ageing.

\subsubsection{Personal finances}

Many of those who had left working life before 65 years of age described work as being only meaningful to pay the bills and earn a living. However, those interviewees who were in the position of having work they liked regarded the income they earned from their work as a bonus, and felt that the salary was not as important as the acknowledgment of their work. They claimed it felt secure and comforting to be able to leave working life just when they wanted and to have the pension as basic security. This power to choose boosted their feeling of well-being and made them decide to go on working past 65 in a spirit of good finances, empowerment and independence. 


\subsubsection{Social inclusion}

The interviewees mentioned that the possibility of being with their work mates or partner or working with their children was an important factor in deciding on retirement. They noted that most people cannot live without social connectedness and that some find that to be best inside working life and others outside working life. Those who had not liked their work in particular described work as an obstacle to being together with people they really wanted to be with and doing things they really liked to do. Some had been exposed to age discrimination and forced to leave working life. They found themselves in a position where their former status had decreased and no-one asked for their knowledge and skills any more.

Age is used as an inclusion/exclusion criterion, for example, in getting a job and having to retire due to age. Several of those who were working beyond 65 years of age noted that it was important to contribute to society and not be seen as an outsider or lazy. They said that an extended working life was the common attitude in their immediate circle of acquaintances and felt it was right to be involved in professional life as long as they had something to give. However, when we asked those who had left working life before 65 years of age why they think people in general retire early, many seemed to be uncomfortable with the question and overstated their health problems so as not to be seen as lazy. When we asked those for common reasons why some people work beyond 65 , almost all said that those people probably did not have a social life outside work.

\subsubsection{Self-crediting by meaningful activities}

All our interviewees who chose to work after 65 years of age described their work as meaningful and rewarding, something they wanted to continue with. They said that the opportunity to solve real problems gave them satisfaction and stimulation, and could not understand how those who took early retirement could pass the time without working or anything motivating to do.

Some of those who had left working life early reported that they had not been able to develop their skills and ambitions in their work. The quality of their work was no longer recognised and appreciated in the same way as before. Instead, quantity and economies of speed had become important. Some stated that if someone cares and appreciates what you do, you want to do it even better, but if no-one cares you stop caring too. New work situations in which 
managers no longer knew the employees, did not see employees as individuals, or were even unaware of what they did, and how, resulted in those employees becoming distanced from work. They said that this contributed to them no longer being able to control their work in the same way as before and feeling alienated in their work. Many said that work had been a barrier to doing more meaningful and satisfying things in their life and that they would have gladly stopped working even earlier if their finances had allowed it. 


\section{Discussion}

\subsection{A model to work or not to work in an extended working life}

The overall objective of this thesis was to contribute knowledge about older workers' own experiences and attitudes to their working life situation in association with their planning and decision on retirement. A model was developed from the results of Papers I-IV, earlier studies and theories (Figure 8). The background to the thesis was the general trend on the macro level in many Western societies and economies to increase the pension age. Less demanding working life, better social conditions, better work environments and medical improvements have resulted in people in general being healthier and living longer today, which advocates postponing the retirement age in the macro level perspective. In the meso level perspective, the attitude of organisations and managers, the need for and interest in older workers' experience and knowledge from a long working life, but also their ageing bodies and minds influence people's possibilities to extend their working life. According to this thesis, the factors that in the micro level influence older workers' possibility to work in relation to the macro and meso level can be sorted and classified into: basic premises for inclusion in working life including health, economic incentives, family and attitude in the surrounding society; hardware factors in work - including physical and mental work environment, competence and possibility for skills development, working pace and working time; software factors in work - including attitudes from managers and the organisation, motivation and work satisfaction (Figure 8). 


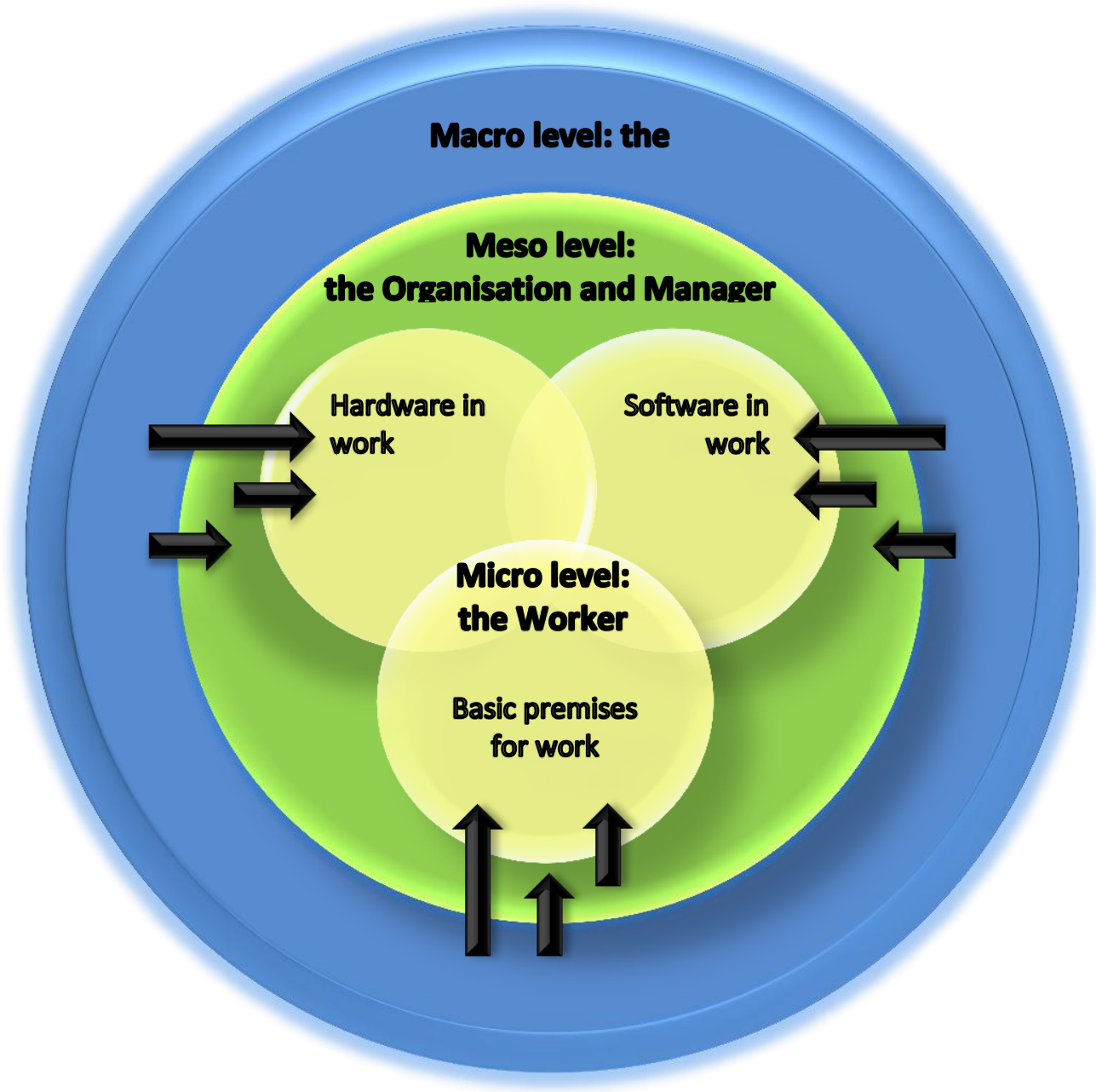

Figure 8. Model of different levels affecting individuals to work or not to work in an extended working life:

- Society, macro level: economic interests to maintain the welfare state.

- The organisation and managers, meso level: the organisation's costs and productions in relation to the workers' health and recuperation, tasks, competence, etc.

- The worker, micro level:

- Basic premises for work - includes health, economic incentives, family and attitude in the surrounding society.

- Hardware in work - includes physical and mental work environment, competence and possibility for skills development, working pace and working time.

- Software in work - includes attitudes from managers and the organisation, motivation and work satisfaction. 


\subsection{General discussion}

\subsubsection{Factors influencing whether older workers believe they "can" and "want to" extend their working life.}

People's age and ageing process are often relative to someone and something else. In addition, there is no such thing as a normal value or a general bestbefore date for workers. Therefore it is controversial to use only chronological age to establish the time to exit working life. However, this thesis found a statistically significant difference between whether people think they "can" or "want to" extend their working life. The studies showed the complexity in the retirement issue and that people in general think they "can work" until 65 years and beyond more often than they "want to work". In earlier research one or few different factors at a time were analysed in association with retirement and described as important. In the analysis we included nine areas identified as important to retirement planning from earlier studies and research: i) health; ii) economic incentives; iii) physical work environment; iv) mental work environment; v) work pace and working time; vi) attitude to older workers from managers and in the organisation; vii) competence and possibility for skills development; viii) motivation and work satisfaction; ix) family/leisure pursuits and attitude to pension in the surrounding society (see references in Appendix 1). The association of these nine areas to "can" and "want to" extend working life was in some ways different (Figure 9). Regarding the results in this thesis and earlier studies, the nine areas in retirement planning could be sorted into three important groups, i.e. a) basic premises for work, including health, economic incentives, family and attitude in the society to work, all associated with both "can work" and "want to work"; b) hardware in the work, including areas associated with whether people think they "can work", e.g. "mental and physical work environment", "working pace and working time", "competence and possibility to skills development"; c) software in work, including only areas associated with whether people "want to work", e.g. "attitude to older workers from managers and in the organisation" and "motivation and work satisfaction" (Figure 8).

Health, economic incentives and family/leisure pursuits and attitude to pension in the surrounding society were associated with both whether people think they "can" and "want to" extend their working life (Figure 9). Those areas seem to be the basic, fundamental areas for inclusion in working life and affect whether people both think they "can" and "want to" work. However, even though 
health was one of the basic areas for "can" and "want to" extend working life, it seems that other factors were more important. Economic incentives, family/leisure and attitude to pension in the society were more strongly associated with whether interviewees thought they could and wanted to work. This could be due to the total study population being still employed and their health not being too bad, even if some had sick leave or a partial disability pension. Their personal economic situation or the possibility to social inclusion in or outside work was therefore more important in their pension planning. The same statements were not included or most strongly associated in all areas (Table 2). Especially in the area "family/leisure pursuits and attitude to pension in society", the statement only associated with "want to work" seemed to be more in the direction of software factors in work, i.e. the attitude to retirement and extended working life in the social surroundings. In the area "health", the statement only associated with "can work" seemed to be more in the direction of hardware factors in work, i.e. worn out and poor health in relation to the work environment and work situation.

The other six areas were only associated with "can work" or "want to work". Whether older workers "wanted to work" or not was related to internal affected software factors in work, i.e. the areas "motivation and work satisfaction" and "attitude to older workers from managers and in the organisation" (Figure 9). Those areas could be compared with earlier studies which reported that work satisfaction, positive attitude from managers and engagement in work are motivational factors to work and increase productivity (Blauner, 1973; Gardell et al., 1979; Herzberg, 1966; Herzberg et al., 1959; Hirschman, 1970; Roethlistberger \& Dicksson, 1939). Whether older workers "can work" was related to hardware factors in work, i.e. "mental work environment" and "physical work environment", "working pace and working time", "competence and possibility to skills development" (Figure 9). Earlier studies have described working conditions and work environment, e.g. external work factors which prevent disease and discomfort in the work situation, but do not motivate the individual to work or increase productivity (Herzberg, 1966; Herzberg et al., 1959). However, factors such as economic incentives and attitude from managers were described as external "work hygiene" factors in those earlier studies, but were included in the basic premises for work and software factors in work in the model due to our results regarding "can work" and "want to work" (Figure 8).

The retirement issue is complex and people in general think they "can work" until 65 years and beyond more often than they "want to work". Despite about 
half the work force maintaining a moderate level of work ability to 63-65 years of age (Härmä, 2011; von Bonsdorff et al., 2011), about $80 \%$ of the work force still retires at age 65 or earlier in Sweden (SOU, 2012). Factors influencing individuals' retirement need to be better understand on the individual micro level if the official intention is to increase pension age. If an extended working life and an increasing number of older workers are desirable for the society, it is important to make the basic premises, hardware and software factors as suitable, attractive and motivating as possible to remain in the working life. It is important to consider both the "can" and the "want to" in the extended working life discussion, according to this thesis and earlier studies. However, the "can work" and "want to work" need to be investigated further in a prospective study to follow the long-term effects.

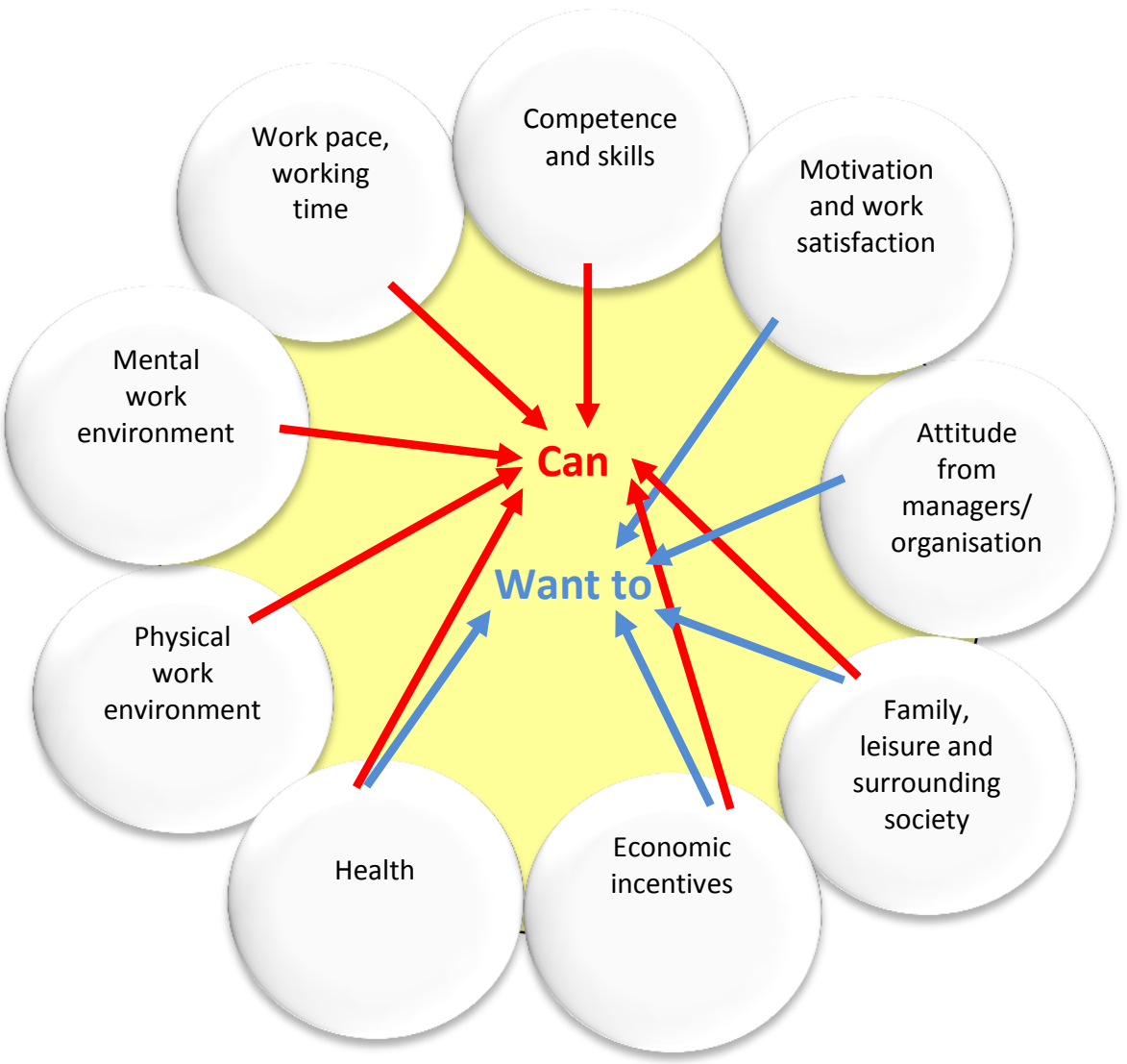

Figure 9. The nine areas associated with whether older workers believe they "can" or "want to" extend their working life. The red arrows show associations from the nine statements to whether older workers believe they "can work", while the blue arrows show associations from the nine statements to whether older workers "want to work". 


\subsubsection{Influence of factors associated with older workers diagnosed disease and self-rated health on retirement planning.}

Health was associated with both whether people "want to" and believe they "can" extend their working life and was included in the basic premises for work (Figure 8). Health has also been described earlier as important for the possibility for inclusion in working life or withdrawing from the work force (Bengtsson \& Nilsson, 2004; Holliday, 2010; Ilmarinen, 2003; Nilsson, 2005a; 2006; Nylén \& Torgén, 2002; Park, 2010; Park et al., 2012; Pit et al., 2010; Saurama, 2004; Seitsamo \& Klockars, 1997; Siegerist et al., 2007; Stattin, 1998; 2005; Taylor \& Shore, 1995; WHO, 2002). Health can be measured in different ways, e.g. objective diagnosed disease or subjective experienced selfrated health. Diagnoses and disease can be objectively stated by a physician, but subjective and personal health can only be stated by the individual. Both health measures examined in this thesis, i.e. diagnosed disease and self-rated health, were associated with the older workers' physical and mental wear, physical work environment, working pace and working time (Figure 10). Areas associated with diagnosed disease were basic premises for work and hardware factors in work (Figure 8). According to earlier research, those areas are also related to external work hygiene factors, which could prevent ill health or not (Herzberg, 1966; Herzberg et al., 1959). Self-rated health was also associated with the attitude to older workers in the organisation, motivation and work satisfaction (Figure 10), i.e. factors associated with basic premises for work, hardware and software factors in work (Figure 8). The self-rated health measure seemed thus to be related to external work hygiene factors, but also to work content factors which in earlier studies are reported to motivate people to work and increase productivity (Herzberg, 1966; Herzberg et al., 1959).

The results in our previous study and related earlier studies and praxis indicate that instead of only using diagnosed disease as a health measure, a combined health rating alos including self-rated health would be an alternative tool to assess individuals' working opportunity in relation to health. This due to diagnosed disease was not even significant after simultaneously including both health measures in the model to older workers retirement planning. The reason was probably that self-rated health in addition to fatigue from working life and possibility to recovery was also associated with the attitude to older workers, motivation and work satisfaction. Furthermore, self-rated health has been described as a better predictor of mortality than diagnosed disease (Idler \& Benyamini, 1997; Mossey \& Shapir, 1982; Singh-Manoux et al., 2007; Strawbridge \& Wallhagen, 1999). Self-rated health is also described as a better 
predictor of disability retirement (Karlsson et al., 2008; Karpansalo et al., 2004; Pietiläinen et al., 2011). On the other hand, diagnosed disease is a practically useful tool for treatment and rehabilitation in health and medical care. However, people may have a combination of diagnosed and undiagnosed disease, irrespective of high or low self-rated health, and therefore both health rates need to be considered in relation to ability to work.

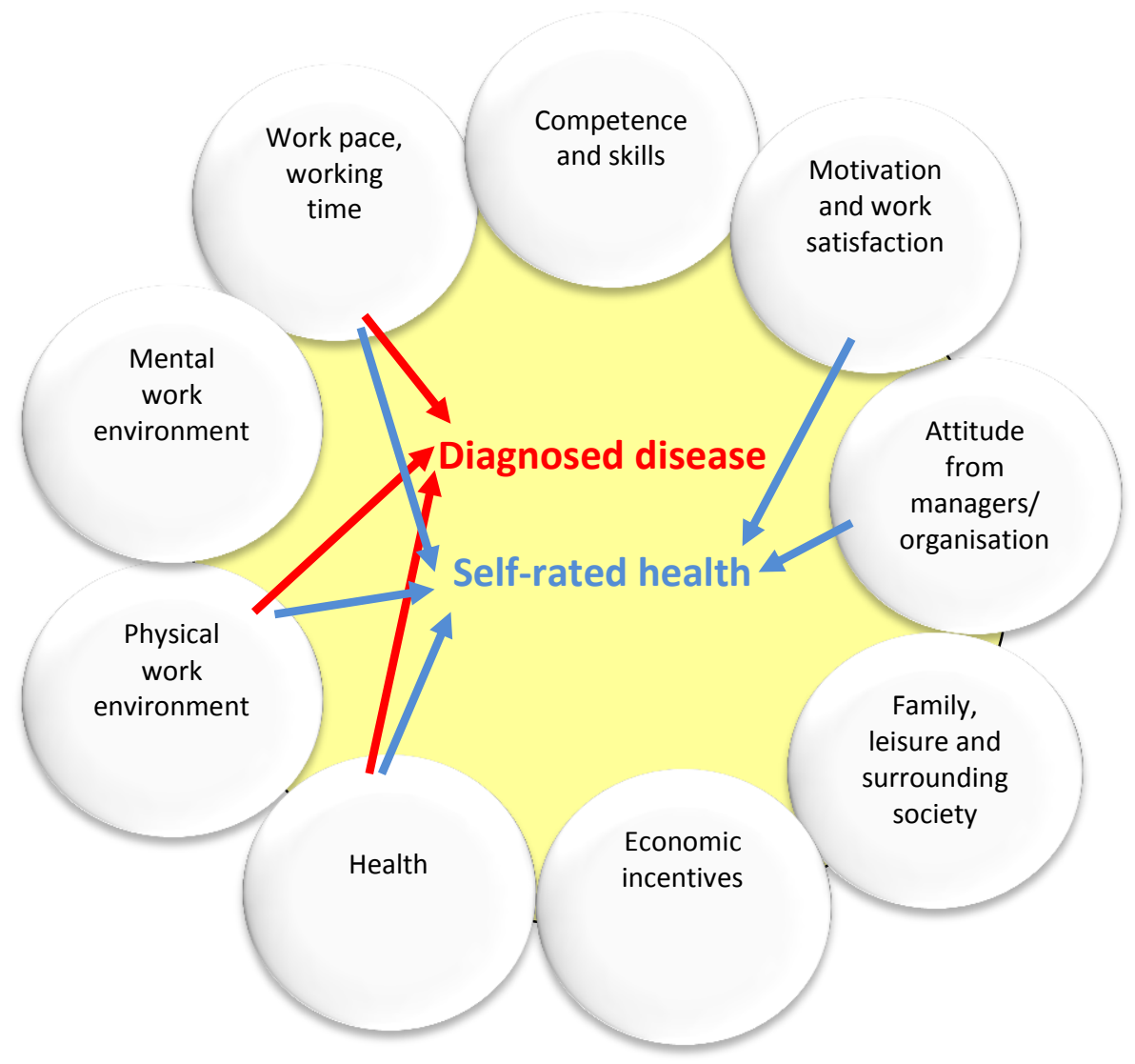

Figure 10. Areas associated with older workers' diagnosed disease and self-rated health among the nine areas identified. The red arrows show associations from the statements to "diagnosed disease", the blue arrows show associations from the statements to "self-rated health".

To analyse the health rating associations further, three new groups were created in the combination of diagnosed disease or not and high or low selfrated health. The most important factor for the combined health rating of older workers was whether their physical and mental state was in balance with their work satisfaction and they had enough time to recover if they were worn out. If 
they had enough time and possibility to recover and work was satisfactory, health in relation to work was not a general barrier to inclusion in working life in old age as a general perspective among older worker in this study. However it is important to note that the results indicate that older workers need a gentler work pace and more time to recover their health and worn out. Even if the variation in health status is huge between older workers (Holliday, 2010; Koolhaas et al., 2012; Laslett, 1991; Seitsamo \& Klockars, 1997), it is important to consider that half the workforce has not maintained a moderate level of work ability at age 63-65 years of age (Härmä, 2011; von Bonsdorff et al., 2011). Earlier studies have also found that older workers need more time to rest (Beehr, 1986; Forma et al., 2005; Grahn, 2003; Hallsten, 1996; Ilmarinen, 2006; Nilsson, 2003a; 2003b; 2005a; 2005b; 2007a; 2007d; Saurama, 2004; Taylor \& Shore, 1995). Health problems due to working life could be exaggerated, but may also be a real problem, especially if people experience a negative attitude to them and dissatisfaction at work (Beehr, 1986; Blekesaune \& Solem, 2005; Doyle et al., 2012; Forma et al., 2005; Höög, 1985; Höög \& Stattin, 1995; Ilmarinen, 2006; Karasek \& Theorell, 1990; Melin \& Wigaeus Tornquist, 2004; Nilsson, 2005a; 2006; Park, 2010; Dwyer \& Mitchell, 1999; Saurama, 2004; Siegrist et al., 2007; Stattin, 1998; Taylor \& Shore, 1995; Trist \& Bamforth, 1951). If older workers experience that work affects their health, early retirement is an important argument in the intention to increase, or not further decrease, health (Bengtsson \& Nilsson, 2004; Blakeley \& Ribeiro, 2008; Trist \& Bamforth, 1951). Earlier studies describe the importance of initiatives from the organisation and managers involving occupational health promotion to increase older workers' good health experience and possibility to extend working life (Crawford, 2011; McGoldrick \& Arrowsmith, 2001; Mykletun et al., 2012). Despite this, most initiatives from society today aiming to extend working life are related to financial incentives in the pension system (Danish Labour Market Commission, 2009; SOU, 2009), and many organisations and managers are not interested in taking their own initiative to retain older workers (Jensen \& Juul Møberg, 2012; Munnell et al., 2006; Nilsson, 2011a). According to this thesis and earlier studies, initiatives that: adjust the work tasks and pace of work to the capacity; provide time for rest and relaxation between working days; increase work motivation and satisfaction; and create a positive attitude to older workers among managers and organisations might be a holistic way to make it possible to increase the retirement age in association with older workers' health status. It seems also to be important that organisations, occupational health services and social services do not only use objective health measures such as diagnoses to measure ability to work. Instead, they need to use an objective and subjective 
health tool in a combined health measure, i.e. both diagnosed disease and selfrated health, in the dialogue with older workers and their possibility to extend working life.

\subsubsection{Demanding work environment and occupational injuries in old age}

The work environment is very important to people's health and therefore also to retirement planning and pension decision making. In this thesis, physical work environment was associated with whether people believe they "can" extend working life (Figure 9), and also with hardware in work (Figure 8). Physical work environment was also associated with both diagnosed disease and self-rated health. We therefore studied physically demanding work environments to investigate whether there was a difference in injuries and type of accidents between different age groups (Figure 11). We found no statistically significant differences between the incidence of injuries and sickleave between older and younger workers. The results are contrary to earlier studies which show that even if older farmers are not more frequently injured than farmers in other age groups, they seem to take a longer time to recover after an injury (Mitchell et al., 2002; Myers et al., 2009; Silverstein, 2008). According to official research and injury statistics, the elderly in general in the total population, and not only the working population, suffer more often from accidents than middle-aged persons (Danielsson, 2000; Räddningsverket, 2007). On the other hand, research has established that older people with ageincreased experience and knowledge seem to prioritise and organise their work in a better way than younger people (Hallsten, 1996; Mather, 2010; Nilsson, 2007c; Salthouse, 2000; 1996). Knowledge gained after a long working life probably leads to work in a way that avoids risks and dangerous situations and protects their health. However, before drawing conclusions from the present results, we have to consider that our study group was small, perhaps too small to show statistically significant differences between the groups. Another fact that needs to be considered is that fewer farmers in the oldest age group worked full time. Therefore, it is possible that they were not exposed to risks for as many hours as those in the younger age groups. Thus we do not know whether the injury frequency in relation to working hours was higher for older than younger farmers. Furthermore, only people in the work force were included in the survey, i.e. those who had stopped work or left farming after their injury were not included in the study population (the healthy worker effect). 


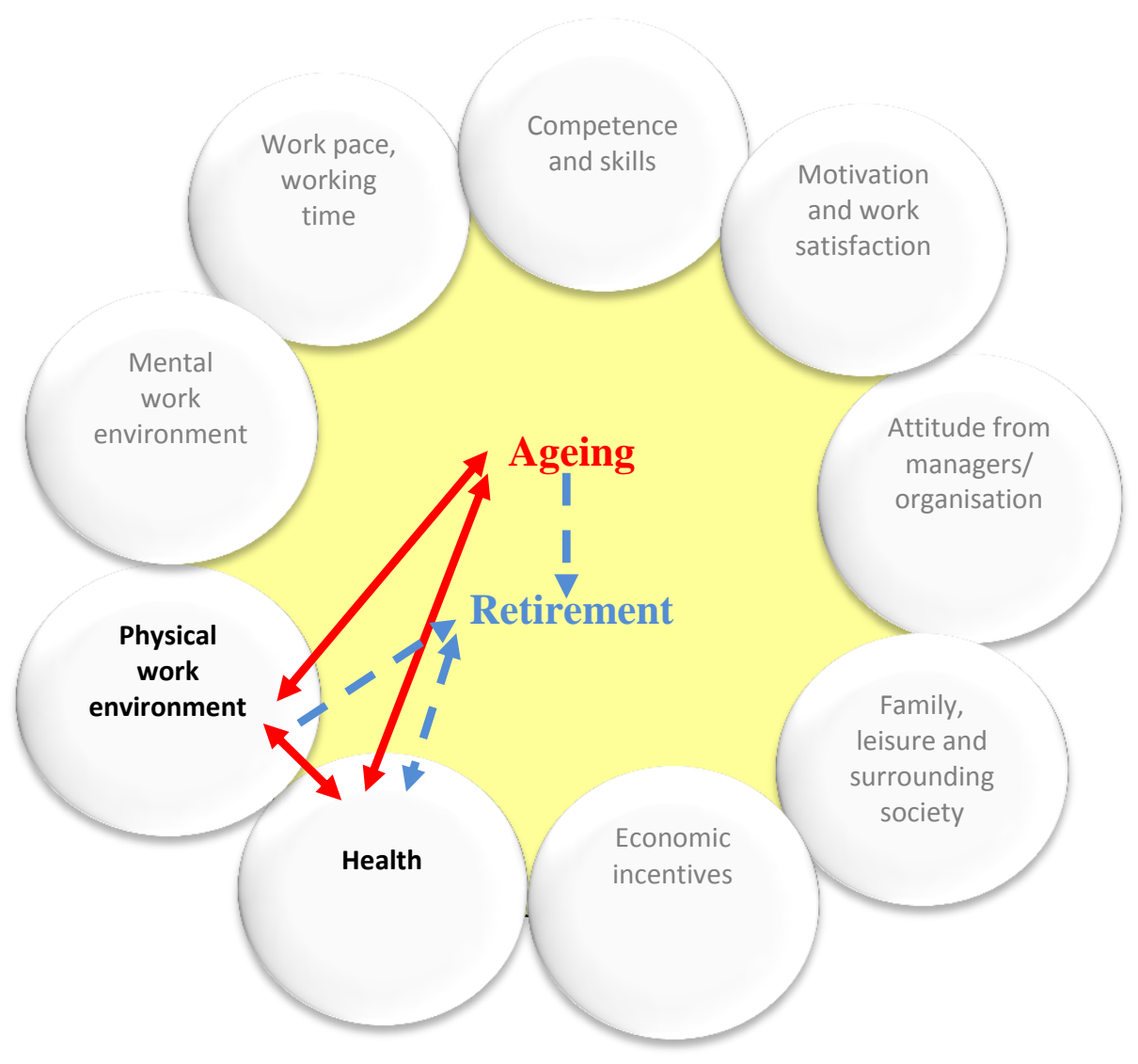

Figure 11. Relationship between physical work environment, health and ageing worker, but also the possible association with retirement in earlier studies and of interest in Paper III. The red arrows show the relationship between health/injury physical work environment and ageing and the blue dotted arrows the relationship between ageing, health and physical work environment and retirement.

The statutory retirement age is the same for all, irrespective of profession, but people in physically and mentally demanding occupations generally retire early from working life because of the nature of their work (Beehr, 1986; Canivet et al., 2012; Ilmarinen, 2003; Karasek \&Theorell, 1990; Kilbom \& Torgén, 1996; Nilsson; 2006; 2007d; Pohjonen, 2001; Sauré \& Zoabi, 2011; Siegrist et al., 2007; Stattin, 2005; Westerlund et al., 2009). We know that some professions are more hazardous than others, and that farming is one of the most demanding 
professions in Sweden. All age groups need to take care and actively reduce the risk of work accidents. However, many farmers work until they reach an advanced age and continue to work even when they are injured or ill (Hernandez-Peck, 2008; Reed et al., 1998; 2008; Voaklander et al., 1999). It is recommended that older workers consider that ageing in general accumulates risk factors such as decreased vision, hearing and musculoskeletal function that develop as a result of the natural ageing process and previous injuries (Gueorguieva et al., 2009; McLaughlin \& Sprufera, 2011; Mitchell et al., 2002; Myers et al., 2009; Pohjonen, 2001; Saure'\& Zoabi, 2011; WHO, 2002). Abrupt retirement after work accidents without giving older workers the option for self-empowerment could also affect their mental health negatively (De Vaus et al., 2007; Nylén \& Torgén, 2002; Torgén et al., 2001). With education, information and changes in the working process, the injury risk and disease can decrease (Blahey, 2002). It is therefore desirable to consider the risks and fit the work environment to older workers' capacity, fatigue and functionally ageing bodies.

\subsubsection{The decision to continue working or retire early}

In Sweden the retirement age is flexible between 61-67 years of age and the decision to retire involves considering and weighting factors for and against retirement. A decision model to retire or to extend working life for the individual worker was developed here (Paper IV). The interviewees placed their negative and positive associations to work and retirement in relation to their own life and work situation and weighed them to achieve their own best life balance, which resulted in their identity as (older) worker or retiree. The decision was based on the older workers' possibility to balance and adapt: i) their health in relation to the work situation and work environment, ii) their economic situation, iii) their possibility for social inclusion in a positive coherence, and iv) their possibility to carry out meaningful activities. The nine areas from the mind view of the thesis were found to be clustered into four themes in the decision making (Figure 12). Whether the basic premises for work, hardware and software in work (Figure 8) after the consideration of the four themes best fitted in or outside working life determined the interviewees' identity as older worker or early retiree. In the decision, the four themes needed to be good enough or suitable if people were to extend their working life.

i) Statutory retirement was introduced to make it possible to withdraw from working life when functional ageing and health problems make it impossible to 
make a living. The hardware in work seemed to be considered in relation to the interviewees' self-rated health. The early retirees described work as an activity that crushed health and increasing functional ageing for themselves and for people in general. Earlier research also found that a demanding work environment and occupational injuries are important contributors to ill-health and retirement (Bengtsson \& Nilsson, 2004; Grahn, 2003; Gueorguieva et al., 2009; Hallsten \& Solem, 1996; Ilmarinen \& Louhevara, 1999; Munnell et al., 2004; Nilsson, 2003a; 2003b; 2005a; 2005b; 2006; OECD, 2006; Pohjonen, 2001; Seitsamo \& Klockars, 1997; Volkoff ,1998; Warr, 1994; Westerlund et al., 2009). Ill-health has also been identified earlier as a socially acceptable way to withdraw from working life (Dwyer \& Mitchell, 1999; Trist \& Bamforth, 1951; Wikman \& Marklund, 2003). Those of our interviewees who disliked their work and work situation seemed to exaggerate the importance of their health problems for their retirement. However, those interviewees who enjoyed their work downplayed their health problems in their storyline and reported that working contributed more positively to their health than retirement, despite working within similar environments to those who had retired early. It was interesting that those with the worst chronic health problems in this study were working beyond 65 and regarded their work as a health promoter that kept them mentally and physically active.

ii) The Swedish pension system is now designed to encourage people to work longer by increasing the pension benefits for those who work to 67 years (RFV, 2004; SOU, 2012). However, those in our study who disliked their work, or believed their life would be better in retirement, left working life as soon as they had the financial possibility to do so, despite the incentive in the pension system. The risk of lower income is described as keeping people in work (Beehr, 1986; Bidewell et al., 2006; Bösch-Supan, 2000; Cobb-Clark \& Stillman, 2009; Coppola \& Benita Wilke, 2010; Forma et al., 2005; Höög \& Stattin, 1995; Nilsson, 2005a; 2006; Roberts et al., 2010; Soidrie, 2005; Stattin, 1998; 2005; Trist \& Bamforth, 1951). On the other hand, salary itself does not give work motivation (Herzberg, 1966; Herzberg et al., 1959; Hult \& Stattin, 2009; Wang \& Shultz, 2010). Those interviewees who expressed problems with hardware factors and software factors in work therefore reported that they left their work as soon as they believed their retirement to be economically suitable.

iii) Those in our study who described high social inclusion together with work mates and important others in work rated work higher than retirement. Others reported being vulnerable in work and getting better benefits from leisure and 
possibility of inclusion in a social group outside working life, e.g. in the family, leisure and voluntary activities. Some of those also claimed that their former working life involved alienation, lack of control and lack of respect and consequently rated retirement higher than work. Earlier studies and theories have noted that social isolation in the work place makes people withdraw from the situation (Beehr, 1986; Bidewell et al., 2006; Forma et al., 2005; Park, 2010; Siegrist et al., 2007; Taylor \& Shore, 1995). Social inclusion in work is an important software factor in work, but also in family, leisure and attitude in the surrounding society in the basic premises to work (Figure 8). However, history and culture also govern people's attitude regarding when it is morally and officially required to leave working life. Ageing and being retired were mentioned as a stigma by some of those still working, in that pensioners are no longer part of the age elite in the workforce, but marginalised. Age has frequently been reported as an inclusion criterion not only for working life, but also as an excuse to withdraw from an unsuitable working life (Bengtsson \& Nilsson, 2004; Glover \& Branine, 2001; Höög \& Stattin, 1995; McGoldrick \& Arrowsmith, 2001; Nilsson, 2011b; Dwyer \& Mitchell, 1999; Stattin, 1998; Wikman \& Marklund, 2003). Some of our interviewees also had a "them and us" attitude to their identity as an early retiree or older worker. Some also seemed to need to reinforce their own decision on early retirement and defend themselves against perceptions of being unproductive.

iv) Meaningful work was the last theme considered in the interviewees' decision making and was also an important software factor in work. Lack of interesting work activities, alienation and distancing from work due to reorganisation, new technology and bureaucracy were described as important reasons to stop working. This confirmed previous findings that powerlessness, performing unappreciated work, depersonalisation of work and lack of scope to express individual potential and personality reduced self-respect and status, and increased the willingness to leave working life (Bidewell et al., 2006; Blauner, 1973; Cobb-Clark \& Stillman, 2009; Forma et al., 2005; Gardell et al., 1979; Higgs et al., 2003; Hirschman, 1970; Karasek \& Theorell, 1990; Molinié, 2005; Nilsson, 2004; 2005a; 2005b; 2006; 2007d; 2011a; 2011b; Roethlisberger \& Dicksson, 1939; Saurama, 2004; Schnalzenberger et al., 2008; Solem et al., 2001; Trist \& Bamforth, 1951). On the other hand, those interviewees who experienced empowerment in their work situation and could control and suit their working day to their functional ageing wanted to go on working for many years and believed they could do so. In addition, they described work activities as much more motivating and worthy than leisure activities. Work places where people want to work, enjoy, feel included and 
have scope for self-organisation, satisfaction, empowerment and appreciation have been described as healthy (Aronsson \& Lind, 2004; Bengtsson \& Nilsson, 2004; Gardell et al., 1979; Herzberg, 1966; Herzberg et al., 1959: Karasek \& Theorell, 1990; Nilsson, 2004; Siegrist et al., 2007; Thelander, 2003). Healthy work places increase the possibility to go on and work for older and younger workers. However, today few organisations and managers take their own initiative or are interested in keeping their older workers (Jensen \& Juul Møberg, 2012; Munnell et al., 2006; Nilsson, 2011a), and incentives need to be created by society to increase employers' interest in keeping older workers in the work force.

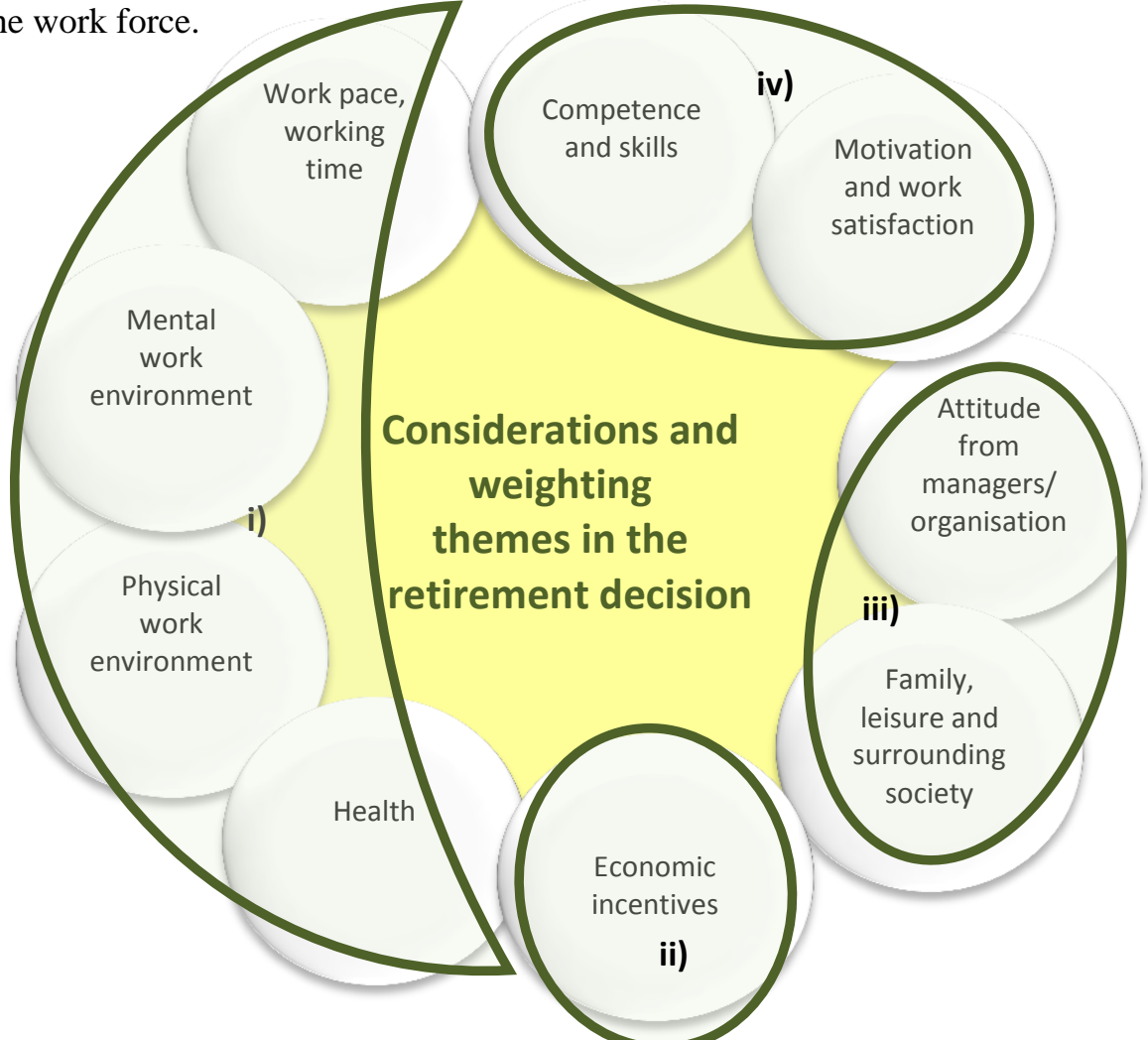

Figure 12. Rating of considerations and weighting themes in retirement decisions among the interviewees as related to the nine areas: i) their health compared with the work situation and work environment, ii) their economic situation, iii) their possibility for social inclusion in a positive coherence, and iv) their possibility to meaningful activities. 


\subsection{Methodological considerations}

The study population in Papers I-IV was limited to Swedish workers and to nine different professions in health and medical care, farmers and rural dwellers in varied occupations. Therefore we do not know whether the results would be different for other groups. However, the results and the studies developed out of earlier studies and, compared against other studies and theories, seem to be relevant in a broader view.

The study design in Papers I-II was cross-sectional, and the results should be interpreted as the workers' own attitudes and predictions about extended working life/retirement planning. If the study design had been longitudinal, we could have investigated whether the results of the association with older workers' opinions on whether they could and wanted to work also affected their decisions to retire. However, the results from these cross-sectional studies could generate hypotheses for future studies. The questionnaire was performed after a focus group study and a review of the theoretical basis in the area and the majority of the statements in the questionnaire were previously validated in other surveys. In addition, a pilot study was performed to ensure that the statements included and fulfilled the objectives. Although we had a relatively large number of participants in the study, a potential weakness was that $36 \%$ of the individuals in the original study population did not participate. Unfortunately, it is not possible for us to estimate the non-respondents and their importance because we have almost no information about them. However, according to information from the diary used when people called to state that they did not want to participate, the most common reasons for nonparticipation seemed to be health and conflicts with managers. We do not know whether this affected the results.

It is critical to bear in mind that everyone included in the study population in Papers I-III was employed. There could therefore be a healthy worker effect and selection bias if those with poor health had already left the work force. On the other hand, we used individuals working in the same work force, and internal comparisons are reported to be one of the most effective ways of reducing the healthy worker effect ( $\mathrm{Li} \&$ Sung, 1999). The respondents were mostly women occupied in professions in the health and medical care sector, although there were fewer women among the doctors responding. Thus the study population consisted mostly of women, but that reflects the reality in the healthcare sector and the models were robust even after adjusting for gender. 
The models were also robust after adjusting for age and marital status, so we do not regard this as a major shortcoming in the study.

A strength in Paper I was the possibility to determine differences between whether older workers believed they "can" and whether they "want to" extend their working life. All nine areas in the analysis had been identified in earlier studies as very important to retirement and retirement planning, but not all had been included in the same study. Furthermore, to the best of our knowledge earlier studies had made no distinction between whether older workers believed they "can" and/or "want to" extend their working life.

The main strength of Paper II was the possibility to determine differences between whether older workers self-rated health and diagnosed disease in association with all nine areas identified in earlier studies as very important for retirement and retirement planning. Furthermore, to the best of our knowledge earlier studies had made no distinction between self-rated health and diagnosed disease as health measures in association with older workers' opinions on whether they can extend working life.

Paper III was cross-sectional, with the focus on occupational injuries during one year. A limitation in the study was that we do not know if the respondents remembered and reported minor accidents and injuries in the mail survey. Furthermore, it was only persons active in the work force who participated in the study. Therefore there could be a healthy worker effect and selection bias if those with severe injuries had already left the work force. A strength in Paper III was that the respondents were representative of farms in Sweden and only $19 \%$ did not respond to the mail questionnaire after two reminders. The nonrespondent analysis including telephone interviews showed no particular differences between respondents and non-respondents.

The study design in Paper IV was semi-structured interviews. A limitation with interviews could be that people answered as they thought they should. Being asked in an interview about why they and people in general retired early may have made some feel defensive about their decision. On the other hand, those working after 65 years of age viewed their older worker identity as being of high status and almost heroic in society. This could also be a reaction to being interviewed on this subject, as questions regarding work and retirement could include a social code of being good enough, hard-working and part of the elite. A limitation was the low number of participants in the interview study (22), but already after 15 interviews the pattern was clear and the last interviews did not 
give any new knowledge. The investigation did not seek to provide a complete picture of the total complexity of retirement, but to illustrate the process of retirement decisions and people's self-perceived identity as early retiree or older worker. Furthermore, the cohort from which the interviewees were drawn only included men. We therefore do not know if the results would have been the same if women had been included in Paper IV. Those who refused to participate in the interviews cited lack of time and lack of interest as reasons, but we do not know any more about their everyday situation. A strength of the semi-structured interview design in Paper IV was the informants' possibility to describe their situation and decision making in their own words, without the risk of missing subjectivity by limiting them to specific questions. 


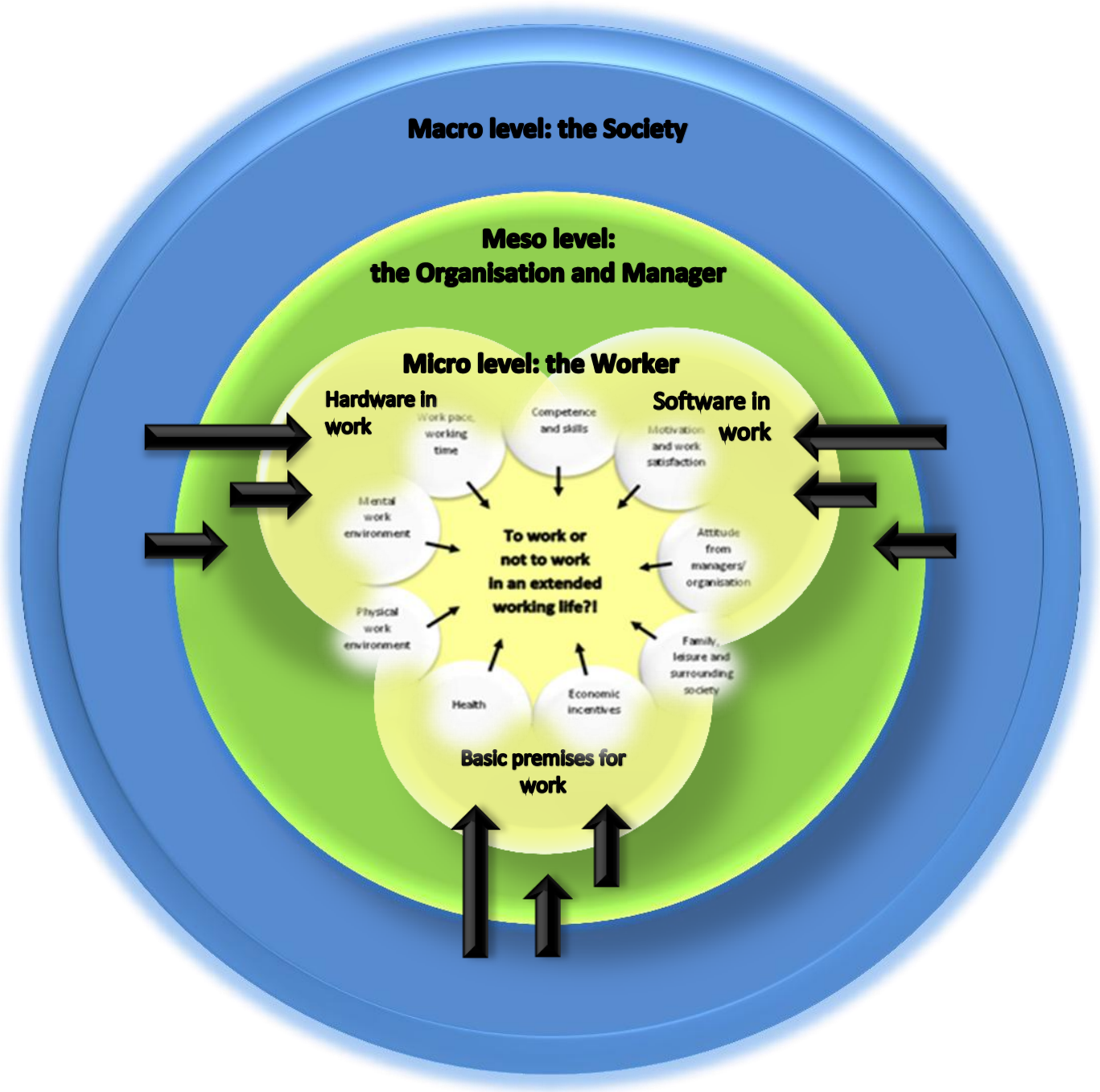

Figure 13. Model of different levels affecting individuals to work or not to work in an extended working life:

- Society, macro level: economic interests to maintain the welfare state.

- The organisation and managers, meso level: the organisation's costs and productions in relation to the workers' health and recuperation, tasks, competence, etc.

- The worker, micro level:

- Basic premises for work - includes health, economic incentives, family and attitude in the surrounding society.

- Hardware in work - includes physical and mental work environment, competence and possibility for skills development, working pace and working time.

- Software in work - includes attitudes from managers and the organisation, motivation and work satisfaction. 


\section{Conclusions}

In most of the industrial word the fraction of older and retired persons in the population is continuously increasing. This will have budgetary implications at the macro level for maintaining the welfare state, because the active working sector of the population funds the non-active and old sector. However, the possibility for older workers to extend working life is also influenced on the organisational meso level and the older workers' own individual micro level (Figure 13). The main conclusions from the work presented in this thesis are:

$\checkmark$ Factors that influence both whether older workers "can" and "want to" continue working need to be suitable if more people are to extend their working life.

Economic incentives, health, family and attitude in the surrounding society are the basic and decisive premises which must be good in relation to working life if people are to extend working life. Hardware factors in work are associated with whether older workers "can" extend working life, e.g. physical and mental work environment, competence and possibility for skills development, working pace and working time. Software factors in work are associated with whether older workers "want to" extend working life, e.g. internal motivational issues such as positive attitude from managers and the organisation, motivation and work satisfaction.

$\checkmark$ A holistic health rate tool including both diagnosed disease and self-rated health is the best measure of whether older workers can extend working life in terms of their health.

Health can be rated as diagnosed disease or self-rated health and is among the basic premises for inclusion in working life. However, self-rated health but not diagnosed disease was statistically significant when both health ratings were included in the analysis. The result in this thesis confirm that diagnosed disease is too blunt a health measure, and therefore self-rated 
health also needs to be included in investigations and discussion of opportunities to extend working life.

$\checkmark$ There are no major differences in the incidence of work injuries between different age groups in one of Sweden's most dangerous work environment. The differences between work injury rates among older and younger farmers were not statistically significant.

$\checkmark$ The decision to continue working or retire is based on whether health, personal finances, social inclusion and meaningful activities are best fitted inside or outside working life.

People's decisions are often based on considerations to get the best out of a situation. The "can" and "want to" perspective was evident in this thesis. The final retirement decision among older workers seemed to be based on the possibility to balance and adapt functional ageing and health to a sustainable work situation and to adapt physical and mental worn out to work satisfaction and opportunity for recovery. Economic incentives were the second important theme in the pension decision and were included in the basic premises for work. However, the economic incentives were not described by respondents as motivating them to extend working life, but to earning a living and being able to afford to perform motivational and meaningful activities and to buy things. The third consideration was whether inclusion in a positive social coherence was best inside or outside working life. The fourth consideration was whether continued working or retirement gave the best opportunities for motivational and meaningful activities. The older workers considered and weighted the four themes inside the basic premises for work, the hardware factors and software factors in work at their micro level and in relation to the meso level and macro level in their pension decision.

If society's intention is to postpone retirement age, in the macro approach of stabilising and maintaining the economy of the country, there is a need to raise awareness at the micro level so older workers can and want to still play an active role in working life and enjoy good health with quality of life. It is therefore important to consider the basic premises for work, hardware in work and software in work and provide a good fit to older workers' micro level inside working life. However, the challenge in this seems also to be at the meso level, among organisations and managers, and in raising their interest in keeping older workers and sometime finding alternative work tasks. To promote extension of working life, policy programmes need to be devised and implemented in organisations, including a combination of the dimensions: health promotion and prevention in work places; work environment and working arrangements; work-life balance; changing attitude and social support 
for older workers. A good active ageing policy needs to start early as a part of human resource management (HRM) in order to reduce demanding work situations in people's early work career so as to decrease health problems later, and to increase the possibility to work control and to fit the work situation to workers' functional ageing.

\subsection{Future research}

It is important to develop tools to adapt the work environment to older workers in relation to the organisational meso level and the social macro level. A future research need is to examine "can work" and "want to work" in a longitudinal study to investigate these aspects over the long term.

This thesis mostly examined health and medical care personnel and farmers, but different occupations probably have different demands. Today we do not know if it is possible or even desirable to postpone the retirement age for all people in all occupations. Does the possibility to extend working life vary with occupation? Are some occupations too demanding to extend the working life?

Men and women address different situations from cultural, status and biology preferences compared with work and family. Men's and women's challenges and opportunities to extend working life in relation to leisure activity need therefore to be investigated separately. We also need to examine whether there are gender-related consequences in different professions that influence health, retirement and life expectancy.

Health is associated with physical wear and possibility for recovery among older workers. It would therefore be interesting to further investigate age management programmes, including working time and work pace.

It is also important to develop and investigate different intervention programmes to encourage older workers to remain in work, including: health promotion and prevention in work places; work-life balance; work environment arrangements; changes in work tasks during working life; lifelong learning; and a change in attitudes to older workers. 


\section{References}

Abrahamsson B. Aarum Andersen J. 2000. Organisation - att beskriva och förstå organisationer. [Organisations - to describe and understand organisations.] Malmö, Libers Ekonomi. (in Swedish.)

Abrahamsson K. Bradley G. Brytting T. Eriksson T. Forslin J. Miller M. Söderlund B. Trollestad C. 2003. Friskfaktorer i arbetslivet. [Healthy factors in working life.] Stockholm, Prevent. (in Swedish.)

Ahola K. Sirén I. Kivimäki M. Ripatti S. Aromaa A. Lönnqvist J. 2012. WorkRelated Exhaustion and Telomere Length: A Population-Based Study. 7(7):e40186. doi:10.1371/journal.pone.0040186

Anderson KH. Burkhauser RV. Quinn JF. 1986. Do retirement dreams come true? The effect of unanticipated events on retirement plans. Industrial \& Labor Relations Review, 39:518-526. doi:10.2307/2523244.

Andersson-Felé L. 2002. När gamla vårdar ännu äldre. [Whan older care for elderly.] Göteborg, Förvaltningshögskolan. (in Swedish.)

Arbeidsdepartementet Norway. Pension reform. http://www.regjeringen.no/nb/dep/ad/kampanjer/pensjonsreform/no/spors mal-og-svar.html?id=86829\#02 (cited 26 June 2012) (in Norwegian.)

Aronsson G. Lind T. 2004. Långtidsfriskas arbetsvillkor. En populationsstudie [Long time healthy working life. A population study.] Arbete och hälsa 2004:10. Stockholm, Swedish National Institute of Working life. (in Swedish.)

Artazcoz L. Cortés I. Borrell C. Escribà-Agüir V. Cascant L. 2010. Gender and Social Class Differences in the Association between Early Retirement and Health in Spain. Women's Health Issues, 20(6):441-447.

Backes-Gellner U. Schneider MR. Veen S. 2011. Effect of Workforce Age on Quantitative and Qualitative Organizational Performance: Conceptual Framwork and Case Study Evidence. Organisational Studies, 32(8):11031121. 
Beehr TA. 1986. The process of retirement: a review and recommendations for future investigation. Personnel Psychology, 39:31-55.

doi:10.1111/j.1744-6570.1986.tb00573.x.

Beehr TA. Glazer S. Nielson NL. Farmer SJ. 2000. Work and Nonwork

Predictors of Employees' Retirement Age. Journal of Vocational

Behaviour, 57:206-225. doi:10.1006/jvbe.1999.1736.

Bengtsson E. Nilsson K. 2004. Äldre medarbetare. [Older worker.] Malmö,

Swedish National Institute of Working life. (in Swedish.)

Bengtsson T. Scott K. 2010. The Aging Population. In Bengtsson T (ed.)

Population Aging - A threat to the Welfare state? Demographic Research

Monographs. Berlin, Springer-verlag.

Bidewell J. Griffin B. Hesketh B. 2006. Timing of retirement: Including a delay discounting perspective in retirement models. Journal of Vocational Behavior, 68:368-387.

Blahey GG. 2002. Making Farming Safe for Senior Farmers. Center of Aging. Canada, University of Manitoba.

Blair A. Sandler D. Thomas K. Hoppin JA. Kamel J. Coble J. Lee WJ.

Rusiecki J. Knott C. Dosemeci M. Lynch CF. Lubin J. Alavanja M. 2005.

Disease and Injury Among Participants in Agricultural Health Study.

Journal of Agricultural Safety \& Health, 11(29):141-150.

Blakeley J. Ribeiro V. 2008. Are nurses prepared for retirement? Journal of Nursing Management, 16:744-752.

Blekesaune M. Solem PE. 2005. Working Conditions and Early Retirement. A prospective Study of Retirement Behaviour. Research on Aging, 27(1):330. doi: $10.1177 / 0164027504271438$.

Boorse C. 1977. Health as a Theoretical Concept. Philosophy of Science, 44: 542-573.

Borglin G. 2005. Quality of life among older people. Their experience, need of help, health, social support, everyday activities and sense of coherence. Lund, Department of Health Sciences Lund University.

Brenes-Comacho G. 2011. Favourable changes in economic well-being and self-rated health among the elderly. Social Science \& Medicine, 72(810):1228-1235.

Blauner R. 1973. Alienation and Freedom. Chicago, University of Chicago Press.

Bruzelius LH. Skärvad P-H. 2000. Integrerad organisationslära. [Integrated organisational science.] Lund, Studentlitteratur. (in Swedish.)

Burr V. 1995. An Introduction to Social Constructionism. London, Routledge.

Börsch-Supan A. 2000. Incentives effects of social security on labor force participation: Evidence in Germany and across Europe. Journal of Public Economics, 78:25-49. doi:10.1016/S0047-2727(99)00110-3. 
Börsch-Supan A. Brugiavini A. Croda E. 2009. The role of institutions and health in European patterns of work and retirement. Journal of European Social Policy, 19:341-358.

Canivet C. Choi BK. Karasek R. Moghaddassi M. Staland-Nyman C. Östergren P-O. 2012. Can high psychological job demands, low decision latitude, and high job strain predict disability pensions? A 12-year followup of middle-aged Swedish workers. International Archive Occupational Environmental Health, online first. doi 10.1007/s00420-012-0766-4.

Carter N. Ulfberg J. Nyström B. Edling C. 2003. Sleep debt, sleepiness and accidents among males in general population and male professional drivers. Accident Analysis \& Prevention, 35:613-617.

Cheung F. Wu AMS. 2012. An investigation of predictors of successful aging in the workplace among Hong Kong Chinese older workers. International Psychogeriatrics, 24(3):449-464.

Cobb-Clark DA. Stillman S. 2009. The Retirement Expectations of Middleaged Australians. The Economic Record, 85(269):146-163. doi:10.1111/j.1475-4932.2009.00543.x.

Coppola M. Benita Wilke C. 2010. How sensitive are subjective retirement expectations to increases in the statutory retirement age? The German case. Mannheim, Mannheim Research Institute for the Economics of Ageing, 207.

Christensen T. Lægreid P. Roness PG. Róvik KA. 2005. Organisationsteori för offentlig sector. [Organisational theory to public service.] Malmö, Liber Ekonomi. (in Swedish.)

Crawford JO. 2011. Health, Safety and Health Promotion; Taking Evidence into Practice. In Ennals R. Salomon RH. (eds.) Older Workers in a Sustainable Society: 67-78. Frankfurt, Peter Lang Verlag.

Danielsson K. 2000. Vilka skadar sig i hemmet? Och hur? - data från EHLASS- registret. Rapport 2000:26. [Who has been injured at home? And how? Report EHLASS 2000:26.]. Stockholm, Konsumentverket. (in Swedish.)

Danish Labour Market Commission. 2009. Velfæd kræver arbejde [Welfare request work.] Copenhagen, Labour Market Commission. (in Danish.)

De Vaus D. Wells Y. Kending H. Quine S. 2007. Does gradual retirement have better outcomes than abroupt retirement? Results from an Australian panel study. Aging \& Society, 27:667-682. doi:10.1017/So144686X07006228.

Diamond P. 2008. Behavioural economics. Journal of Public Economics, 92:1858-1862.

Disney R. Tanner S. 1999. What can we learn from retirement expectations data?. Working Paper Series No. W99/17. University of Nottingham, The Institute of Fiscal Studies. 
Dittrich D. Büsch V. Micheel F. 2011. Working beyond Retirement Age in Germany: The Employee's Perspective. In Ennals R. Salomon RH. (eds.) Older Workers in a Sustainable Society. Labor, Education \& Society:189202. Frankfurt, Peter Lang Verlag.

Doerpinghaus HI. Feldman DC. 2001. Early Retirement Penalties in Defined Benefit Pension Plans. Journal of Managerial Issues, 13(3):273-288.

Dosman D. Fast J. Chapman SA. Keating N. 2006. Retirement and Productivie Activity in Later Life. Journal of Family and Economic Issues, 27:401419.

Doyle YG. McKee M. Sherriff M. 2012. A model of successful ageing in

British populations. European Journal of Public Health, 22(1):77-76.

Duncan C. 2001. Ageism, early exit and the rationality of age-based discrimination. In Glover I. Branine M. (eds.) Ageism in Work and Employment. England, Ashgate Publishing Ltd.

Dwyer DS. Mitchell OS. 1999. Health problems as determinants of retirement: Are self-rated measures endogenous? Journal of Health Economics, 18:173-193.

Dysting M. 1996. Kurator på akutklinik. [Welfare officer in emergency clinic.] Socialmedicinsk tidskrift, 73(1):33-39. (in Swedish.)

Eklund M. Rahm Hallberg I. 2000. Factors Influencing Job Satisfaction Among Swedish Occupational Therapists in Psychiatric Care.

Scandinavian Journal of Caring Sciences, 14:162-171.

Erber JT. 2010. Aging and Older Adulthood. Second ed. Chichester, John Wiley \& Sons

European Commission. 2010. Demography Report 2010. Directorate-General for Employment, Social Affairs and Inclusion. Eurostat, the Statistical Office of the European Union.

Eurostat. 2010. Work session on demographic projections. Luxembourg, Publications Office of the European Union. http://epp.eurostat.ec.europa.eu/cache/ITY_OFFPUB/KS-RA-10009/EN/KS-RA-10-009-EN.PDF [cited 24 February 2011].

Ewles L. Simnett I. 1992 Promoting Health. A Practical Guide. Harrow, Scutari Press Lth.

Fairclough N. 1992. Discourse and Social Change. Cambridge, Policy Press.

Feldman DC. Beehr TA. 2011. A Three-Phase Model of Retirement Decision Making. American Psychologist, 66(3):193-203.

Friis K. Ekholm O. Hundrup YA. Obel EB. Grønbæk. 2007. Influence of health, lifestyle, working conditions, and sociodemography on early retirement among nurses: The Danish Nurse Cohort Study. Sandinavian Journal of Public Health, 35:23-30. 
Fochsen G. Sjögren K. Josephson M. Lagerström M. 2005. Factors contributing to the decision to leave nursing care: a study among Swedish nursing personnel. Journal of Nursing Management, 13:338-344.

Folkpensionslag Finland. http://www.edilex.fi/kela/sv/lainsaadanto/20070568 (cited 26 June 2012). (in Swedish.)

Forma P. Tuominen E. Väänänen-Tomppo I. 2005. Who wants to continue at work? Finnish pension reform and the future plans of older workers. European Journal of Social Security, 7:227-250.

Furunes T Mykletun R. 2011. Managers' Decision Latitude for Age Management: Do Managers and Employees have the same (implicit) Understanding? In Ennals R. Salomon RH. (eds.) Older Workers in a Sustainable Society. Labor, Education \& Society: 107-116. Frankfurt, Peter Lang Verlag.

Gander P. Signal L. 2008. Who is too old for shift work? Developing better criteria. Chronobiology International, 25(2\&3):199-213.

Gardell B. Gustafsson R. Brandt C. Tillström I. Torbjörn I. 1979. Sjukvård på löpande band. [Health care on a conveyor belt]. Stockholm, Prismas bokförlag. (in Swedish.)

Giannakouris K. 2010. Regional population projections EUROPOP2008: Most EU regions face older population profile in 2030. Eurostat: Population and social conditions, Statistics in focus. http://epp.eurostat.ec.europa.eu/cache/ITY_OFFPUB/KS-SF-10001/EN/KS-SF-10-001-EN.PDF [cited 3 March 2011].

Glover I. Branine M. 2001. Ageism in Work and Employment. England, Ashgate Publishing Ltd.

Goffman E. 1959. The presentation of Self in Everyday Life. New York, Doubleday \& Company, Inc.

Grahn M-L. 2003. Hur ska vi orka till 65? [How will we manage to work until 65?]. Stockholm, Swedish National Institute of Working life. (in Swedish.)

Gueorguieva R. Sindelar JL. Falba TA. Fletcher JM. Keenan P. Wu R. Gallo WT. 2009. The Impact of Occupation on Self-Rated Health: CrossSectional and longitudinal Evidence from the Health and Retirement Survey. Journal of Gerontology: Social Sciences, 64B(1):118-124.

Gurubhagavatula I. Maislin G. Nkwuo JE. Pack AI. 2004. Occupational Screening for Obstructive Sleep Apnoea in Commercial Drivers. American Journal of Respiratory \& Critical Care Medicine, 170:371-376.

Göbel C. Zwick T. 2009. Age and Productivity - Evidence from Linked Employer Employee Data. Centre for European Economic Research No. 09-020. 
Göbel C. Zwick T. 2010. Which Personnel Measures are Effective in Increasing Productivity of Older Workers? Centre for European Economic Research. No. 10-069.

Hagberg B. Rennemark M. 2004. Den åldrande människans psykologi. Ett livsloppsperspektiv. [Phycology of human aging, A life perspective.] Lund, Studentlitteratur. (in Swedish.)

Hall S. 2001. The Spectacle of the "Other". In Wetherell M. Taylor S. Yates S.J. (eds.) Discourse Theory and Practice: 324-344. London, Sage.

Hallberg D. 2007. Äldres arbetsutbud och möjligheter till sysselsättning, en kunskapsöversikt. [Older workers work opportunities and employment possibilities. A literature review.] Ds 2007: 21. Sweden, Ministry of Finance. (in Swedish.)

Hallsten L. 1996. Arbete och psykologiska åldersförändringar. [Work and mental age changes.] In Aronsson G. Kilbom Å. (eds.) Arbete efter 45. Historiska, psykologiska och fysiologiska perspektiv på äldre $\mathrm{i}$ arbetslivet: 133-172. Stockholm, Swedish National Institute of Working life. (in Swedish.)

Hallsten L. Solem PE. 1996. Ålder och arbetsprestation. [Age and work capacity.] In Aronsson G. Kilbom Å. (eds.) Arbete efter 45. Historiska, psykologiska och fysiologiska perspektiv på äldre i arbetslivet: 173-184. Stockholm, Swedish National Institute of Working life. (in Swedish.)

Hank K. 2011. How "Successful"“ Do Older Europeans Age? Findings from SHARE. Journal of Gerontology: Social Science, 66B(2):230-236. doi:10.1093/geronb/gbq089.

Hanson Frieze I. Olson JE. Murrell AJ. 2011. Working Beyond 65: Predictors of Late Retirement for Women and Men MBAs. Journal of Women \& Aging, 23:40-57.

Hao Y. 2008. Productive Activities and Psychological Well-Being Among Older Adults. Journal of Gerontology, 63B(2):64-72.

Harkonmäki K. Martikainen P. Lahelma E. Pitkäniemi J. Halmeenmäki T. Silventoinen K. Rahkonen O. 2009. Intentions to retire, life dissatisfaction and the subsequent risk of disablility retirement. Scandinavien Journal of Public Health, 37:252-259. doi: 10.1177/1403494808100273.

Harkonmäki K. Rahkonen O. Martikainen P. Silventainen K. Lahelma E. 2006. Associations of SF-36 mental health functioning and work and family related factors with intentions to retire early among employees.

Occupational \&Environmental Medicine, 63:558-563.

Hernandez-Peck MC. 2008. Older Farmers: Factors Affecting Their Health and Safety. Centre for Studies in Aging School of Social Work and Human Services, Estern Washington University. 
http://www.cdc.gov/nasd/docs/d001701-d001800/d001760/d001760.pdf Accessed (cited 02 December 2008)

Herzberg F. 1966. Work and the Nature of Man. New York, The World Publishing Company.

Herzberg F. Mausner B. Bloch Snyderman B. 1959. The Motivation to Work. New York, Wiley \& Sons, Inc.

Higgs P. Mein G. Ferrie J. Hyde M. Nazroo J. 2003. Pathways to early retirement: structure and agency in decision-making among British civil servants. Ageing \& Sociey, 23:761-778.

Hirschman AO. 1970. Exit, Voice and Loyalty. Responses to Decline in Firms, Organizations, and States. London: Harvard University Press.

Holliday R. 2010. Ageing and the decline in health. HEALTH, 2(6):615-619.

Holmberg S. Thelin A. Stiernström EL. Svärdsudd K. 2004. Psychosocial factors and low back pain, consultations, and sick leave among farmers and rural referents: a population-based study. Journal of Occupational Environmental Medicine, 46(9):993-8.

Horne JA. Reyner LA. 1995. Sleep related vehicle accidents. British Medicine Journal, 310(4):565-567.

Hornung OP. Danker-Hopfe H. Heuser I. 2005. Age-related change in sleep and memory: Commonalities and interrelationships. Experimental Gerontology, 40:279-285.

Howard ME. Desai AV. Grunstein RR. Hukins C. Armstrong JG. Joffe D. Swann P. Campbell DA. Pierce RJ. 2004. Sleepiness, Sleep-disordered Breathing, and Accident Risk Factors in Commercial Vehicle Drivers. American Journal of Respiratory \& Critical Care Medicine, 170:10141021.

Hult C. Stattin M. 2009. Age, Policy Changes and Work Orientation: Comparing Changes in Commitment to Paid Work in Four European Countries. Population Ageing, 2:101-120.

Hult C. Stattin M. Janlert U. Järvholm B. 2010. Timing of retirement and mortality - A cohort study of Swedish construction workers. Social Science \& Medicin, 70:1480-1486.

Hunter J. 2001. Demographic variables and chronic pain. Clin J Pain, 17:1419.

Härmä M. 2011. Adding more years to the work careers of an aging workforce - what works? Scandinavian Journal of Work, Environment \& Health, 37(6):451-3. doi.org/10.5271/sjweh.3198.

Härmä M. 2012. Is retirement beneficial or harmful to mental health? Scandinavian Journal of Work, Environment \& Health, 38(5):391-392. doi:10.5271/sjweh.3315 
Höög J. 1985. Arbetstillfredsställelse och frånvaro. [Work satisfaction and absence.] Umeå University, Department of Sociology. (in Swedish.)

Höög J. Stattin M. 1995. Förtidspensioneringens utveckling och bakgrund. [The disability pensions development and background.] In Marklund S. (ed.) Rehabilitering i ett samhällsperspektiv. [The societies perspective of rehabilitation.] Lund, Studentlitteratur. (in Swedish.)

Idler EL. Benyamini Y. 1997. Self-rated Health and Mortality: A review of Twenty-Seven Community Studies. Journal of Health and Social Behaviour, 38:21-37.

Ilmarinen J. 1997. Ageing and work - Coping with strength and weaknesses. Scandinavian Journal of Work, Environment \& Health, 23:3-5.

Ilmarinen J. 2003. Promotion of Work Ability during Aging. In Kumashiro M. (ed.) Aging and Work: 23-39. London, Taylor \& Francis.

Ilmarinen J. 2006. Toward a longer working life: Aging and quality of working life in the European Union. Helsinki, Finnish Institute of Occupational Health.

Ilmarinen J. 2012. Promotion active ageing in the workplace. European Agency for Safety and Health at Work.

Hhttp://osha.europa.eu/en/publications/articles/promoting-active-ageingin-the-workplaceH (cited 12 June 2012)

Ilmarinen J. Louhevaara V. 1999. Finn Age - Respect for the aging: Action program to promote health, work ability and well-being of aging workers in 1990-96. Helsinki, Finnish institute of Occupational Health.

Isberg B. 2002. Sjukskrivningsprofil hos sjuksköterskor på

Sahlgrenskasjukhuset år 2002. [Sick absent among nurses on Sahlgrenska hospital in 2002.] Stockholm: Swedish National Institute of Working life. (in Swedish.)

Jensen PH. Juul Møberg R. 2012. Age Management in Danish Companies: What, How and How Much? Nordic Journal of Working Life Studies, 2(3):49-65.

Jokela M. Ferrie JE. Gimeno D. Chandola T. Shipley MJ. Head J. Vahtera J. Westerlund H. Marmot MG. Kivimäki M. 2010. From Midlife to early Old Age. Health trajectories Associated With Retirement. Epidemiology, 21(3):284-290.

Johansson A-K. Olofsson G. 1996. Sjukgymnasternas syn på sin psykosociala arbets-situation och yrkets framtid, samt sjukgymnasters inställning till utbildning och forskning. [Physiotherapists mental work situation, the professions future, and physiotherapists attitude to education and research.] Stockholm, Karolinska Institute. (in Swedish.)

Johansson J. Abrahamsson L. 2007. Lean production and the future of "the good work“". Luleå University of Technology. 
Johansson M. Östergaard S. 1998. Besvär från rörelseorganen hos läkarsekreterare. [Skeleton and locomotive demands among medical secretaries.] Borås, Älvsborgshälsan. (in Swedish.)

Johnston DW. Wang-Sheng L. 2009. Retiring to the good life? The short-term effects of retirement on health. Economic Letters, 103:8-11.

Jones C. Routley V. Tryell G. Ibrahim J. Ozanne- Smith J. 2012. A descriptive analysis of work-related fatal injury in older workers in Australia 20002009. International Journal of Injury Control and Safety Promotion, doi:10.1080/17457300.2012.679001

Järnfelt N. 2010. Education and Longer Working Lives: A longitudinal study on education differences in late exit from working life among older employees in Finland. Helsinki, Finnish Centre for Pension Studies.

Jönsson S. 2005. Client work, job satisfaction and work environment aspects in human service organizations. Lund University, Department of Psychology.

Jönsson S. Tranquist J. Petersson H. 2003: Mellan klient och organisation. Psykosocial arbetsmiljö i arbete med människor. [Between client and organization. Psychosocial work environment within work including people.] Malmö, Swedish National Institute of Working life. (in Swedish.)

Karasek R. Theorell T. 1990. Healthy work - stress, productivity, and the reconstruction of working life. New York, Basic Books.

Karlsson NE. Carstens JM. Gjesdal S. Alexandersson KAE. 2008. Work and Health. Risk factors for disability pension in a population-based cohort of men and women on long-term sick leave in Sweden. European Journal of Public Health. 18(3):224-231.

Karlsson H. Olsson H. 2011. Medelpensionsålder och utträdesålder 2011. [Average retirement age and exit age 2011.] Stockholm, Pensionsmyndigheten. (in Swedish.)

Karpansalo M. Manninen P. Kauhanen J. Lakka T. Salonen JT. 2004. Perceived health as a predictor of early retirement. Scandinavian Journal of Work, Environment \& Health, 30(4):287-292.

Keating N. Marshall J. 1980. The process of Retirement: The Rural Self Employed. The Gerontologiskt, 20(4):437-443.

Kilbom Å. Torgén M. 1996. Fysisk förmåga och hälsa bland äldre i yrkeslivet. [Physical ability and health among older workers.] In Aronsson G. Kilbom Å. (eds.) Arbete efter 45. Historiska, psykologiska och fysiologiska perspektiv på äldre i arbetslivet: 103-132. Stockholm: Swedish National Institute of Working life. (in Swedish.)

Kim S. Feldman DC. 2000. Working in retirement: The antecedents of bridge employment and ist consequences for quality of life in retirement. Academy of Management Journal, 43(6):1195-1210. 
Koolhaas W. van der Klink JJ. Groothoff JW. Brouwner S. 2012. Towards a sustainable healthy working life: association between chronological age, functional age and work outcomes. European Journal of Public Health, 22(3):424-429.

Kristiansen J. Persson R. Björk J. Albin M. Jakobsson K. Östergen P-O. Ardö J. 2011. Work stress, worries and pain interact synergistically with modelled traffic noise on cross-sectional associations with self-reported sleep problems. International Archives of Occupational \& Environmental Health, 84:211-224.

Kulik L. 2001. Marital relations in later adulthood, throughout the retirement process. Ageing \& Society, 21:447-469.

Kubicek B. Korunka C. Hoonakker P. Raymo JM. 2010. Work and Family Charateristics as Predictors of Eary Retirement in Married Men and Women. Research on Aging, 32(4):467-498.

Kvale S. 2001. Den kvalitativa forskningsintervjun. [The qualitative research interview.] Lund, Studentlitteratur. (in Swedish.)

Laaksonen M. Metsä-Simola N. Martikainen P. Pietiläinen O. Rahkonen O. Gould R. Partonen T. Lahelma E. 2012. Trajectories of mental health before and after old-age and disability retirement: a register-based study on purchases of psychotropic drugs. Scandinavian Journal of Work, Environment \& Health, 38(5):409-417. doi.org/10.5271/sjweh.3290.

Laslett P. 1991. A Fresh Map of Life: the Emergence of the Third Age. Cambridge Massachusetts, Harvard University Press.

Lavesson L. Nilsson K. 2011. Naturens betydelse för hälsa och livsstil. [Importance of nature to health and lifestyle.] In Ottosson J. Lundqvist S. Johnsson L. (eds.). Grön Entreprenör: 90-107. Naturupplevelse och hälsa. Swedish University of Agricultural Sciences, Alnarp. (in Swedish.)

Lawoko S. Soares JJF. Nolan P. 2004. Violence towards psychiatric staff: a comparison of gender, job and environmental characteristics in England and Sweden. Work \& Stress, 18(1):39-55.

Leger D. 1994. The cost of sleep -related accidents: a report for the National Commission on Sleep Disorders Research. Sleep, 17:84-93.

Li C-Y. Sung F-C. 1999. A review of the healthy worker effect in occupational epidemiology. Occupational Medicine, 49:225-229. doi:10.1093/occmed/49.4.225.

Lill L. 2007. Att göra etnicitet - inom äldreomsorgen. [Doing etnicity - in elderly care.] Malmö University, Faculty of Odontology. (in Swedish.)

Lindgren G. 1992. Doktorer, systrar, flickor. [Doctors, nurses, girls.] Stockholm, Carlssons förlag. (in Swedish.)

Lindgren G. 1999. Klass, kön och kirurgi. [Class, gender and surgery.] Malmö, Liber. (in Swedish.) 
Lipsky M. 1980. Street level Bureaucracy - Dilemmas of the Individual in Public Services. New York, Russel Sage Foundation.

Marcum JL. Browning SR. Reed DB. Charing RJ. 2011. Determinants of Work Hours Among a Chohort of Male and Feale Farmers 50 years and Older in Kentucky and South Carolina (2002-2005) Journal of Agromedicine, 16:163-173.

Marmot M. 2004. Status syndrome: how your social standing directly affects your health and life expectancy. London, Bloomsbury.

Mather M. 2010. Aging and cognition. Cognitive Science, 1:346-362.

McGoldrick AE. Arrowsmith J. 2001. Discrimination by age: the organizational response. Glover I. \& Branine M. (eds.) Ageism in Work and Employment. England, Ashgate Publishing Ltd.

McLaughlin AC. Sprufera JF. 2011. Aging Farmers Are at Risk for Injuries and Fatalities: How Human-Factors Research and Application Can Help. North Carolina Medical Journal, 72(6):481-483.

Mein G. Higgs P. Ferrie J. Stansfeld SA. 1998. Paradigms of retirement: The importance of health and ageing in the Whitehall II Study. Social Science \& Medicine, 47(4):535-545.

Mein G. Martikainen P. Stansfeld S. Marmot M. 2003. Is retirement good or bad for mental and physical health functioning? Whitehall II longitudinal study of civil servants. Journal of Epidemiol Community Health, 57:4649.

Melin B. Wigaeus Tornqvist E. 2004. Kan psykosocial arbetsmiljö ge smärta och värk i nacke och skuldra? [Can psychosocial work environment cause pain and ache in neck and shoulder?] In Gustafsson R̊. Lundberg I. (eds.) Arbetsliv och hälsa 2004. Stockholm, Libers idéförlag. (in Swedish.)

Michélsen H. Löfvander I. Eliasson G. Schulman A. 1999. Arbetsrelaterad psykisk ohälsa bland personal inom sjukvården. [Work related mental disorder among health care personal.] 1999:6. Stockholm, Yrkesmedicinska enheten. (in Swedish.)

Ministry of Health and Social Affairs. 2011. Efter 65 - inte bara pension. En analys av de äldres ekonomiska situation. Ds 2011:42. [After 65 - not only pension. An analysis of elderly peoples financial situation.] Stockholm, Government Offices of Sweden. (in Swedish.)

Mirowsky J. Ross CE. 2008. Cumulative Advantage and it's Rising Importance. Research on Aging, 30(1):93-122.

Mitchell L. Hawranik P. Strain L. 2002. Age-related physiological Changes: Considerations for older Farmers' Performance of Agricultural Tasks. Winnipeg, Centre of Aging, University of Manitoba, Canada.

Moen P. 1996. A Life Course Perspective on Retirement, Gender and WellBeing. Journal of Occupational Health Psychology, 1(2):131-144. 
Molinié A-F. 2005. Feeling capable of remaining in the same job until retirement? International Congress Series, 1280:112-117.

Mossey JM. Shapir E. 1982. Self-Rated Health: A Predictor of Mortality Among the Elderly. American Journal of Public Health, 72(8):800-808.

Munnell AH. Sass SA. Soto M. 2006. Employer attitudes towards older workers: Survey results. Work Opportunities for Older Americans. An Issue in brief: Series 3. Boston, Center for Retirement Research at Boston College.

Munnell AH. Triest RH. Jivan N. 2004. How do pensions affect Expected and Actual Retirement Ages, CRR WP 2004-27. Boston, Center for Retirement Research at Boston College.

Muto T. Sugisawa H. Kim H. Kobayashi E. Fukaya T. Sugihara Y. Shibata H. 2003. Health status and lifestyles of elderly Japanese workers: In Kumashiro M. (ed.) Aging and Work: 72-84. London, Taylor \& Francis.

Myers JR. Layne LA. Marsh SM. 2009. Injuries and Fatalities to U.S. Farmers and Farm Workers 55 Years and Older. American Journal of Industrial Medicine, 52:185-194

Mykletun R. Furunes T. 2011. The Ageing Workforce Management Programme in Vatenfall AB Nordic, Sweden. In Ennals R. Salomon RH. (eds.) Older Workers in a Sustainable Society. Labor, Education \& Society: 93-106. Frankfurt, Peter Lang Verlag.

Mykletun R. Furunes T. Solem PE. 2012. Managers' Belife about Measures to Retain Senior Workforce. Nordic Journal of Working Life Studies, 2(3):109-127.

Månsson NO. Råstam L. 2001. Self-rated health as a predictor of disability pension and death - A prospective study of middle-aged men. Scand Journal of Public Health, 29: 51-158.

Nawrot TS. Staessen JA. Gardner JP. Abraham A. 2004 Telomere length and possible link to X chromosome. Lancet, 363(14):507-510.

Nilsson K. 2003a. Arbetstillfredsställelse hos äldre läkare och sjuksköterskor. [Work satisfaction among older physician and nurses.] Malmö, Swedish National Institute of Working life. (in Swedish.)

Nilsson K 2003b. Förlängt arbetsliv - En litteraturstudie av faktorer med betydelse för förlängt arbetsliv som alternativ till tidig pensionsavgång. [Extended working life - A literature review on factors important to an extended working life as an alternative to early retirement]. Malmö, Swedish National Institute of Working life. (in Swedish.)

Nilsson K. 2004. Man kan inte klara hur mycket som helst! - Chefens syn på arbetsmiljön och dess betydelse för personalens hälsa inom Försäkringskassan. [You cannot handle too much! - Managers attitude to the work environment and these importance the emplyeds health in 
Swedish Social insurance agency.] Malmö, Swedish National Institute of Working life. (in Swedish.)

Nilsson K. 2005a. Vem kan och vill arbeta till 65 år eller längre? En studie av anställda inom hälso- och sjukvården. [Who can and want to work until 65 years or beyond? A study with employed in health and medical care]. Arbete och hälsa 2005:14. Stockholm, Swedish National Institute of Working life. (in Swedish.)

Nilsson K. 2005b. Pension eller arbetsliv? [Pension or working life?]. Malmö, Swedish National Institute in Working life. (in Swedish.)

Nilsson K. 2006. Äldre medarbetares attityder till ett långt arbetsliv. Skillnader mellan olika yrkesgrupper inom hälso- och sjukvården. [Older workers attitude to an extended working life. Differences between occupations in health and medical care.] Arbetsliv i omvandling 2006:10. Stockholm, Swedish National Institute of Working life. (in Swedish.)

Nilsson K. 2007a. Chefers attityder till äldre medarbetare inom kommunen. [Municipal managers attitude to their older workers] Arbetslivsrapport 2007:4. Stockholm, Swedish National Institute of Working life. (in Swedish)

Nilsson K. 2007b. Kön, arbetsliv och ålderspension. [Gender, working life and old age retirement.] In Kadefors R. (ed.) Den äldre arbetskraften. Stockholm, Swedish National Institute of Working life. (in Swedish) http://www.gu.se/ViewPage!renderDecoratedPage.action?siteNodeId=47 8481\&languageId=100000\&contentId=-1 (cited 201208 02)

Nilsson K. 2007c. Kunskapslabbet i Trelleborg - ett projekt om överföring av erfarenhetskunskap mellan kommun- och landstingsanställda samt mellan generationerna. [The Knowledge lab in Trelleborg - Experience knowledge transition project between generations in health care sectors.] Skriftserie 2007:1. Lund, FoU Skåne. (in Swedish.)

Nilsson K. 2007d. Tid för omsorg?! Personalens arbete i korsdraget mellan måsten, prioriteringar och meningsfullhet inom vård- och omsorg. [Time to care?! Health care workers in draught between musts, priority and meaningfulness.] Skriftserie 2007:3. Lund, FoU Skåne. (in Swedish.)

Nilsson K. 2011a. Attitudes of managers and older employees to each other and the effects on the decision to extended working life. In Ennals R. Salomon RH. (eds.) Older Workers in a Sustainable Society. Labor, Education \& Society: 147-156. Frankfurt, Peter Lang Verlag.

Nilsson K. 2011b. Äldre lantbrukares arbetssituation och hälsa. [Older farmers work situation and health] Rapport 2011:37. Alnarp, Swedish University of Agricultural Sciences. (In Swedish.)

Nilsson K. Pinzke S. 2011. Äldre lantbrukares olycksrisker. [Injury risk among older farmers.] Rapport 2011:22. Sveriges lantbruksuniversitet. Alnarp, Swedish University of Agricultural Sciences. (in Swedish.) 
Nordenfelt L. 1991. Livskvalitet och Hälsa - Teori och kritik. [Quality of life and Health - Theory and criticism.] Falköping, Almqust \& Wiksell. (in Swedish.)

Nordenmark M. Stattin M. 2009. Psychosocial wellbeing and reasons for retirement in Sweden. Ageing \& Society, 29:413-430.

Nordiska socialförsäkringsportalen. http://www.nordsoc.org/sv/Island/Pension/ (cited 26 June 2012) (in Swedish.)

Nowak R. Siwicki JK. Chechlinska M. Markowicz S. 2002. Telomere shorting and atherosclerosis. Lancet, 359:976.

Nylén L. Torgén M. 2002. Under vilka förhållanden vill äldre personer yrkesarbeta? [In which conditions want older people to work?] Stockholm, Swedish National Institute of Working life. Work life report; 2002:2. (in Swedish.)

Odén B. 2012. Äldre genom tiderna. [Older people through the ages.] Stockholm, Carlssons bokförlag. (in Swedish.)

OECD. 2006. Live longer, Work Longer. Paris. OECD.

OECD. 2007. Population pyramids in 2000 and 2050. OECD Statistics Portal: Demography and Population. http://www.oecd.org/dataoecd/52/31/38123085.xls (cited 28 February 2011).

OECD. 2011. Social Indicator. Old age support rate. http://www.oecdilibrary.org/social-issues-migration-health/society-at-a-glance-2011/oldage-support-rate_soc_glance-2011-10-en (cited May 2 2012)

Olsson H. 2002. Den äldre arbetskraften. [The elderly work force.] Stockholm, Statistic Sweden. (in Swedish.)

Oude Hengel K. Blatter BM. Geuskens GA. Kopples LLJ. Bongers PM. 2011. Factors associated with the ability and willingness to continue working until the age of 65 in construction workers. International Archives of Occupational \& Environmental Health, Online first. doi: 10.1007/s00420011-0719-3.

Ozawa M. Lum TY. 2005. Men Who Work at Age 70 or Older. Journal of Gerontological Social Work, 45(4):41-63.

Park J. 2010. Health factors and early retirement among older workers. Statistics Canada. 75-001:5-13.

Park S. Cho S-I. Jang S-N. 2012. Health Conditions Sensitivite to Retirement and Job Los Among Korean Middle-aged and Older Adults. Journal of Preventive Medicine and Public Health, 45(3):188-195.

Persson E. Lexell J. Eklund M. Rivano-Fischer M. 2012. Positive Effects of Musculoskeletal Pain Rehabilitation Program Regardless of Pain Duration or Diagnosis. Physical Medicine and Rehabilitation, 4:355-366. 
Pietiläinen O. Laaksonen M. Rahkonen O. Lahelma E. 2011. Self-rated Health as a Predictor of Disablility Retirement - The Contribution of Ill-Health and Working Conditions. PLoS ONE, 6(9):e25004. doi:10.1371/journal.pone0025004.

Pinzke S. 2003. Changes in working conditions and health among dairy farmers in Southern Sweden. A 14-year follow-up. Annals of Agricultural \& Environmental Medicine, 10:185-195.

Pinzke S. Lundqvist P. 2007. Occupational accidents in Swedish agriculture. Agricultural Engineering Research, 13:159-165.

Pit SW. Shretha R. Schofield D. Passey M. 2010. Health problems and retirement due to ill-health among Australian retirees age 45-64 years. Health Policy, 94:175-181.

Pohjonen T. 2001. Perceived work ability of home care workers in relation to individual and work-related factors in different age groups. Occupational Medicine, 51(3):209-217.

Pingel B. Robertsson H. 1998. Yrkesidentitet i sjukvård, - position, person, kön. [Occupational identity in health care - position, person, gender.] Arbete och hälsa 1998:13. Stockholm, Swedish National Institute of Working life. (in Swedish.)

Quaade T. Engholm G. Johansen AM. Möller H. 2002. Mortality in relation to early retirement in Denmark: a population-based study. Scandinavian Journal of Public Health, 30:216-222.

Reed DB. McKnight RH. Browning SB. Westneat SC. 1998. Farmers who never quit working: Self-reported health conditions in an aging workforce. Second International ICOH Conference on Aging and Work Elsinore: September 14-16, Denmark.

Reed DB. Rayens MK. Winter K. Zhang M. 2008. Health Care Delay of Farmers 50 Years and Older in Kentucky and South Carolina. Journal of Agromedicine, Vol. 13(2).

Rennemark M. 1999. Wellbeing in old age. Life history evalutions, sense of coherence and social networks in relation to health. Lund: Department of Psychology Lund University.

RFV 2001. Arbetsgivares attityder till äldre yrkesverksamma. [Employers' attitudes to older professionals.] Stockholm, National Social Insurance Board (RFV). (in Swedish.)

RFV 2004. Det svenska pensionssystemet. [The Swedish National Pension System.] Ministry of Health and Social Affairs \& National Social Insurance Board (RFV). http://www.regeringen.se/content/1/c4/05/07/aa589a7c.pdf (cited September 30 2011) (in Swedish.) 
Roberts J. Rice N. Jones AM. 2008. Early retirement and inequality in Britain and Gearmany: How important is health? Health, Econometrics and Data Group. HEDG Working Paper 08/27. The University of York.

Roberts J. Rice N. Jones AM. 2010. Early Retirement Among Men in Britain and Germany: How Important is Health? The Geveva Papers, 35:644667. doi:10.1057/gpp.2010.24.

Robinson O. Demetre JD. Corney R. 2010. Personality and retirement: Exploring the links between the Big Five personality trains, reasons for retirement and the experience of being retired. Personality \& Individual Differences, 48:792-797. doi:10.1016/j.paid.2010.01.014.

Roethlisberger FJ. Dicksson J. 1939. Management and the Worker. New York, John Wiley \& Sons.

Räddningsverket. 2007. Olyckor i siffror. En rapport om olycksutvecklingen i Sverige. 2007:7 [Accident in number: The change of accidents in Sweden. 2007:7.] Karlstad, Räddningsverket, Nationellt centrum för lärande från olyckor. (in Swedish.)

Salinsky J. Sackin P. 2004. Hur känns det doktorn? [Doctor how does it feel?] Lund, Studentlitteratur. (in Swedish.)

Salthouse T. 1996. The processing-Speed Theory of Adult Age Differences in Cognition. Psychological Rewiev, 103(3):403-428.

Salthouse T. 2000. Aging and measures of processing speed. Biological Psychology, 54: 35-54.

Saurama L. 2004. Experience of early exit. A comparative study of the reasons for and consequences of early retirement in Finland and Denmark in 1999-2000. Helsinki, Finnish Centre for Pension Studies.

Sauré P. Zoabi H. 2011. Retirement Age Across Countries: The role of Occupations. Social Science Research Network (SSRN).

Hhttp://ssrn.com/abstract=1940452H (cited 9 November 2012)

SCB 2007. Jordbruksföretag och företagare 2007. [Agricultural enterprises and entrepreneurs.] Rapport JO 34 SM 0801

http://www.jordbruksverket.se/webdav/files/SJV/Amnesomraden/Statisti $\mathrm{k} \% 2 \mathrm{C} \% 20 \mathrm{fakta} /$ Foretag\%20och\%20foretagare/JO34/JO34SM081/JO34S M0801.pdf (cited 28 February 2011). (in Swedish.)

SCB 2012. Yrkesregistret med yrkesstatistik. [Occupational register with occupational statistics.] http://www.scb.se/Pages/ProductTables___59071.aspx (cited 9 November 2012). (in Swedish.)

Schnalzenberger M. Schneeweis N. Winter-Ebmer R. Zweimüller M. 2008. Job Quality and Retirement Decisions. In: Bösch-Supan A, et al, editors. Health, Ageing and Retirement in Europe (2004-2007). Starting the Longitudinal Dimension. Mannheim: Mannheim Research Institute for the Economics of Aging (MEA). 
Schuring M. Mackenbach J. Voorham T. Burdorf A. 2011. The effect of reemployment on perceived health. Journal of Epidemiology \& Community Health, 65:639-644.

Seitsamo J. Klockars M. 1997. Aging and changes in health. Scandinavian Journal of Work, Environment \& Health, 23 suppl. 1:27-35.

Siegrist J. Wahrendorf M. Von dem Knesebeck O. Jürges H. Bösch-Supan A. 2007. Quality of work, well-being and intended early retirement of older employees - baseline results from the SHARE. Study. European Journal of Public Health, 17(1):62-68. doi:10.1093/eurpub/ckl084.

Silverstein M. 2008. Meeting the Challenges of an Aging Workforce. American Journal of Industrial Medicine, 51:269-280.

Singh-Manoux A. Gueguen A. Martikainen P. Ferrie J. Marmot M. Shipley M. 2007. Self-Rated Health and Mortality: Short- and Long-Term Associations in the Whitehall II Study. Psychosomatic Medicine, 69:138143.

Sjösten N. Nabi H. Westerlund H. Singh-Manoux A. Dartigues J-F. Goldberg M. Zin M. Oksanen T. Salo P. Pentti J. Kivimäki M. Vahtera J. 2010. Influence of retirement and work stress on headache prevalence: A longitudinal modelling study from GAZEL Cohort Study. Cephalagia, 31(6):696-705.

Smith DB. Moen P. 2011. Retirement Satisfaction for Retirees and Their Spourses. Do Gender and the Retirement Decision-making Process Matter?. Journal of Family Issues, 25(2):262-285.

Social pension Denmark. https://www.retsinformation.dk/Forms/R0710.aspx?id=132869\#K2 (cited 26 June 2012) (in Danish.)

Soidre T. 2005. Vill vi jobba till 65 - eller kanske längre? [Do we want to work until 65 - or maybe longer?] Karlstad University, Arbetsmarknad \& Arbetsliv;11:2. (in Swedish.)

Solem PE. Mykletun R. Mykletun A. 2001. Early exit and motivation to work after 62. The $17^{\text {th }}$ Congress of the International Association of Gerontology, Vancover, Canada.

SOU 2009. Inkluderande arbetsliv. [Inclusive working life.] SOU 2009:93. Stockholm, Government Offices of Sweden. (in Swedish, summary in English).

SOU 2012. Längre liv, längre arbetsliv. [Longer life, longer working life.] 2012:28. Stockholm Government Offices of Sweden. (in Swedish.)

Statens Folkhälsoinstitut. 2008a. Folkhälsoenkät 2007 - Nationella data: Svåra sömbesvär. http://www.fhi.se/templates/Page 12245.aspx (cited 15 January 2008) 
Statens Folkhälsoinstitut. 2008b. Folkhälsoenkät 2007 - Nationella data: Svåra besvär av trötthet. http://www.fhi.se/templates/Page 12244.aspx (cited 15 January 2008)

Stattin M. 1998. Yrke, yrkesförändring och utslagning från arbetsmarknaden. [Occupation, change of occupation and marginalization in labour market.] Umeå: Department of Sociology, Umeå University. (In Swedish.)

Stattin M. 2005. Retirement on grounds of ill health. Occupational \& Environmental Medicine, 62:135-140.

Stiernström EL. Holmberg S. Thelin A. Svärdsudd K. 2001. A prospective study of morbidity and mortality rates among farmers and rural and urban nonfarmers. Journal of Clinical Epidemiology, 54(2):121-6.

Stockholms läns landsting. 2012. Stockholms läns Arbetshälsorapport 2012. [Stockholm County Council Workhealth Report 2012.] Stockholm, Centrum för arbets- och miljömedicin inom Stockholms läns sjukvårdsområde. (in Swedish.)

Strawbridge WJ. Wallhagen MI. 1999. Self-rated health and mortality over three decades. Research on Aging, 21(3):402-416.

Sundberg K. 2002. Analys av arbetsbelastning hos sjukgymnaster. [Analysis of work strain among physiotherapists.] Boden, Bodens Sjukgymnastik och Idrottsrehab. (in Swedish.)

Sundgren Grinups B. Holmer J. Lundberg B. 1996.

Barcelona/Karlstadprojektet. En dokumentation av ansatser och resultat. [The Barcelona/Karlstad project. Documentation of objectives and result.] Karlstad, Högskoletryckeriet. (in Swedish.)

Swedish Board of Agriculture. 2006. The Employed in Agriculture 2005. JO 30 SM 0601. Statistics Sweden.

http://jordbruksverket.se/webdav/files/SJV/Amnesomraden/Statistik, \%20 fakta/Sysselsattning/JO30/JO30SM0601/JO30SM0601_ikortadrag.htm Accessed 10 (cited 28 February 2011). (in Swedish.)

Swedish Board of Agriculture. 2008. Jordbruksstatistik årsbok 2008. [Agricultural Statistics 2008.] Stockholm, Statistics Sweden. (in Swedish.)

Taylor MA. Shore L. 1995. Predictors of Planned Retirement Age: An Application of Beehr's Model. Psychology \& Aging, 10:76-83. doi:10.1037/0882-7974.10.1.76.

Thelander E. 2003. Delaktighet och dialog - på väg mot hållbara arbetsplatser. [Participation and dialogue - toward sustainable workplaces.] Stockholm, Swedish National Institute of Working life.

Thelin A. Höglund S. 1994. Change of occupation and retirement among Swedish farmers and farm workers in relation to those in other occupations. A study of "elimination" from farming during the period 1970-1988. Social Science \& Medicine, 38(1):147-51. 
Thelin A. Holmberg S. 2010. Farmers and retirement: a longitudinal cohort study. Journal of Agromedicine, 15(1):38-46.

Thiele Schwarz U. 2008. Health and ill health in working women - balancing work and recovery. Psykologiska institutionen, Stockholms universitet.

Thunborg C. 1999. Lärande av yrkesidentiteter. En studie av läkare, sjuksköterskor och undersköterskor. [Learning from occupational identity. A study with physicians, nurses and nurse assistants.] Lindköping, Lindköpings universitet, Filosofiska institutionen.

Thomsen S. Soares J. Nolan P. Dellender J. Arnetz B. 1999. Feelings of Professional Fulfilment and Exhaustion in Mental Health Personnel: The Importance of Organisational and Individual Factors. Psychotherapy \& Psychosomatics, 68:157-164.

Torgén M. StenlundC. Ahlberg G. Marklund S. 2001. Ett hållbart arbetsliv för alla åldrar. [A sustainable working life in all ages.] Stockholm, Swedish National Institute of Working life. (in Swedish.)

Thorsen S. Rugulie R. Løngaard K. Borg V. Thielen K. Bjorner JB. 2011. The association between psychosocial work environment, attitudes towards older worers (ageism) and planned retirement. International Archives of Occupational \& Environmental Health, online first. doi:10.1007/s00420211-0689-5.

Tornstam L. 2011. Åldrandets socialpsykologi. [Social Psychology of Aging.] Stockholm, Nordstedts förlag. (in Swedish.)

Trist EL. Bamforth KW. 1951. Some Social and Psychological Consequences of the Longwall Method of Coalgetting. Human Relations 4(1).

Tucker-Seeley RD. Li Y. Subramanian SV. Sorensen G. 2009. Financial Hardship and Mortality among Older Adults Using the 1996-2004 Health and Retirement Study. Annals of Epidemiology, 19(12):850-857.

Tuomi K. Huuntanen P. Nykyri E. Ilmarinen J. 2001. Promotion of work ability, the quality of work and retirement. Occupational Medicine, 51(5):318-324. doi:10.1093/occmed/51.5.318.

Ulfberg J. Carter N. Talbäck M. Edling C. 1996. Excessive Daytime Sleepiness at Work and Subjective Work Performance in the General Population and Among Heavy Snorers and Patients with Obstructive Sleep Apnea. American College of Chest Physicans, 110:659-663.

UNFPA \& HelpAge International. 2012. Ageing in the Twenty-First Century: A Celebration and A Challenge. New York, United Nations Population Fund (UNFPA) \& London, HelpAge International.

Vahtera J. Westerkund H. Hall M. Sjösten N. Kivimäki M. Salo P. Ferrie JE. Jokela M. Pentti J. Sigh-Manoux A. Goldberg M. Zins M. 2009. Effect of Retirement on Sleep Disturbances: the GAZEL Prospective Cohort Study. SLEEP, 32(11):1459-1466. 
Vaillant GE. DiRago AC. Mukamal K. 2006. Natural History of Male

Psychological Health, XV: Retirement Satisfaction. American Journal of

Psychiatry, 163(4):682-688.

Vaillant GE. Mukamal K. 2001. Successful Aging. American Journal of Psychiatry, 158(6):839-847.

Valdes AM. Andrew T. Gardner J P. Kimura M. Oelsner E. Cherkas LF. Aviv A. Spector TD. 2005. Obesity, cigarette smoking and telomere length in women. Lancet, 366: 662 - 664. doi:10.1016/S0140-6736(05)66630-5.

van der Meer MJ. 2008. The sociospatial diversity in the leisure activities of older people in the Netherlands. Journal of Aging Studies, 22:1-12.

van Ours JC. 2009. Will You Still Need Me - When I'm 64?. Institute for the Study of Labour, No. 4264.

van Solinge H. Henkens K. 2009. Living longer, working longer? The impact of subjective life expectancy on retirement intentions and behaviour.

Eurpean Journal of Public Health, 20(1):47-51. doi:10.1093/eurpub/ckp118.

Vendramin P. Valenduc G. 2012. Occupation and ageing at work. An analysis oft he findings oft he fith European Working Conditions Survey. Working paper 2012.9. European Trade Union Institution.

Vercruyssen M. 2003. Lifespan Functional Fitness: Encouraging Human Struggle (Physical Activity) and Warning About the Cost of Technology. In Kumashiro M, (ed.) Aging and Work: 62-71. London: Taylor \& Francis.

Villosio C. Di Pierro D. Giordanengo A. Pasqua P. Richiardi M. 2008. Working conditions of an ageing workforce. European Foundation for the Improvement of Living and Working Conditions.

Voaklander DC. Hartling W. Pickett H. Dimich-Ward H. Brison R. 1999. Work-related mortality among older farmers in Canada. Canadian Family Physician, 45(12):2903-2910.

Volkoff S. 1998. The Statistical Study of the Links Between Age, Work and Health. In: Marquié JC. Cau-Bareille DP. Volkoff S. (eds.) Working with Age. London, Taylor \& Francis.

von Bonsdorff ME. 2009. Intentions of Early Retirement and Continuing to Work Among Middle-aged and Older Employees. University of Jyväkyläl, Jyväskylä Studies in Business and Economics.

von Bonsdorff ME. Kokko K, Seitsamo J. von Bonsdorff MB. Nygård C-H. Ilmarinen J. Rantanen T. 2011. Work strain in midlife and 28-year work ability trajectories. Scandinavian Journal of Work, Environment \& Health, 6:455-463. doi:org/10.5271/sjweh.3177.

Wahrendorf M. Sembajwe G. Zins M. Berkman L. Goldberg M. Siegrist J. 2012. Long-term Effects of Psychsocial Work Stress in Midlife on Health Functioning After Labor Market Exit - Results from the GAZEL Study. 
The Journal of Gerontology. Series B: Psychological Sciences \& Social Sciences, 67(4):471-480.

Wang M. Shultz KS. 2010. Employee Retirement: A Review and Recommendations for Future Investigation. Journal of Management, 36(1):172-206. doi:101177/0149206309347957.

Warr P. 1994. Age and Employment. In Triandis HC. Dunnette M. Hough L. (eds.) Handbook of Industrial and Organizational Psychology. Thousand Oaks, CA: Consulting Psychologist Press, 2nd edition.

Weaver DA. 1994. The work and retirement decision of older women: A literature review. Social Securety Bulletin, 57(1):1-40.

Westerlund H. Kivimäki K. Sing-Manoux A. Melchior M. Ferrie JE. Pentti J. Jokela M. Leineweber C. Goldberg M. Zins M. Vahtera J. 2009. Selfrated health before and after retirement in France (GAZEL): a cohort study. Lancet, 374:1889-1896.

Westerlund H. Vahtera J. Ferrie JE. Singh-Manoux A. Pentti J. Melchior M. Leineweber C. Siegrist J. Goldberg M. Zins M. Kivimäki M. 2010. Effect of retirement on major chronic conditions and fatigue: French GAZEL occupational cohort study. British Medical Journal, 341:c6149. doi.org/10.1136/bmj.c6149

Wetherell M. Taylor S. Yates SJ. 2001. Discourse Theory and Practice. London, SAGE Publication.

Widerberg K. 2002. Kvalitativ forskning i praktiken. [Qualitative research in practise.] Lund, Studentlitteratur.

Wikman A. Marklund S. 2003. Tolkningar av arbetssjuklighetens utveckling i Sverige. [Interpretations for work disease development in Sweden.] In von Otter C. (ed.) Ute och inne i svenskt arbetsliv. Arbetsliv i omvandling, 8:25-56. Stockholm, Swedish National Institute of Working Life. (in Swedish.)

Winter Jørgensen M. Phillips L. 2006. Diskursanalys som teori och metod. [Discourse analysis as theory and method.] Lund, Studentlitteratur.

WHO. 2002. Active Ageing A Policy Framework. Spain: World Health Organisation.

Åkerstedt T. Connor J. Gray A. Kecklund G. 2008. Predicting road crashes from a mathematical model of alertness regulation - The Sleep/Wake Predictor. Accident Analysis \& Prevention, 40:1480-1485.

Åkerstedt T. Kecklund G. Gillberg M. 2007. Sleep and sleepiness in relation to stress and displaced work hours. Physology \& Behavior, 92:250-255.

Östberg H. 1992. Retirement, health and sociological conditions. The department of Community Health Sciences, Lund University.

Östlund B. 2008. The Revival of Research Circles: to meet the needs of modern ageing and third age. Educational Gerontology, (34):4. 


\section{Acknowledgments}

I would like to express my gratitude to all of you who in different ways contributed to completion of this thesis. In particular I would like to thank:

All who participated in the studies. Without your contributions there would be no studies.

For financially supporting the studies and this thesis: Swedish Farmers' Foundation for Agricultural Research (SLF); Department of Work Science, Business Economic and Environmental Psycology, Swedish University of Agricultural Science; Division of Occupational and Environmental Medicine, Lund University; The Royal Swedish Academy of Agriculture and Forestry (SLO-foundation); Centre for Medicine and Technology for Working Life and Society, Lund University (Metalund); Region Skåne.

I want to give an especially great thank you to my supervisors, Associate Professor Lars Rylander, Associate Professor Anna Rignell-Hydbom, Associate Professor Stefan Pinzke and Professor Peter Lundqvist, for their supportive minds, belief in me, excellent guidance and sometime rousing discussions $;$ throughout my $\mathrm{PhD}$ studies.

Maria Albin, Carita Håkansson and Margareta Torgén for inspiration and valuable discussions.

Great thanks to all my terrific colleagues at the Department of Work Science, Business Economics and Environmental Psychology, Swedish University of Agricultural Science (SLU). Lotta Löfqvist, Christina Lunner Kolstrup, Elisabeth von Essen, Sarah Andersson, Mozhgan Zachrison, Catharina Alwall Svennefelt, Lillian Lavesson, Fredrika Månsson, Anna Maria Palsdottir, Sara Spendrup, Johan Ottosson, Mats Gyllin, Sara Kyrö Wissler, Thomas 
Björklund, Bengt Håkansson, Mathilda Annerstedt, Carolin Hägerhäll, Katarina Horn af Rantzien, Christina Heintz, Jörgen Olsson, Wictoria Jogmark, for friendship and interesting scientific and "scientific" discussions.

Great thanks to all my nice and friendly colleagues at the Work and Environmental Medicine, Lund University. Ebba Malmqvist, Kristoffer Mattisson, Ralf Rittner, Zoli Mikoczy, Jonas Björk, Kristina Jakobsson, Kristin Andersson, Karin Källén, Amanda Ode, Hanna Weimann, Lisbeth Prahl, Yulia Lindholm, Gerda Rentschler, Camilla Dahlqvist, Jenny Gremark-Simonsen, Emilie Stroh, for your support, for nice chats and for "glögg".

To all great $\mathrm{PhD}$ students and lecturers at the research courses given by the Faculty of Medicine, Lund University, FALF (Forum för arbetslivsforskning), Metalund and Vårdalinstitutet, for interesting and inspiring discussions and laughs on the courses.

Thank you, my former work mates at the Swedish National Institute of Working Life and Region Skåne for your interesting thoughts and our discussions, which formed the basis for the research questions examined in this thesis.

Anders Thelin and Sara Holmberg for their great help with the participants in Paper IV.

To Mary McAfee for her reading and langue revision.

Thanks mother for your persistence gene.

Most of all I want to thank my dear husband Peter and our precious children Johan, Emma, Elin and Jakob for the happiness you give me and for standing by my side in good times and in bad. Love you!

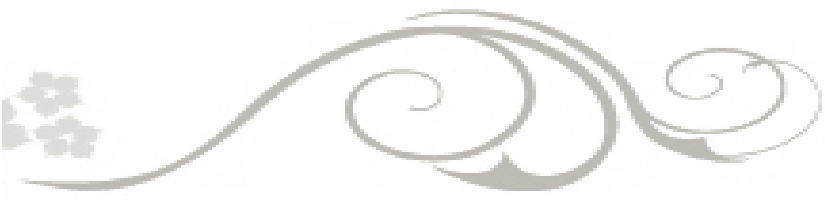




\section{Appendix}

Appendix 1. References to the nine areas identified as important to retirement in Figure 2, 9-12.

Appendix 2. Survey statements used in Papers I and II. 


\subsection{Appendix 1. References to the nine areas}

i) Health - Ahola, et al., 2012; Anderson et al., 1986; Beehr, 1986; Bengtsson \& Nilsson, 2004; Börsch-Supan et al., 2009; Cobb-Clark \& Stillman, 2009; Disney \& Tanner, 1999; Forma et al., 2005; Hallsten, 1996; Holliday, 2010; Hult et al., 2010; Ilmarinen, 2003; Kilbom \& Torgén, 1996; Koolhaas et al., 2012; Laslett, 1991; Nilsson, 2005a; 2006; Nordenmark \& Stattin, 2009; Nylén \& Torgén, 2002; Park, 2010; Park et al., 2012; Pit et al., 2010; Roberts et al., 2008; Schuring et al., 2011; Saurama, 2004; Seitsamo \& Klockars, 1997; Siegerist et al., 2007; Stattin, 1998; 2005; Taylor,\& Shore, 1995; von Bonsdorff, 2009; WHO, 2002.

ii) Economic incentives - Beehr, 1986; Beehr et al., 2000; Bidewell et al., 2006; Börsch-Supan, 2000; Cobb-Clark \& Stillman, 2004; Coppola \& Benita Wilke, 2010; Danish Labour Market Commission, 2009; Diamond, 2008; Doerpinghaus \& Feldman, 2001; Eurostat, 2010; Forma et al., 2005; Roberts et al., 2010; Hank, 2010; Höög \& Stattin, 1995; Ministry of Health and Social Affairs, 2011; Nilsson, 2005a; 2006; OECD, 2006; SOU, 2012; Stattin, 1998; 2005 .

iii) Physical work environment - Bengtsson \& Nilsson, 2004; Grahn, 2003; Gueorguieva et al., 2009; Hallsten \& Solem, 1996; Hernandez-Peck, 2008; Ilmarinen \& Louhevaara, 1999; Jones et al., 2012; Kilbom \& Torgén, 1996; Karlsson et al., 2008; McLaughlin \& Sprufera, 2011; Mitchell et al., 2002; Munnell et al., 2004; Myers et al., 2009; Nilsson, 2003a; 2003b; 2005a; 2005b; 2006; Nilsson \& Pinzke, 2011; OECD, 2006; Pinzke, 2003;Pinzke \& Lundqvist, 2007; Pohjonen, 2001; Reed et al., 1998; Sauré \& Zoabi, 2011; SCB, 2007; Seitsamo \& Klockars, 1997; Silverstein, 2008; Stattin, 2005; Swedish Board of Agriculture, 2006; Villosio et al., 2008; Volkoff 1998; Warr, 1994; Westerlund et al., 2009.

iv) Mental work environment - Andersson-Felé, 2002; Bengtsson \& Nilsson, 2004; Beehr, 1986; Blekesaune \& Solem, 2005; Canivet et al., 2012; Forma et al., 2005; Gardell et al., 1979; Hallsten, 1996; Harkonmäki et al., 2006; Höög, 1985; Höög \& Stattin, 1995; Ilmarinen \& Louhevaara, 1999; Johnston \& Wang-Sheng, 2009; Karasek \& Theorell, 1990; Munnell et al., 2004; Nilsson, 2004; 2005c; 2006; 2007d; Nordenmark \& Stattin, 2009; Park, 2010; Pohjonen, 2001; Seitsamo \& Klockars, 1997; Siegrist et al., 2007; Sjösten et al., 2010; Stattin, 1998; Taylor \& Shore, 1995; Trist \& Bamforth, 1951; Volkoff, 1998; von Bonsdorff, 2009; Warr, 1994; Westerlund et al., 2009. 
v) Work pace and working time - Beehr, 1986; Carter et al., 2003; De Vaus et al., 2007; Forma et al., 2005; Gander \& Signal, 2008; Grahn, 2003; Hallsten, 1996; Howard et al., 2004; Härmä, 2012, Ilmarinen, 2006; Laakssonen et al., 2012; Leger, 1994; Mykletun \& Furunes, 2011; Nilsson, 2005b; 2007a; 2007d; Nordenmark \& Stattin, 2009; Nylén \& Torgén, 2002; Saurama, 2004; Taylor \& Shore, 1995; Thiele Schwarz, 2008; Torgén et al., 2001; Vahtera et al., 2009; von Bonsdorff et al., 2011; Ulfberg et.al., 1996; Westerlund et al., 2010; Åkerstedt et al., 2007.

vi) Attitude to older workers from managers and in the organisation - Artazcoz et al., 2010; Bengtsson \& Nilsson, 2004; Cheung \& Wu, 2012; Doyle et al., 2012; Duncan, 2001; Forma et al., 2005; Furunes \& Mykletun, 2011; Glover \& Branine, 2001; Höög \& Stattin, 1995; Ilmarinen, 2006; 2012; Jensen \& Juul Møberg, 2012; McGoldrick \& Arrowsmith, 2001; Marmot, 2004; Mein et al., 1998; Munnell et al., 2006; Mykletun et al., 2012; Nilsson, 2003b; 2006; 2007a; 2011a; Nordenmark \& Stattin, 2009; Oude Hengel et al., 2011; RFV, 2001; Saurama, 2004; Thorsen et al., 2011; Trist \& Bamforth, 1951; Vercruyssen, 2003; Wikman \& Marklund, 2003.

vii) Competence and possibility for skills development - Abrahamsson et al., 2003; Backes-Gellner et al., 2011; Forma et al., 2005; Grahn, 2003; Hallsten, 1996; Hallsten \& Solhem, 1996; Järnfelt, 2010; Mather, 2010; Mirowsky \& Ross, 2008; Kilbom \& Torgén, 1996; Nilsson, 2005a; 2005b; 2007c; 2007d; 2011b; Nordenmark \& Stattin, 2009; Ozawa \& Lum, 2005; Nylén \& Torgén, 2002; Salthouse, 1996; 2000; Soidre, 2005; Solem et al, 2001; Stattin, 2005; Tuomi et al., 2001; WHO, 2002; Östlund, 2008.

viii) Motivation and work satisfaction - Bengtsson \& Nilsson, 2004; Blauner, 1973; Cobb-Clark \& Stillman, 2009; Doyle et al., 2010; Forma et al., 2005; Gardell et al., 1979; Grahn, 2003; Harkonmäki et al., 2009; Herzberg, 1966; 1959; Higgs et al., 2003; Hirschman, 1970; Hult \& Stattin, 2009; Ilmarinen 1997; Jokela et al., 2010; Karasek \& Theorell, 1990; Kim \& Feldman, 2000; Molinié, 2005; Muto et al., 2003; Nilsson, 2003a; 2004; 2005a; 2005b; 2006; 2007a 2007d; 2011b; Robinson et al., 2010; Roethlisberger \& Dicksson, 1939; Saurama, 2004; Schnalzenberger et al., 2008; Siegrist et al., 2007; Solem et al., 2001; Trist \& Bamforth, 1951; Vaillant et al., 2006; van Solinge \& Henkens, 2009; Wang \& Schultz, 2010.

ix) Family/leisure pursuits and attitude to pension in the surrounding society Beehr et al., 2000; Bengtsson \& Nilsson, 2004; Bidewell et al., 2006; Dosman 
et al., 2006; Doerpinghaus \& Feldman, 2001; Cobb-Clark \& Stillman, 2009; Disney \& Tanner, 1999; Forma et al., 2005; Friis et al., 2007; Grahn, 2003; Hanson Frieze et al., 2011; Hao, 2008; Keating \& Marshall, 1980; Kubicek et al., 2010; Kulik, 2001; Marmot, 2004; Mein et al., 1998; Nilsson, 2005a; 2006, 2007b; 2011b; Nylén \& Torgén, 2002; Ozawa \& Lum, 2005; Smith \& Moen, 2011; van Solinge \& Henkens, 2009; Vendramin \& Valenduc, 2012; Vercruyssen, 2003; Weaver, 1994. 


\subsection{Appendix 2. Working life and retirement}

\section{General questions}

(Answer all questions with only one alternative per question)

1. I am ......

Women

Man

2. I was born in the year $19 . .$.

3. I feel .......

4. My civil status is ......

5. My partner working ......

6. My birthplace is ......
Younger than my chronological age

Older than my chronological age

My chronological age

Married/cohabiting

In a relationship

Single

Yes, part time

Yes, full time

No

Have no partner

In Sweden

In a Nordic country (apart from Sweden)

Within Europe (apart from Nordic area)

Outside Europe

\section{My occupation is}

8. I have worked in my current work place for
16 years or more

11-15 years

6-10 years

5 years or less $\square$
$\square$
$\square$

$\square$

$\square$

$\square$
$\square$
$\square$
$\square$ 
10. I currently work......

$100 \%$

$80-99 \%$

$60-79 \%$

$40-59 \%$

$39 \%$ or less

11. My working hours are......

12. I would prefer to work ......

13. I can work until ......

14. I want to work until ......
Only day time $(07.00-21.30)$

Only night time

Combined day and night time

Combined day and call-out work

Other times

$100 \%$

$80-99 \%$

$60-79 \%$

$40-59 \%$

$39 \%$ or less

Between 55 and 59 years Between 60 and 64 years

65 years

66 years or more

Between 55 and 59 years

Between 60 and 64 years

65 years

66 years or more $\square$

$\square$

$\square$

口

$\square$
$\square$
$\square$
$\square$

$\square$

$\square$

$\square$ 
How do the following statements match your situation?

Specify how the following statements match your situation on a scale from 1-5. Answer all questions, but tick only one option per question

Disagree $\quad$ Agree

15. I hope for an offer from my employer to $1 \square \quad 2 \square \quad 3 \square 4 \square 5 \square$ stop working before age 65

16. I am saving in different ways to make it possible to stop working before age 65

17. My intention is to work beyond age 65 to get a better pension

$1 \square \quad 2 \square \quad 3 \square 4 \square 5 \square$

18. I will probably stop working before age 65 through early age pension (possible from age 61 in Sweden)

19. Shorter working hours would increase my possililities to work to 65 years or beyond

$1 \square \quad 2 \square \quad 3 \square 4 \square 5 \square$

20. I am interested in a combination of part retirement and part time work during the last

$1 \square \quad 2 \square \quad 3 \square 4 \square 5 \square$ years of my working life

21. An extra free day in the week would help me to work up to 65 years or beyond

22. Lowering the working pace would increase my possibilities to work to 65 years or beyond

$1 \square \quad 2 \square \quad 3 \square 4 \square 5 \square$

23. Work is an important part of my life

$1 \square \quad 2 \square \quad 3 \square 4 \square 5 \square$

24. In general I am proud of my work

$1 \square \quad 2 \square \quad 3 \square 4 \square 5 \square$

25. I want to devote more time to leisure activities

$1 \square \quad 2 \square \quad 3 \square 4 \square 5 \square$ and therefore will probably work less in future

26. I will stop working before age 65 when my life partner/close friend stops working

$1 \square \quad 2 \square \quad 3 \square 4 \square 5 \square$

27. I need to work more at home/take care of family and thus will probably work less in the future

$1 \square \quad 2 \square \quad 3 \square 4 \square 5 \square$

28. I am generally satisfied with my daily work

$1 \square \quad 2 \square \quad 3 \square 4 \square 5 \square$ 
33. My current financial situation does not allow me to reduce my working hours

\section{I regard my work as stimulating}

32. I am happy with my current work tasks

34. My financial situation means that I can maintain my current standard if $I$ retire at 65

35. I do not want to decrease my number of working hours even if my financial situation allows that

36. In my circle of acquaintances, it is common to work beyond age 65

37. The common attitude in society is stop working before age 65

38. I have sufficient opportunities to use my professional skills and knowledge in my work

39. I feel that my competence is used in a satisfactory way within the organisation

40. There are special arrangements to adapt the work situation to senior employees at my work place

41. In my profession it is good that older workers stay on for as long as possible

42. My work is too physically demanding for working until 65 or beyond

43. My work environment contains many physically heavi.ey work tasks (e.g. heavy lifting, difficult and monotonous work positions)
$1 \square \quad 2 \square \quad 3 \square \quad 4 \square 5 \square$

$1 \square \quad 2 \square \quad 3 \square \quad 4 \square 5 \square$

$1 \square \quad 2 \square \quad 3 \square \quad 4 \square 5 \square$

1口



1D $2 \square \quad 3 \square \quad 4 \square 5 \square$

1D $2 \square \quad 3 \square \quad 4 \square 5 \square$

ש5

1口

1口 
44. I can mostly manage the physical working demands in my daily work

45. I feel physically worn out

46. Such great changes have occurred in my work situation that I want to stop working before 65 years

47. Worry about new changes in my work situation means that $I$ cannot to work up to 65 years

48. I feel mentally worn out

49. I consider my current health/wellbeing to be good

50. I feel that I get enough rest/relaxation between my working days

51. I seldom feel rested

52. I usually wake up in the middle of the night

53. I have difficulties in getting back to sleep if I wake up in the night

54. I have bad health and have/am probably going to get disability pension before age 65

55. I have a diagnosed disease

56. I have a diagnosed disease caused by my work

57. I believe that this diagnosed disease impedes me in my daily work

58. The working pace in my daily work is too rapid

59. I have sufficient opportunities for pauses in my work

60. I would like to work at a slower pace
$1 \square \quad 2 \square \quad 3 \square \quad 4 \square 5 \square$

$1 \square \quad 2 \square \quad 3 \square \quad 4 \square 5 \square$

$1 \square \quad 2 \square \quad 3 \square \quad 4 \square 5 \square$

1口 $2 \square \quad 3 \square \quad 4 \square 5 \square$

1D $2 \square \quad 3 \square \quad 4 \square 5 \square$

1D $2 \square \quad 3 \square \quad 4 \square 5 \square$

1D $2 \square \quad 3 \square \quad 4 \square 5 \square$

1D $2 \square \quad 3 \square \quad 4 \square 5 \square$

1D $2 \square \quad 3 \square \quad 4 \square 5 \square$

$1 \square \quad 2 \square \quad 3 \square \quad 4 \square 5 \square$

$1 \square \quad 2 \square \quad 3 \square \quad 4 \square 5 \square$

Yes

No

ש5

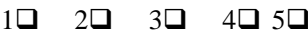

1D $2 \square \quad 3 \square \quad 4 \square 5 \square$

1D $2 \square \quad 3 \square \quad 4 \square 5 \square$

1D $2 \square \quad 3 \square \quad 4 \square 5 \square$ 
61. There are few opportunities for less intensive work for older people at my work place

62. My work is too mentally demanding for me to work to 65 or beyond

$1 \square \quad 2 \square \quad 3 \square \quad 4 \square 5 \square$

63. In my daily work, I can decide when I should take a break

$1 \square \quad 2 \square \quad 3 \square \quad 4 \square 5 \square$

64. I would like greater opportunities to decide how I carry out my work

$1 \square \quad 2 \square \quad 3 \square \quad 4 \square 5 \square$

65. I would like to have more control over my daily work

66. It is common for work to pile up to the extent that I feel frustrated

67. I place too high demands on myself in my work

$1 \square \quad 2 \square \quad 3 \square \quad 4 \square 5 \square$

68. Staff shortages mean that I cannot manage my work in the way I would like

$1 \square \quad 2 \square \quad 3 \square \quad 4 \square 5 \square$

69. I am able to carry out the tasks I have planned during my working day

$1 \square \quad 2 \square \quad 3 \square \quad 4 \square 5 \square$

$1 \square \quad 2 \square \quad 3 \square \quad 4 \square 5 \square$

$1 \square \quad 2 \square \quad 3 \square \quad 4 \square 5 \square$

70. The managers' attitude to senior employees is positive at my work place

$1 \square \quad 2 \square \quad 3 \square \quad 4 \square 5 \square$

71. The attitude to senior employees is generally positive at my work place

$1 \square \quad 2 \square \quad 3 \square \quad 4 \square 5 \square$

72. I feel discriminated against in my work place because of my age

$1 \square \quad 2 \square \quad 3 \square \quad 4 \square 5 \square$

73. I am satisfied with my present work situation

$1 \square \quad 2 \square \quad 3 \square \quad 4 \square 5 \square$

74. My immediate boss is interested in my health/ wellbeing

1D $2 \square \quad 3 \square \quad 4 \square 5 \square$

75. I am unsure whether my competence is sufficient for me to work to 65 years or beyond

$1 \square \quad 2 \square \quad 3 \square \quad 4 \square 5 \square$

76. I am unable to learn new things because of my age

$1 \square \quad 2 \square \quad 3 \square \quad 4 \square 5 \square$ 
77. I have sufficient opportunities to take part in further training

78. I consider that due to my age, I am given fewer opportunities to take part in further training

79. Due to my age, I am given fewer offers to take part in projects at my work place

80. Due to my age I get fewer possibilities to receive supervision
$1 \square \quad 2 \square \quad 3 \square \quad 4 \square 5 \square$

$1 \square \quad 2 \square \quad 3 \square \quad 4 \square 5 \square$

1口 $2 \square \quad 3 \square \quad 4 \square 5 \square$

1口 $2 \square \quad 3 \square \quad 4 \square 5 \square$ 
